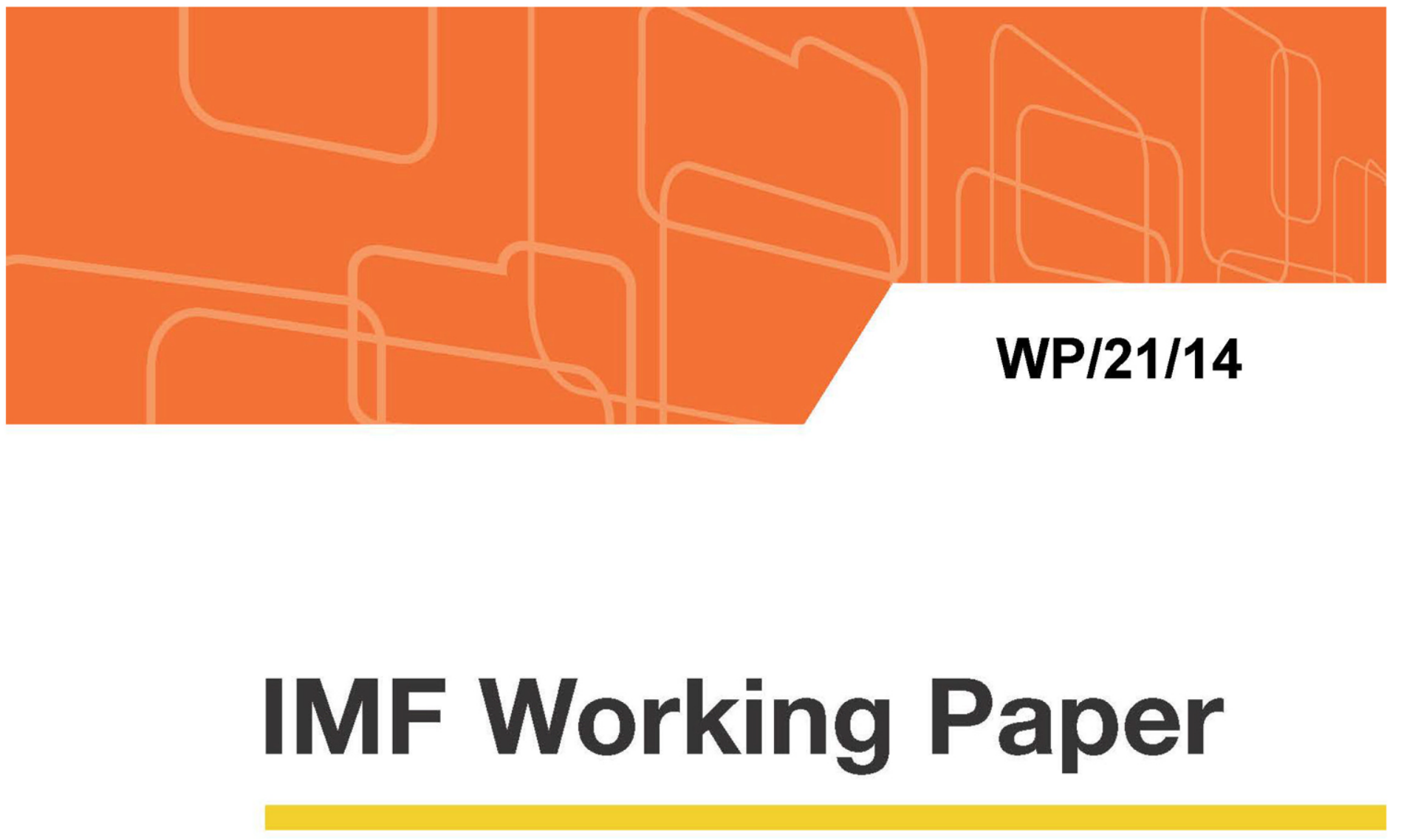

\title{
Unconventional Monetary Policies in Emerging Markets and Frontier Countries
}

by Chiara Fratto, Brendan Harnoys Vannier, Borislava Mircheva, David de Padua, and Hélène Poirson

IMF Working Papers describe research in progress by the author(s) and are published to elicit comments and to encourage debate. The views expressed in IMF Working Papers are those of the author(s) and do not necessarily represent the views of the IMF, its Executive Board, or IMF management. 


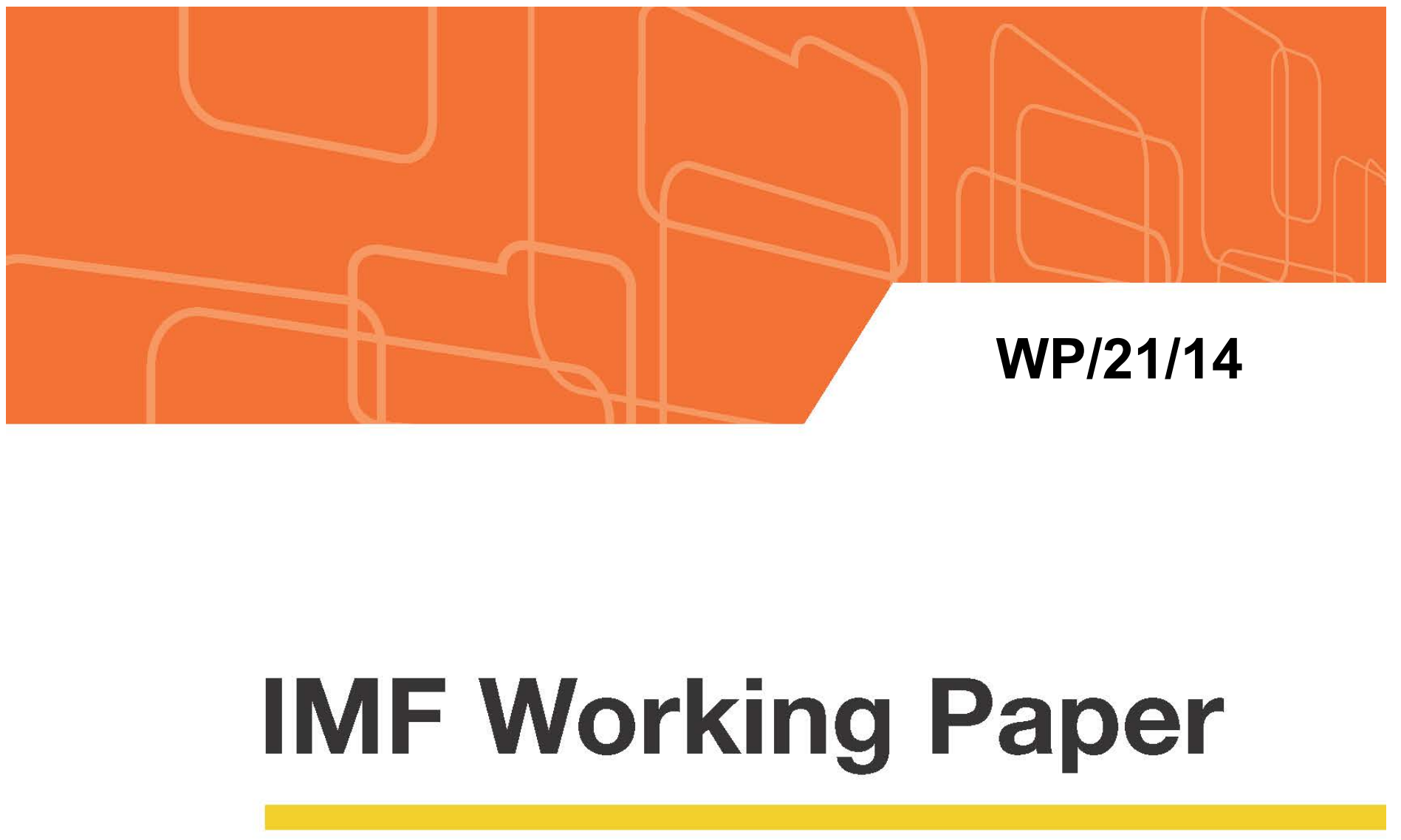

\section{Unconventional Monetary Policies in Emerging Markets and Frontier Countries}

by Chiara Fratto, Brendan Harnoys Vannier, Borislava Mircheva, David de Padua, and Hélène Poirson

IMF Working Papers describe research in progress by the author(s) and are published to elicit comments and to encourage debate. The views expressed in IMF Working Papers are those of the author(s) and do not necessarily represent the views of the IMF, its Executive Board, or IMF management. 


\title{
IMF Working Paper
}

Strategy, Policy, and Review Department

\section{Unconventional Monetary Policies in Emerging Markets and Frontier Countries \\ Prepared by Chiara Fratto, Brendan Harnoys Vannier, Borislava Mircheva, David de Padua, and Hélène Poirson}

Authorized for distribution by Rupa Duttagupta

January 2021

IMF Working Papers describe research in progress by the author(s) and are published to elicit comments and to encourage debate. The views expressed in IMF Working Papers are those of the author(s) and do not necessarily represent the views of the IMF, its Executive Board, or IMF management.

\begin{abstract}
The COVID-19 crisis induced an unprecedented launch of unconventional monetary policy through asset purchase programs (APPs) by emerging market and developing economies. This paper presents a new dataset of APP announcements and implementation from March until August 2020 for 27 emerging markets and 8 small advanced economies. APPs' effects on bond yields, exchange rates, equities, and debt spreads are estimated using different methodologies. The results confirm that APPs were successful in significantly reducing bond yields in EMDEs, and these effects were stronger than those of policy rate cuts, suggesting that such UMP could be important tools for EMDEs during financial market stress.
\end{abstract}

JEL Classification Numbers: E52, E58, E65, G12, G15

Keywords: Unconventional monetary policy; emerging markets; COVID-19; exchange rates; local currency bond markets.

Author's E-Mail Addresses: cfratto@imf.org; bmircheva@imf.org; ddepadua@imf.org; hpoirson@imf.org; brendan.vannier@psemail.eu 


\section{Contents}

Abstract

I. Introduction

II. Motivation for APPs and Previous Findings on Effectiveness

A. Motivation for APPs in EMDEs

B. Transmission Channels from Economic Theory __ 9

C. Effectiveness Results from the Literature __

III. A New Database on UMP in EMDEs _ 11

A. Timeline of APP Announcements ___ 14

B. Implementation

C. Key Features of the APPs___

IV. Effectiveness of UMP Measures in EMs __

V. Conclusions _ $\quad 37$

Figures

1. Stress in Financial Markets, January-July 2020

2. Policy Rate and Public Debt Levels Pre-Crisis in EMDEs___

3. CMP and UMP Transmission to the Economy ___ 9

4. Number of EMDEs Announcing APP ___ 14

5. High CB Transparency __

6. Size of Announced and Realized CB Interventions ___ 17

7. Implementation of APPs Over Time___

8. Realized Size of Interventions

9. Stated Objective of APP Announcements

10. Asset Purchase Programs by Primary vs. Secondary Markets ___

11. Quantity-based Programs Prevail ___ 24

12. Maturity of the Securities Purchased under the APPs __ 25

13. Distribution of the Information in APP Announcement __ 26

14. 10-Year Bond Yield and FX Results __

15. Analytical Results

16. Results Patterns for the 10-Year Bond Yield __ $\underline{36}$

\section{Tables}

1. Availability of Transaction Data 16

2. APP Stated Objectives and Other Policy Measure __ 21

3. Policy Measures Introduced by CBs on the Same Day as APP Announcements___ 22

4. Summary of Asset Purchase Program

$\underline{27}$

\section{Annexes}

I. Structure of the Database $\underline{39}$

II. Details on Taxonomy of Objectives

42


III. Tables with Econometric Results $\underline{56}$

IV. Event Study with Controls and a Panel Regression

V. Literature Review

VI. References 70 


\section{INTRODUCTION ${ }^{1}$}

Even before experiencing their own outbreaks of COVID-19, emerging markets and developing economies (EMDEs) were affected adversely by the economic and financial fallout of the pandemic in March 2020. A marked increase in global investors' risk aversion combined with lower commodity prices translated into a rise in local currency bond yields, capital outflows, and sharp currency depreciations. EMDEs responded to the COVID-19 crisis with a combination of conventional and unconventional measures. In particular, EMDEs introduced their first unconventional monetary policy (UMP) measures in the form of asset purchase programs (APPs), similar to those used by advanced economies (AEs) during the global financial crisis (GFC). ${ }^{2}$

In contrast to small open AEs (Sweden, Switzerland) during the GFC, which deployed UMP at or near the effective lower bound in the context of capital inflows and exchange rate appreciation, most EMDEs in our sample had policy rates above zero and faced external pressures when they launched APPs. In a majority of cases, the programs aimed at affecting the sovereign yield curve, easing stress, and bolstering liquidity of the targeted financial markets. By stabilizing the sovereign secondary bond market and easing broader financial conditions, the APPs improved funding conditions for governments; however, only about a quarter of the EMDE programs (and less than a fifth of small open AE programs) announced support for pandemic-related fiscal needs as a main objective.

While the empirical literature evaluating the effects of UMP in AEs is extensive, and focuses on both financial factors (e.g., term premia) and macro factors (e.g., output and inflation expectations) few studies exist on the effectiveness of UMP in EMDEs - reflecting in part the novelty of these measures. The existing studies focus on the effects of UMP on select financial market variables (e.g., long-term bond yields and exchange rates), and do not explore effects on other financial market variables or second-round effects on related markets. For example, Arslan et al (2020) — using an event study approach for 13 EMs - find that central bank bond purchases on average reduced benchmark (long-term) bond yields in a significant and persistent manner and interrupted depreciation trends. The results are confirmed by panel regressions controlling for confounding factors. Other studies, using somewhat different samples, suggest greater effects of EM APP policy announcements on

\footnotetext{
${ }^{1}$ The authors gratefully acknowledge the useful discussions and suggestions by Rupa Duttagupta, Petya Koeva Brooks, participants of the EM Forum, the authors of Chapter 2 of the IMF's October 2020 Global Financial Stability Report, and comments from the ED offices representing the countries in the sample.

${ }^{2}$ All programs for EMs were newly announced during the COVID-19 crisis, except Indonesia, where it was an expansion of a pre-existing program. During and after the GFC, AEs introduced four main types of unconventional measures: (i) negative interest rate policies, (ii) lending operations or credit policies, where central banks expand their liquidity facilities to support credit flows to the private sector, (iii) large-scale asset purchase programs to address market dysfunctionalities that impaired the transmission channels of monetary policy and/or lower long term bond yields and ease broad financial conditions, and (iv) forward guidance.
} 
sovereign bond yields than in AEs (Hartley and Rebucci (2020)), and that the effect on the exchange rate is relatively small or insignificant (International Monetary Fund (2020)).

Against this background, this paper first develops a novel and extensive database of APP announcements and implementation in EMDEs. The database aims at illustrating the recent experience with such UMP schemes in EMDEs, including their objectives and modalities, and at helping to draw some initial lessons from these policy experiments. Specifically, the database contains recent COVID19-related UMP measures for 27 EMDEs, highlighting different characteristics including: (i) the nature of the program - purpose, size, targeted market, etc.; (ii) whether the announcement were made jointly with other authorities or coincided with other central bank policy announcements; and (iii) transactions data where publicly available. The same information is also collected for 8 small AEs, for comparison.

The information collected in the database on UMP suggests that a number of countries carried out several APPs during the period under consideration (January-August 2020), or tweaked their programs, with programs exhibiting different characteristics depending on the objective. Most of the interventions aimed at boosting confidence and improving market functioning, and targeted the government bond market, although a few countries (BEAC, Brazil, Chile, Ethiopia, Hungary, Israel, Korea, Mauritius, and Norway) aimed at the corporate or bank bond market. Egypt is the only country that purchased equities. The size of the programs in EMDEs was comparable to that of AEs in our sample. About two thirds of these programs were quantity-based (fixed or maximum amount of purchases). Examples include Bolivia, Ethiopia, Ghana, Iceland, India, Mauritius, Mexico, New Zealand, Norway, and Thailand. Other programs were also quantity-based, but more flexible, with purchase amounts calibrated to market conditions and/or the economic and inflation outlook (e.g., Angola, Canada, Colombia, Costa Rica, and Hungary). Except for Chile (price-based APP targeting bank bonds), none of the programs were price-based.

Building and expanding on existing studies, we use the database to empirically analyze the effects of these APPs on financial market variables for 15 emerging markets and 8 small AEs. First, we look at the distribution of sovereign bond yields and exchange rates, following previous studies; and also at the distribution of equity prices, corporate bond yields, and EMBI spreads. For each variable and country, we investigate whether there is a different impact response one, two, and three days following announcements. These effects are also estimated for conventional monetary policy actions for comparison. Second, we use countryspecific regressions to investigate whether other policies announced at the same time as the APP, external factors, and the COVID-19 pandemic's impact on activity alter the impact of the announcements. The results help us identify the main channels of impact as well as whether the effect of UMP is different from that of conventional policy easing. Finally, we test whether the main findings hold when we employ a panel regression, controlling for various factors. The analysis covers the period January through August of 2020. 
The empirical results for EMDEs confirm a negative and statistically significant multi-day effect on bond yields. However, the magnitude and persistence depend on the focus of the APP, i.e. whether the program was quantity- or price-based as well as whether it involved purchases of government bonds or private securities, or both. The results still hold when we exclude APP announcements that coincide with policy rate cuts as well as when the various controls are added and in a panel regression setting. Similarly, conventional monetary policy measures (policy rate cut announcements) have a negative and statistically significant multiday effect on bond yields across the different maturities but of a smaller magnitude than that of APP announcements. For AEs, the results are broadly consistent with the findings in the literature.

This paper is organized as follows. Section II provides a brief overview of the motivation for the use of APPs by EMDEs and discusses their channels of transmission and findings in the literature on their effectiveness. Section III mentions the main elements of the database while section IV provides some empirical findings on the effectiveness of APP announcements. Section V concludes.

\section{Motivation for APPs ANd Previous Findings on EFFEctiveness}

This section discusses conditions facing EMDEs and small AEs at the onset of the COVID outbreak, that prompted the deployment of UMP tools, followed by a discussion of the theoretical channels of transmission, and a summary of the literature findings on effectiveness of such unconventional measures.

\section{A. Motivation for APPs in EMDEs ${ }^{3}$}

As the COVID pandemic intensified with a corresponding rise in investor risk aversion, a number of countries in our sample faced pressures. Specifically, Figure 1 shows, for 14 EMDEs and 7 small AEs, the number of markets facing large fluctuations of the 10-year government bond yield and the exchange rate. The number of countries facing stress in both markets increased sharply at the beginning of March. Shortly after stress peaked, in midMarch, the monetary authorities of many of those economies started announcing APPs.

\footnotetext{
${ }^{3}$ The universe of countries discussed in this section comprises 27 EMDEs and 8 small AEs, which deployed UMP tools between January and August 2020. However, the empirical analysis is constrained at times to smaller sub-samples based on data availability.
} 


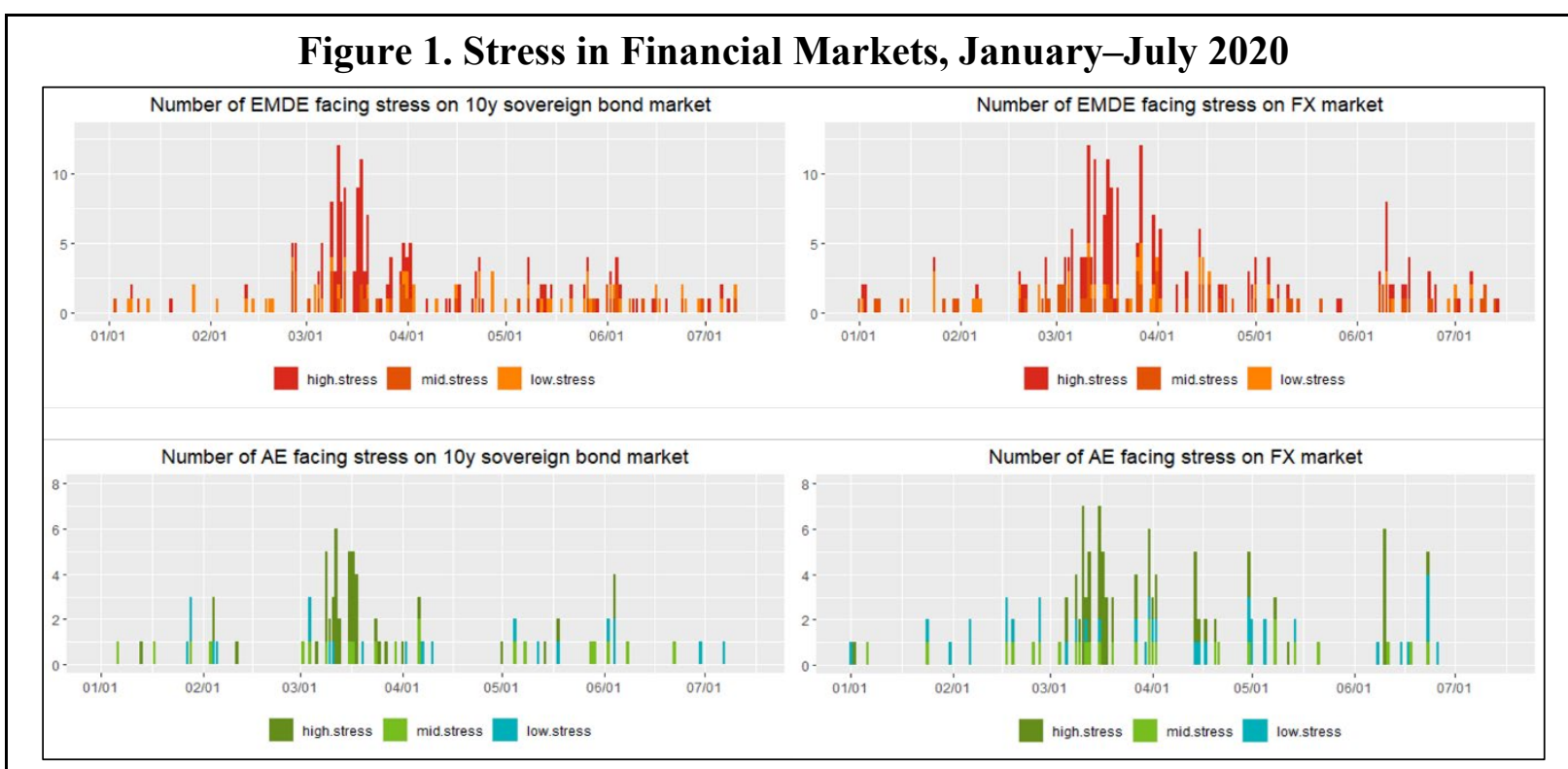

Note: A market is defined as highly stressed when the 1-day price change is in the tail of the distribution (2.58 times the historical standard deviation above the historical average, computed over 2017-2019). Thresholds for mid and low stress are equal to 1.96 and 1.64 , respectively.

Sources: Thomson Reuters and IMF staff calculations.

Overall, EMDEs in our sample started announcing UMP measures even while most of them still had room for policy rate cuts, and relatively low public debt levels. Figure 2 (left panel) shows policy rates for 24 EMDEs at the beginning of March 2020. The countries that announced APPs are represented in orange. All countries faced inflation close to or above target except for Thailand. The same countries except India, Hungary, and South Africa entered the crisis with relatively low public debt levels - similar to the majority of EMDEsand announced fiscal easing measures in response to the COVID-19 shock (Figure 2, right panel).

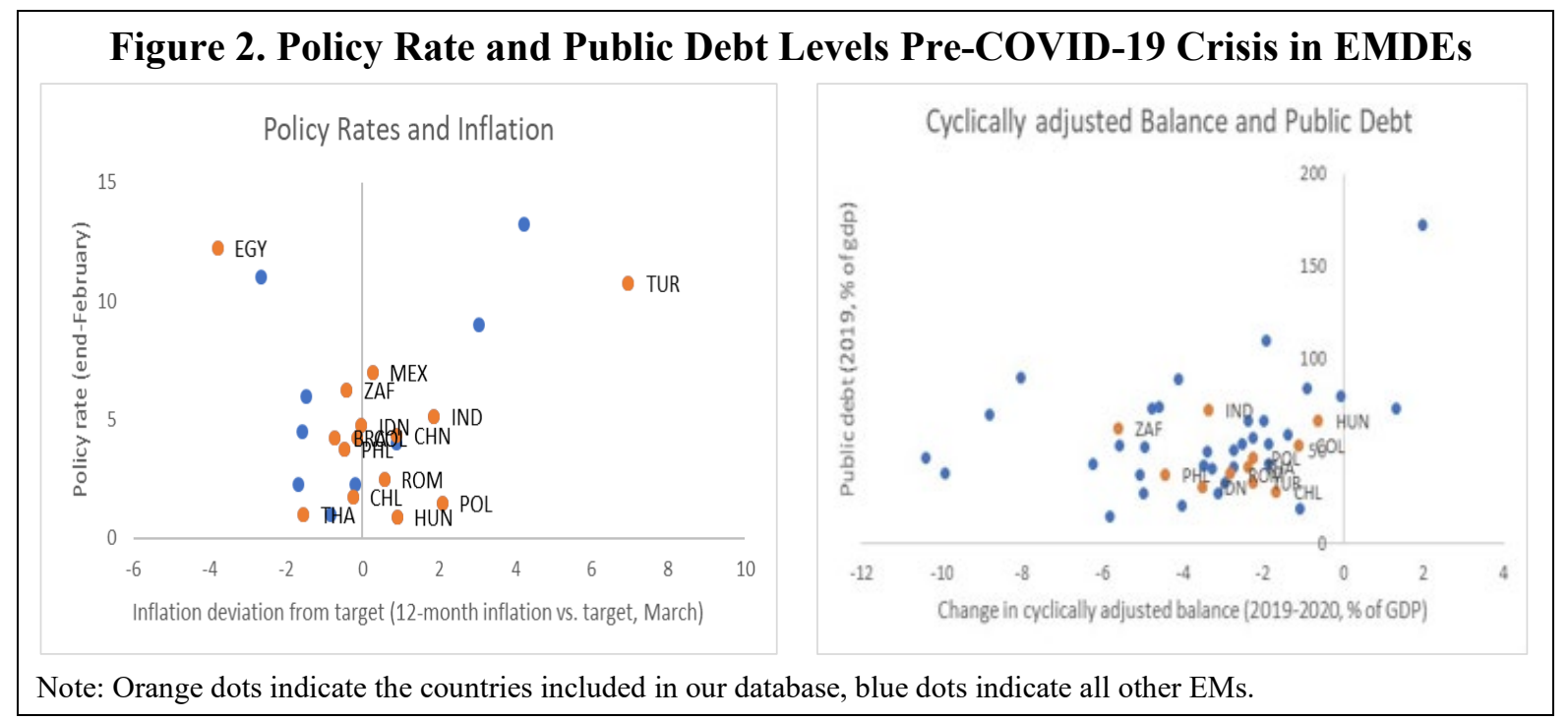




\section{B. Transmission Channels from Economic Theory}

In normal times, when the central bank (CB) implements conventional monetary policy (CMP), changes in the policy rate affect prices. Consequently, financial market participants rebalance their asset portfolio, thus diffusing the effect of the CMP throughout the economy. However, as the COVID19 pandemic hit the world economy, financial markets participants, fearing uncertainty, demanded higher risk premia or fled some markets altogether. This behavior impaired the normal functioning of markets and hindered the transmission mechanism of monetary policy, preventing CMP's intended effect on the aggregate economy. Figure 3 offers an illustration of the theoretical transmission of CMP and UMP (in the form of APPs) on the aggregate economy.

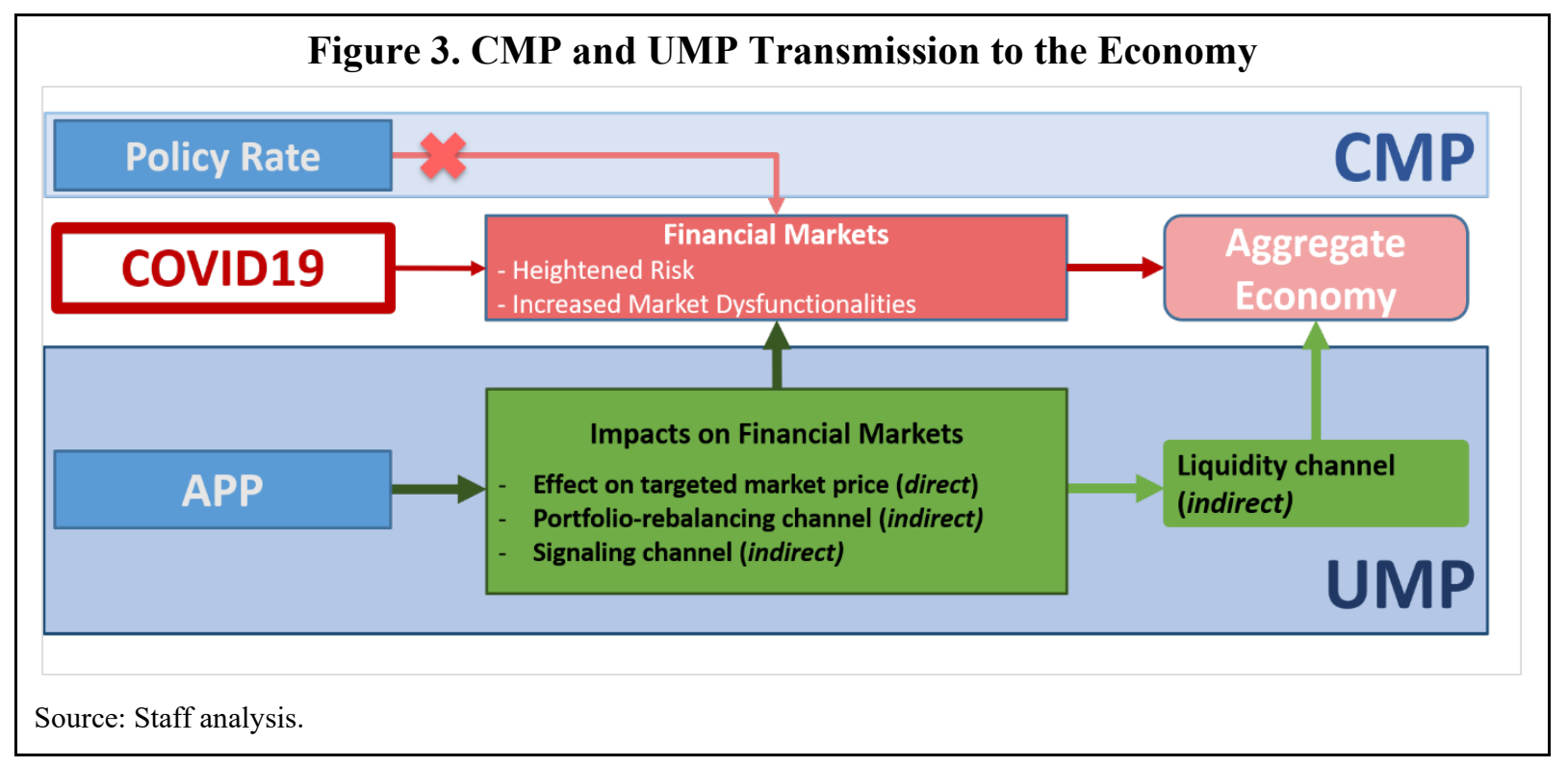

EMDEs introduced APPs to offset financial markets' impairments and/or provide direct support to the economy. Based on the experience of AEs, the literature has identified five main mechanisms through which these measures impact the economic and financial environment. One of these channels is direct. Specifically, as APPs entail a change in the liquidity available on the targeted market, the equilibrium price will need to adjust to the new supply and demand conditions. The other four channels of APP transmission are indirect. The two most prominent ones are the portfolio-rebalancing and signaling channels. Through the portfolio-rebalancing channel, market participants who benefit from the intervention reallocate newly found liquidity across their asset portfolio. If markets are well interconnected, the initial impact can spill over and ease liquidity pressures in other financial markets. Through the signaling channel, as CBs announce APPs, they also signal and clarify their objectives to market participants. Given the novelty of most APPs, these announcements surprise financial markets and the discussion or commitment to future interventions by the CB helps coordinate agents' expectations about future short-term interest rates in uncertain times. Both channels affect long-term interest rates. 
APPs may also lead to increased liquidity and to exchange rate depreciation. Through the liquidity channel, APPs affect the economy indirectly when banks and credit establishments see their liquidity constraints reduced and as a result increase credit supply. To the extent that asset purchases have contributed to a change in interest rate differentials, or that they targeted foreign-currency denominated assets, an exchange rate channel of UMP can also be observed. The exchange rate repercussions of UMP in turn can affect its effectiveness, especially in EMDEs where exchange rate fluctuations are a primary source of volatility and vulnerability. If this exchange rate channel is strong, the cost of funding for domestic participants might not fall as expected, thus countering the initial impact of the program. ${ }^{4}$

With these transmission channels in mind, the impact and effectiveness of APPs might differ across countries. This may be due to underlying structural features. For example, if the CB is more credible or if there is a larger foreign investor participation in the local currency bond market, the confidence-restoring signaling effect of the announcement will be stronger. If a country's financial markets are more interconnected, the portfolio-rebalancing channel might be more efficient. In financial markets that are more exposed to foreign participants, the exchange rate channel could be of sizable importance.

\section{Effectiveness Results from the Literature}

Bhattarai and Neely (2020) provide an extensive overview of the literature on effectiveness of UMP, mostly focusing on AEs. Therefore, this section only mentions a few key findings from previous research. In a first strand of the literature, the majority of the findings- based on the use of event study methodologies - confirm that UMP influenced asset prices and risk premia as would be expected. A number of studies illustrate this for the US (Gagnon et al (2011), Vissing-Jorgensen and Krishnamurthy (2011), and Swanson (2011)), showing a decrease in the 10-year bond yield of about 0.2 percent after the announcement of the measure. Briciu and Lis (2015) look at seven balance sheet policies launched by the ECB between 2008 and 2015 and find a cumulative two-day effect on the 10-year bond yield ranging from 33 to $-17 \mathrm{bps}$. Roache and Rousset (2013) use an event study as well to show that "tail risk" diminishes in the immediate aftermath of UMP events, particularly downside left tail risk.

In a second strand of the literature on effects of UMP in AEs, calibrated modeling and vector auto-regressive (VAR) exercises are used to show that these unconventional macroeconomic policies improved macroeconomic outcomes as well. A number of studies illustrate this relationship for advanced economies (MacDonald and Popiel (2017), Gambacorta et al (2013), Weale and Wieladek (2016)). The effects range from 0.25 to 0.62 percent for estimates of the peak responses of real GDP and inflation. As the macroeconomic effects are difficult to disentangle between conventional and unconventional periods, $\mathrm{Wu}$ and $\mathrm{Xia}$

\footnotetext{
${ }^{4}$ At the same time, the weakening local currency should stimulate exports and have an offsetting positive effect on the economic outlook and inflation.
} 
(2016) use their shadow rate to show that macroeconomic effects of an unanticipated change in the policy instrument are similar to the pre-ELB period.

Only a few studies focus on the impact of UMP in EMs. Hartley and Rebucci (2020) and Arslan et al. (2020), both based on event study approaches, find that on average, bond purchases reduced benchmark bond yields. Hartley and Rebucci (2020) find an average response of -0.28 to -0.43 percent of the 10 -year bond yield in EMs, which is higher than that for developed markets (-0.11 to -0.14 percent). In addition, Arslan et al (2020) find that APPs appear to have shored up the exchange rate on average, although the results vary by countries. Some of the event studies in the literature also use control variables (Rai and Suchanek (2014); Falagiarda, McQuade, and Tirpak (2015); and IMF (2016)) to investigate the effectiveness of UMP. They find that, in general, the portfolio rebalancing and signaling channels play a key role. Last, Sever et al. (2020) builds on the literature by expanding the country sample, accounting for multiple APP announcements for each country, and introducing controls for cost of borrowing and various global factors. The results show that APP announcements had a significant impact on bond yields and helped turn around sentiment but did not lead to depreciation of emerging market currencies.

\section{A New Database ON UMP In EMDES}

This paper presents a new and detailed database on recent UMP announcements in emerging market and developing economies and the realized transactions data (when available). ${ }^{5}$ Specifically, we collect detailed information on 50 asset purchases programs announced between March and August 2020 in a total of 27 EMDEs and 8 small advanced economies (the latter, included as a benchmark for comparison). Table 4 includes the list of countries in the database and summary statistics.

The initial sample of countries has been selected from the policy announcements recorded as APP in the IMF Central Bank Intervention Database (CBID), the Yale tracker, and the IMF COVID policy tracker. ${ }^{6} \mathrm{We}$ drew on central bank press releases as the primary source of information for the database, including for information on implementation so far. ${ }^{7}$

\footnotetext{
${ }^{5}$ We included realized transaction data only when such information was publicly available and clearly linked to the asset purchase program announced. In the case of Philippines, purchases of government securities under the follow-up of the repurchase agreement program in the secondary market by the CB (announcement of April $\left.10^{\text {th }}, 2020\right)$ are excluded from the database.

${ }^{6}$ Even though the paper focuses on CB interventions, several reasons justify not relying solely on the CBID: (i) some announcements were made jointly and announced, for example, by the Ministry of Finance; (ii) in some cases, the programs were directly announced by other authorities (Presidential decrees, Prime Minister Statement); (iii) finally in some cases the passing of a law allowing the CB to purchase assets served as the first mention to market participants of this shift in mandate of the CB.

${ }^{7}$ For Egypt and Ethiopia, the CB communication did not discuss the introduction of the APP. We collected instead information from the news.
} 
The dataset consolidates the existing information dispersed in several other databases and broadens their coverage to a longer time period and more countries. In addition, it seeks to extract and present the real-time flow of information that central banks provide to market participants when they announce, augment, change, or implement APPs. To this effect, the dataset includes: (i) both the initial program announcement and all subsequent announcements; (ii) implementation dates and related published information (to allow separation of announcement effects from implementation effects); (iii) broader time and country coverage; and (iv) the information provided by the central banks and/or other authorities at the time of the announcements and implementation. Specifically, we identify the CB's communication style and how the information is shared in subsequent announcements, whether the announcement was made jointly with other national authorities and was part of a policy package, etc. ${ }^{8}$

The database covers all CB purchases (or sales) of private and/or public securities on the primary or secondary markets. Such APPs often result in permanent changes to the CB's balance sheet. However, the database also includes information on measures such as (i) twist operations to purchase long-term and sell short-term government securities that do not result in expansion of CB balance sheets, but affect the yield curve (Colombia, India, and Mexico), (ii) the establishment of special purpose vehicles (Korea, Mauritius) or investment funds (Norway ${ }^{9}$, Thailand ${ }^{10}$ ) to purchase equities and other private securities, (iii) direct monetary financing of the government (one-off contribution made by the Bank of Mauritius to the government), and (iv) purchase of loans to SMEs by the People's Bank of China.

Overall, this new dataset allows for much more granular and operational analysis of the types of schemes being applied, including their modalities and communication aspects and whether these make a difference in impact (Box 1). The next sections present the timeline of announcements of APPs, followed by a detailed summary of their key features based on information in the database.

\footnotetext{
${ }^{8}$ See next subsection for further details.

${ }^{9}$ In the case of Norway, the CB was not involved in the conduct of the APP even though the measures were branded as CB asset purchases/sales (and thus included in the database). Rather, the government commissioned a dedicated fund to purchase private securities, e.g. equities.

10 The Bank of Thailand established the Corporate Bond Stabilization Fund to stabilize the corporate bond market.
} 


\section{Box 1. A Tale of Two Central Banks: India and South Africa}

The cases of India and South Africa help to highlight the diverse approaches taken by EMDE central banks in announcing and implementing UMP. Figure 3 presents the yields of sovereign bonds across different maturities. The vertical bars represent the dates at which the CBs announced the APP or provided new information. In both cases, purchases took place in secondary markets, were quantity-based, and there were no joint announcements with other national authorities. In the case of India, the second press release coincided with the implementation of a previously announced purchase (second darker green vertical bar).
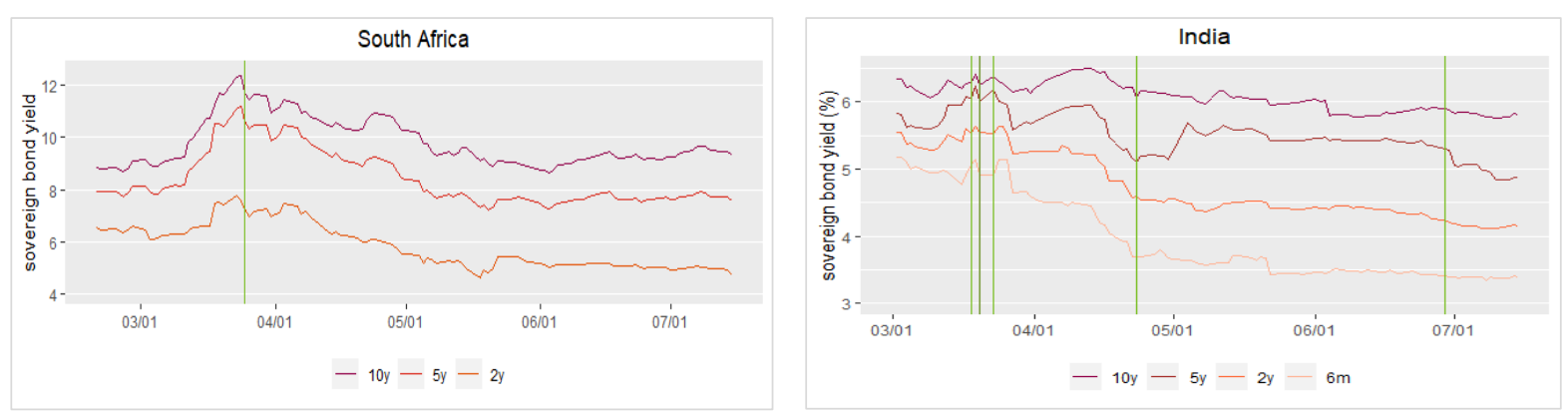

Both countries faced high sovereign bond yields in mid-March. In India, they had reached a historic high, whereas in South Africa, a 3 percent upward shift of the yield curve coincided with the onset of the pandemic. In response and with the objective of shoring up market confidence and tackling market dysfunctionality, both CBs announced APPs of government securities. However, their approaches were rather different.

The South African Reserve Bank (SARB) issued only one press release on March 25th. The press release gave no details on implementation (size, frequency, preannouncement, target maturities) of the program, but stated clearly that the new measure did not signal changes in the future monetary policy stance. The next day, the SARB published a Q\&A to answer markets queries and detailing heavily the APP objectives. The SARB also detailed how this program related to other recently introduced policies and specified that the program was neither direct financing nor debt monetization nor quantitative easing, and again did not represent a shift in the CB's mandate. Bond yields across all maturities were lower after the announcement.

The Reserve Bank of India (RBI) published numerous daily press releases related to the UMP, including diverse policy announcements, but (unlike the SARB) no detail on how it fit in with other policies. Instead, the press release remained factual and focused on the practicalities of the program. Implementation was on a discretionary basis, preannounced two days ahead. On March $18^{\text {th }}$, the RBI announced a first open market operation involving government dated securities. The quantity-based program implemented two days later received a "positive response". The RBI announced two 1.5-bigger tranche purchases on March $24^{\text {th }}$ and $30^{\text {th }}$, covering longer maturities. On March $23^{\text {rd }}$, the second purchase (announced on March $30^{\text {th }}$ ) was later advanced by four days (to March $26^{\text {th }}$ ). On April $23^{\text {rd }}$, the RBI announced a new type of "twist program" that replaced the existing program. The "twist program" included the simultaneous purchase of long-term securities and sale of short-term maturities, to be implemented two days later. On June $29^{\text {th }}$, the RBI announced another "twist"-like intervention to be made two days later in a similar amount, targeting slightly longer maturities. Overall, the APP announcements had only a slight effect on the bond yields at medium- and long-term maturities. Regarding the maturity of the assets, the RBI changed its target repeatedly over this period, initially purchasing 2 to 5 years bonds, then 2 to 9 years; and when the twist operation was introduced, sold securities with 2 months to 1 year maturity and purchased those with 6 to 10 years maturity, and subsequently sold securities with 3 to 10 months maturity and purchased those with 7 to 13 years maturity.

These two examples highlight both the diversity of country approaches to UMP and the importance of policy communication and other operational aspects. Some aspects that appear relevant from these two cases were frequency of announcements, whether the UMP was part of a policy package or not, and how much detailed information was included on the program (size, maturity of the securities purchased, pre-announced frequency and dates of implementation, counterparties), type and length of commentary on the rationale of the policy and its implications for the $\mathrm{CB}$ and the $\mathrm{CB}$ monetary policy stance, as well as differences in innovativeness (swap) and implementation (expansion of existing program or new program). 


\section{A. Timeline of APP Announcements}

This section highlights the timeline of the asset purchase program announcements recorded in the database.

APPs among EMDEs were announced mostly around the second half of March. Most of the APPs involved purchases of sovereign bonds (Figure 4).

Indonesia was the first, on March 2nd, 2020, to announce the start of sovereign bond purchases in order to "maintain monetary and financial market stability, including mitigating the risk of COVID-19." "The program was announced as part

Figure 4. APP Announcements by EMDEs by Type of Securities Purchased

Number of EMDEs announcing APP

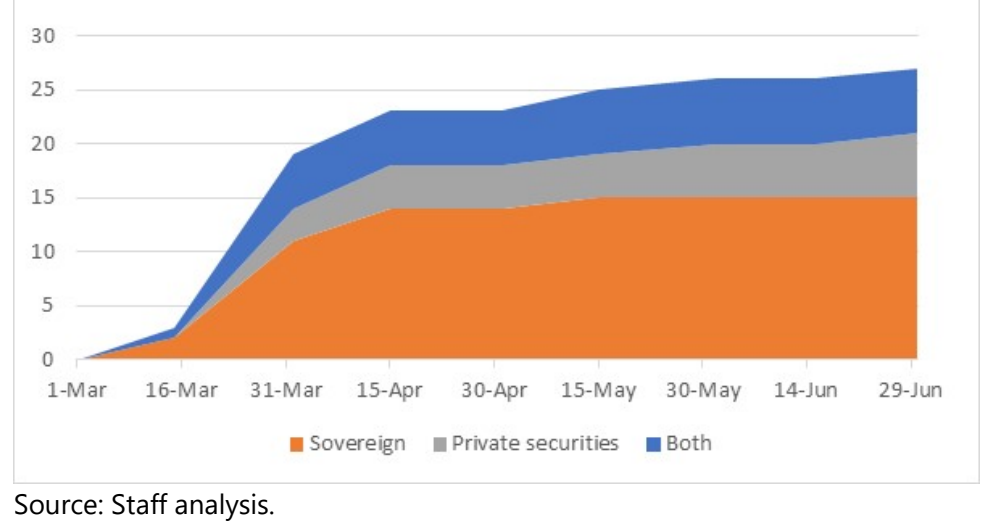
of a broader policy package including a reduction in reserve requirements, FX intervention, and repo operations. Mexico followed on March 12th, Croatia on March 13th, and then many other EMDEs in the second half of March. AEs also made similar announcements around the same time. While the U.S. Federal Reserve was establishing the Secondary Market Credit Facility (SMCCF, March 18th), involving the purchase of private securities, small advanced economies including Israel, Norway, Sweden, New Zealand were doing the same thing.

The last announcement in our sample was made at the end of June by the Brazilian central bank. It required a change in the CB mandate in order to conduct such interventions and clarified that this was "yet another available instrument, with no obligation to use." Other CBs required a change in the mandate as well in order to be able to conduct APPs.

EMDEs that announced APPs so far are very diverse in terms of their policy frameworks (Figure 5). The figure classifies countries according to three framework dimensions, monetary framework (inflation targeting (IT) vs non-IT), exchange rate framework (floating vs non-floating), and central bank transparency, and shows the share of EMDE countries announcing APPs in each country group. So, for instance, there is only one IT country among all EMDEs, with high level of central bank transparency and with a non-floating exchange rate, Indonesia, which announced an APP, so the share of EMDEs in that country group announcing APP is 100 percent. Most of the countries conducting APPs (58 percent) are classified as having inflation targeting (IT) frameworks and floating exchange rate regimes. By contrast, only 8 percent of the countries that announced an APP did not have an IT

\footnotetext{
${ }^{11}$ Central Bank Press Release, March 2nd, 2020.
} 
framework and floating exchange rate regime (Angola, Bolivia, Capo Verde, China, Croatia, Egypt, Ethiopia, and Papua New Guinea). Indonesia and Costa Rica pursue inflation targeting monetary policies but have respectively a stabilized exchange rate arrangement and a crawl-like arrangement. Mauritius has a form of "hybrid inflation targeting."

\section{Figure 5. APP Announcements by EMDEs and Policy Frameworks}

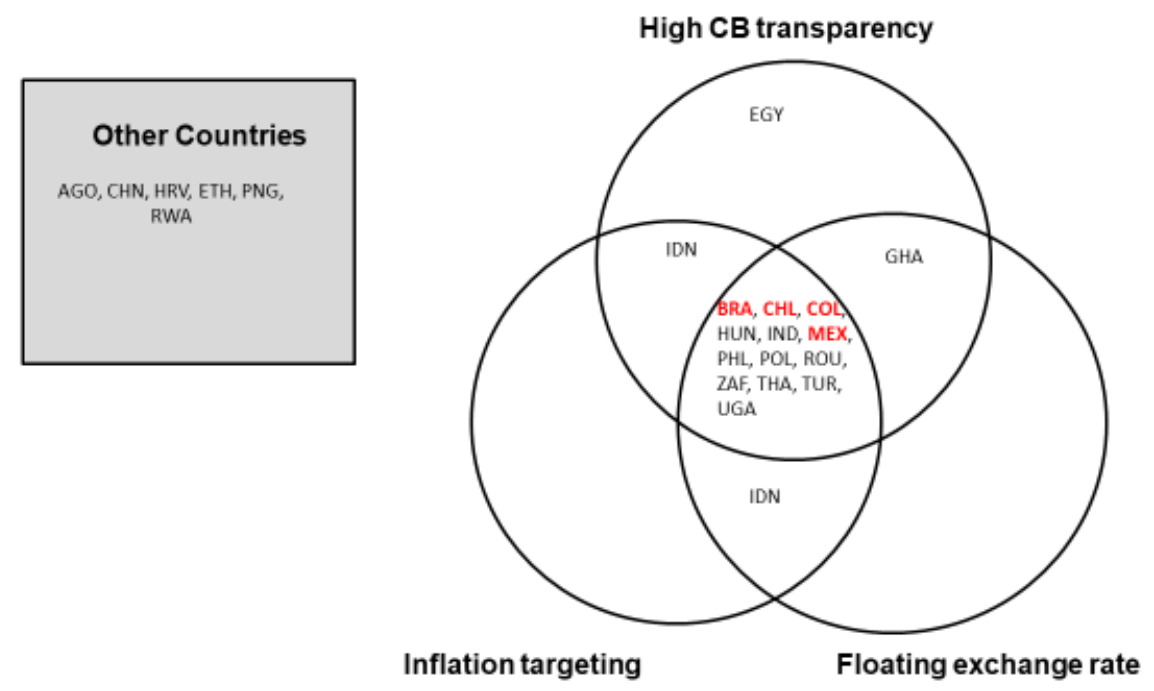

Note: The Central Bank Transparency Index is obtained from the Dincer/Eichengreen/Geraats revised Central Bank Transparency Data Set for 1998-2015. High central bank transparency is defined as those countries with above EMDE-average transparency index. Information on the IT and ER frameworks is obtained from the 2017 IMF Annual Report on Exchange Arrangements and Exchange Restrictions Database (AREAER). The EMDE average is computed over the sample of all EMDEs for which data is available.

The transparency of the central bank is correlated with the choice of starting an APP, as 41 percent of EMDEs with above average transparency of the central bank started APPs. ${ }^{12}$ The fraction is even higher among those who have above average transparency of the central bank and high non-residential investment share (50 percent). Countries with low CB transparency were less likely to announce an APP: only Jamaica among the countries with high nonresidential investment share and low CB transparency announced an APP; and 17 percent of those with low non-residential investment share and low CB transparency announced an APP.

\section{B. Implementation}

Information on implementation of the APPs is shown in Table 1, which lists the APPs for which transaction data (realized asset purchases) are publicly available (nearly all programs in AEs and less than a third of programs in EMDEs in our sample), the level of aggregation, and the number of observations.

\footnotetext{
12 The sample of EMDEs is restricted to those countries for which we have data availability.
} 


\begin{tabular}{|c|c|c|c|c|c|c|}
\hline \multicolumn{7}{|c|}{ Table 1. Availability of Transaction Data } \\
\hline \multicolumn{3}{|c|}{ EMDEs } & \multicolumn{4}{|c|}{ AEs } \\
\hline Programs without data on tran: & & & Progr & without data & 2 & \\
\hline Programs with transaction data & Aggregation & \# obs & Progr & with transaction data & Aggregation & \# obs \\
\hline $\mathrm{CHL} \quad$ private securities & Monthly & 1 & AUS & public securities & Daily & 215 \\
\hline private and private & Daily, month & 37 & CAN & private and private & Daily & 895 \\
\hline public securities & Monthly & 1 & ISL & public securities & Monthly & 3 \\
\hline public securities & Daily & 5 & ISR & private and private & Monthly & 8 \\
\hline private and private & Weekly & 16 & KOR & private securities & Daily & 2 \\
\hline public securities & Daily & 28 & NZL & public securities & Daily & 258 \\
\hline public securities & Weekly & 4 & SWE & private and private & Daily & 218 \\
\hline public securities & Daily & 65 & & & & \\
\hline public securities & Monthly & 3 & & & & \\
\hline public securities & Daily & 12 & & & & \\
\hline public securities & Daily & 9 & & & & \\
\hline
\end{tabular}

Figure 6 shows the size of the programs, in US\$ billion and percent of GDP. Some are sizeable relative to GDP (Bolivia, Iceland, and Mauritius) or in US\$ terms (Australia, Colombia, Israel, and Poland) or both (New Zealand).

Among countries for which the database includes both the announced size and the realized purchases as of August 2020, the latter are often smaller than announced, suggesting CBs still have room for more asset purchases in the near future (Figure 6). ${ }^{13}{ }^{14}{ }^{15}$ For example, the Chilean central bank made purchases in March 2020 amounting to US\$ 2.5 billion and it has not recorded any transaction ever since, despite initially announcing a US\$ 4 billion program, and then doubling it to US\$ 8 billion in April. Some other CBs are still conducting APPs and publishing transactions data as of August (e.g., India, Croatia, and Hungary).

\footnotetext{
${ }^{13}$ Whenever the amounts were expressed in local currency units, we used the 2020 end-of-period exchange rate from the last published WEO to convert the amounts. The amounts in percentage of GDP are computed using the 2019 GDP estimate from the last published WEO. The amount in USD for China is truncated for expositional purposes.

${ }^{14}$ For Thailand, we present the announced size of both its private and public purchase programs, but we only have data on purchases of sovereign bonds. For Korea, we only report the size of the sovereign debt purchase program.

${ }^{15}$ For Turkey, data on implementation refers only to purchases of government bonds from the Unemployment Insurance Fund.
} 


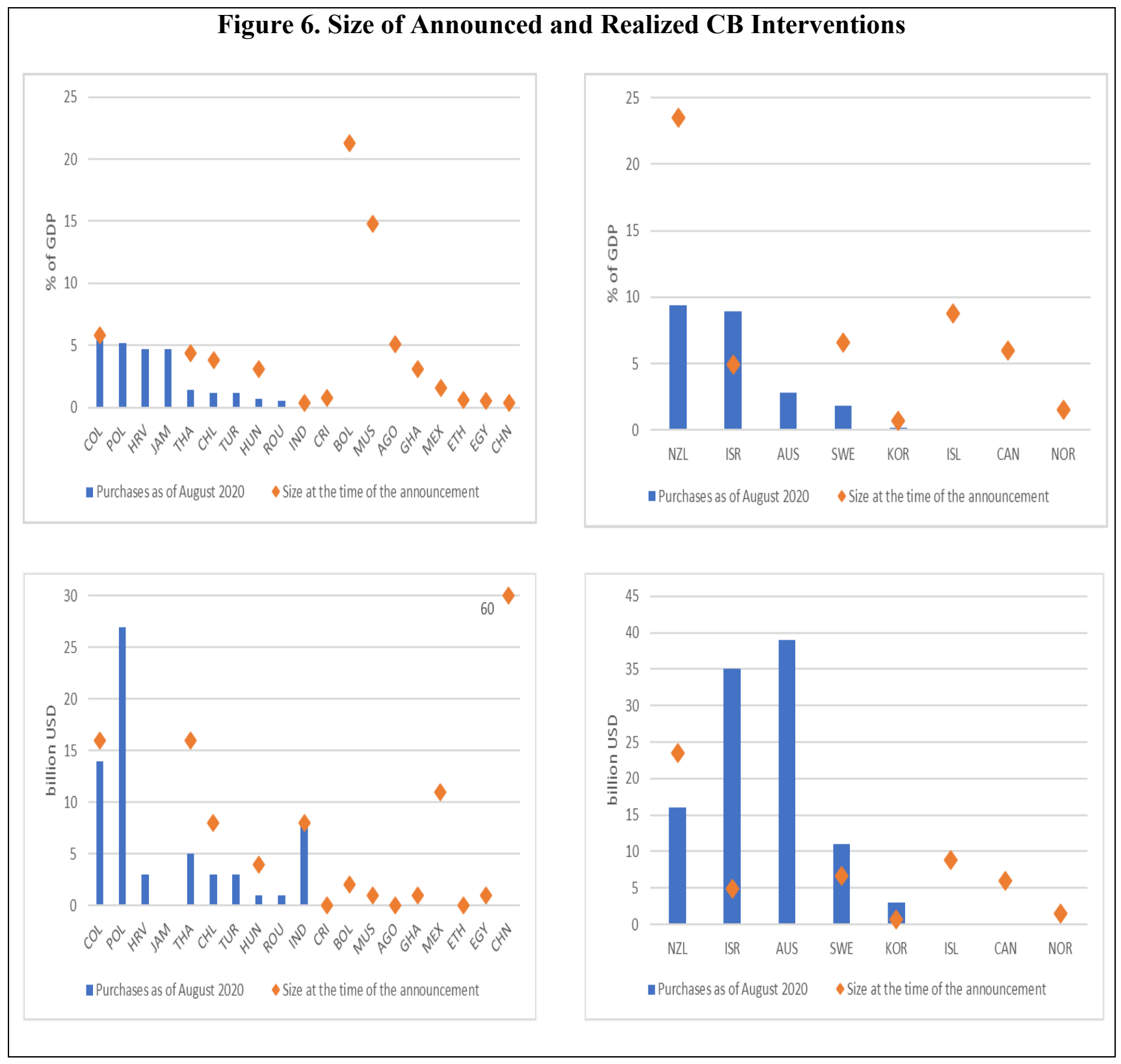

Central banks in EMDEs announced and implemented APPs quickly (Figure 7). ${ }^{16}$ Croatia implemented its APP on the same day as the announcement, while Poland started the implementation three days after the program was officially mentioned by the NBP management. The speed of implementation is comparable, if not faster, to what we observe among AEs, where implementation ranged from one day since the first announcement (Australia, Korea), to nine days (Sweden).

\footnotetext{
16 The sample in the Figure is restricted to those countries for which we have an exact date of implementation.
} 
Figure 7. Implementation of APPs Over Time 1/

\begin{tabular}{llll} 
& March & April \\
\hline 15 & 20 & 31
\end{tabular}

$\begin{array}{ll} & \text { COL } \\ \text { EMDES } & \text { HRV } \\ & \text { IND } \\ & \text { POL } \\ & \text { TUR }\end{array}$

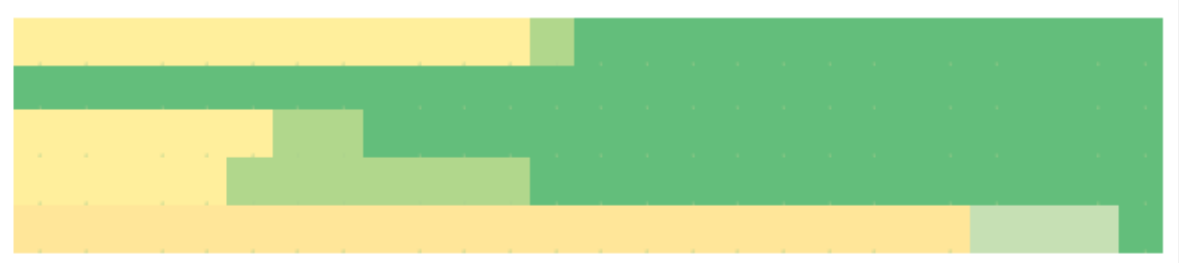

\begin{tabular}{lll}
\hline \multirow{4}{*}{ AES } & AUS \\
CAN \\
KOR \\
\\
\\
\\
\\
& NZL \\
SWE
\end{tabular}

1/ Light green are days in which the APP has already been announced but implementation has not started yet. Dark green are days in which APP implementation has started. Korea includes only the program involving the purchase of sovereign bonds.

Source: Staff analysis.

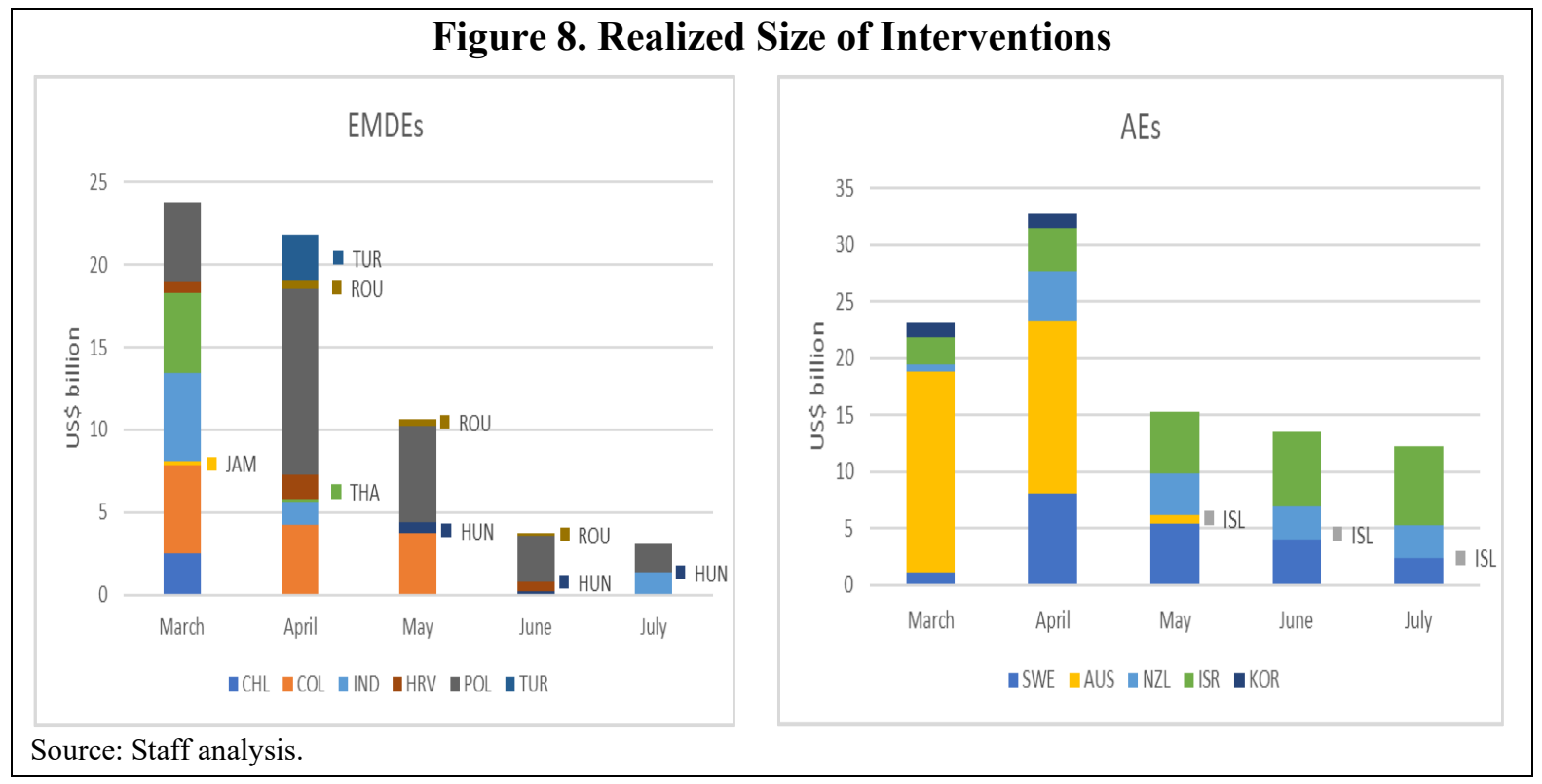

CInternational Monetary Fund. Not for Redistribution 


\section{Key Features of the APPs}

\section{Stated Objectives}

Concerns related to market dysfunctionalities and the need to restore confidence are among the top objectives mentioned by CBs in EMDEs when announcing these new programs (Figure 9). ${ }^{17}$ In line with their initial conditions, only in 9 percent of the cases the objective of the APP in EMDEs is to provide monetary stimulus (Bolivia, Angola, Costa Rica, Mauritius).This is in line with stated objectives for APPs in AEs. ${ }^{18}$

\section{Figure 9. Stated Objective of APP Announcements in EMDEs}

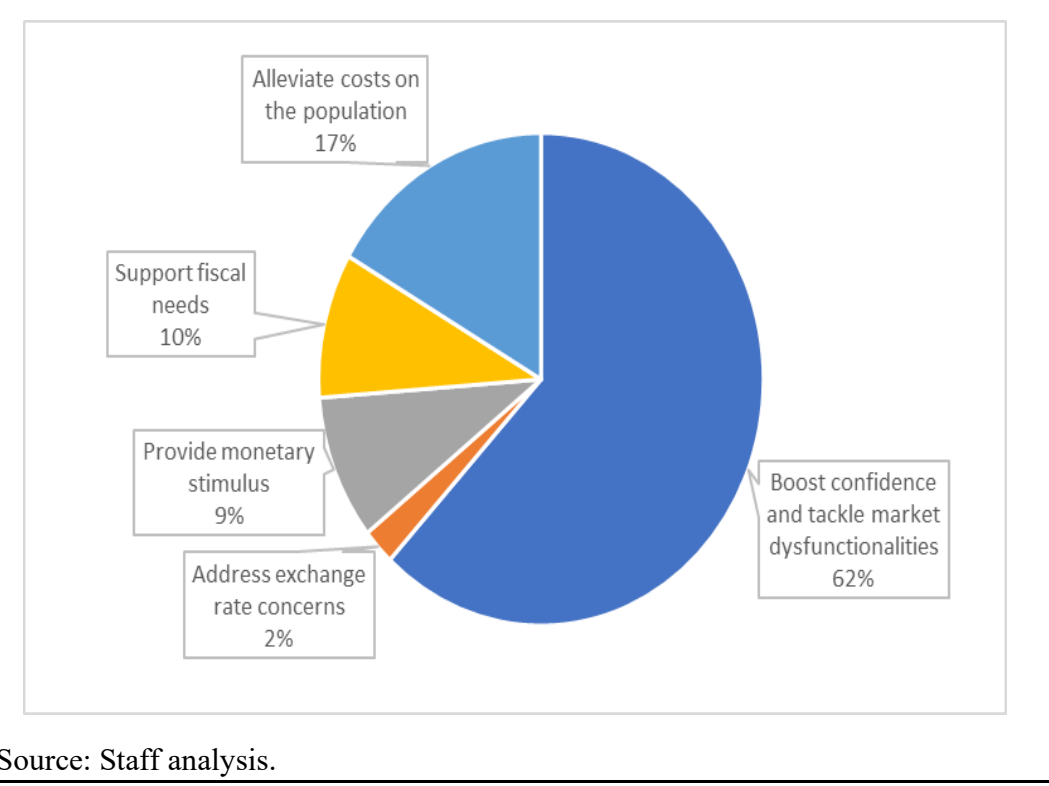

17 percent of the programs mention explicitly the need to alleviate the costs of COVID-19 outbreak on the population as their main objective (Angola, Bolivia, Cabo Verde, Indonesia, Mauritius, Poland, Rwanda). Supporting the fiscal needs is stated as an objective in 10 percent of the cases (Ghana, Indonesia, Mauritius). Poland mentions the need to "mitigate the negative impact of Coronavirus spread," when referring to the whole policy package. ${ }^{19}$ Angola mentions the need to mitigate the "possible impacts of the COVID-19 pandemic on the national economy, with particular attention to the external accounts, and its implications in the conduct of the monetary and exchange rate policies" and "to provide direct support to the productive sector and to ease the pressure on the cash flow of these companies, major

\footnotetext{
${ }^{17}$ Countries are counted more than once if they announced more than one program and/or stated more than one objective.

${ }^{18}$ Among AEs, 80 percent of the programs had as stated objective boosting confidence and tackling market dysfunctionalities (Australia, Iceland, Israel, Korea, New Zealand, Sweden) and 20 percent to provide monetary stimulus (Israel, New Zealand).

19 " $[\ldots]$ all the above-mentioned measures will mitigate the negative economic impact of coronavirus spread, while further ahead they will contribute to recovery in domestic economic activity and will be conducive to inflation running at the level of the NBP inflation target in the medium term." Narodowy Bank Polski, Information from the meeting of the Monetary Policy Council held on 17.03.2020. https://www.nbp.pl/en/aktualnosci/2020/mpc_2020_03_17.pdf
} 
employers, allowing them to continue operating and, consequently, maintain jobs." ${ }^{20}$ Other countries, instead, mention the budget financing as a goal of the program: Indonesia declared that the APP was "a source of funding for the government in the context of national economic recovery", and they saw it "as the last resort in the event that the market capacity is unable to absorb and/or causes a yield increase that is too high." ${ }^{21}$ Mauritius stated that the APP had the goal of "assisting the government in its fiscal measures to stabilize the economy. ${ }^{22 "}$ The central bank in Ghana declared in their press release dated May 15, 2020, that "under the circumstances [...], the Bank of Ghana has triggered the emergency financing provisions, which permits the Bank to increase the limit of BOG's purchases of government securities in the event of any emergency to help finance the residual financing gap." ${ }^{23}$ Indonesia is the only country declaring the exchange rate to be one of the objectives of the APP, while also mentioning market dysfunctionalities and support for fiscal needs among the objectives. Specifically, the Indonesian central bank introduced the APP in order "to minimize the risk of increasing volatility in the Rupiah exchange rate" and as part of a broader intervention to ensure "that the Rupiah exchange rate moves according to its fundamentals and follows market mechanisms."

\footnotetext{
${ }^{20}$ Banco National de Angola, Press Release, April 15, 2020, and May 7, 2020 https://www.bna.ao/Conteudos/Artigos/detalhe artigo.aspx?idc $=175 \& \mathrm{idl}=2 \& \mathrm{idi}=16800$ https:/www.bna.ao/Conteudos/Artigos/detalhe artigo.aspx?idc=175\&idl=2\&idi=16831

${ }^{21}$ Central bank press release, April 21, 2020. The phrase cited in the text has been translated using Google translate. https://www.bi.go.id/id/ruang-media/info-terbaru/Pages/BI-Terbitkan-Ketentuan-Pelaksanaan-LelangSUN-dan-atau-SBSN-Jangka-Panjang-di-Pasar-Perdana.aspx

22 Bank of Mauritius, Covid-19 Support Programme: Supporting Systemic Economic Operations and Financial Stability. https://www.bom.mu/media/covid19-actions/covid-19-support-programme-supporting-systemiceconomic-operators-and-financial-stability
}

${ }^{23}$ Bank of Ghana, Monetary Policy Committee Press Release, May 15, 2020. https://www.bog.gov.gh/wpcontent/uploads/2020/05/MPC-Press-Release-15th-May-2020-2.pdf 


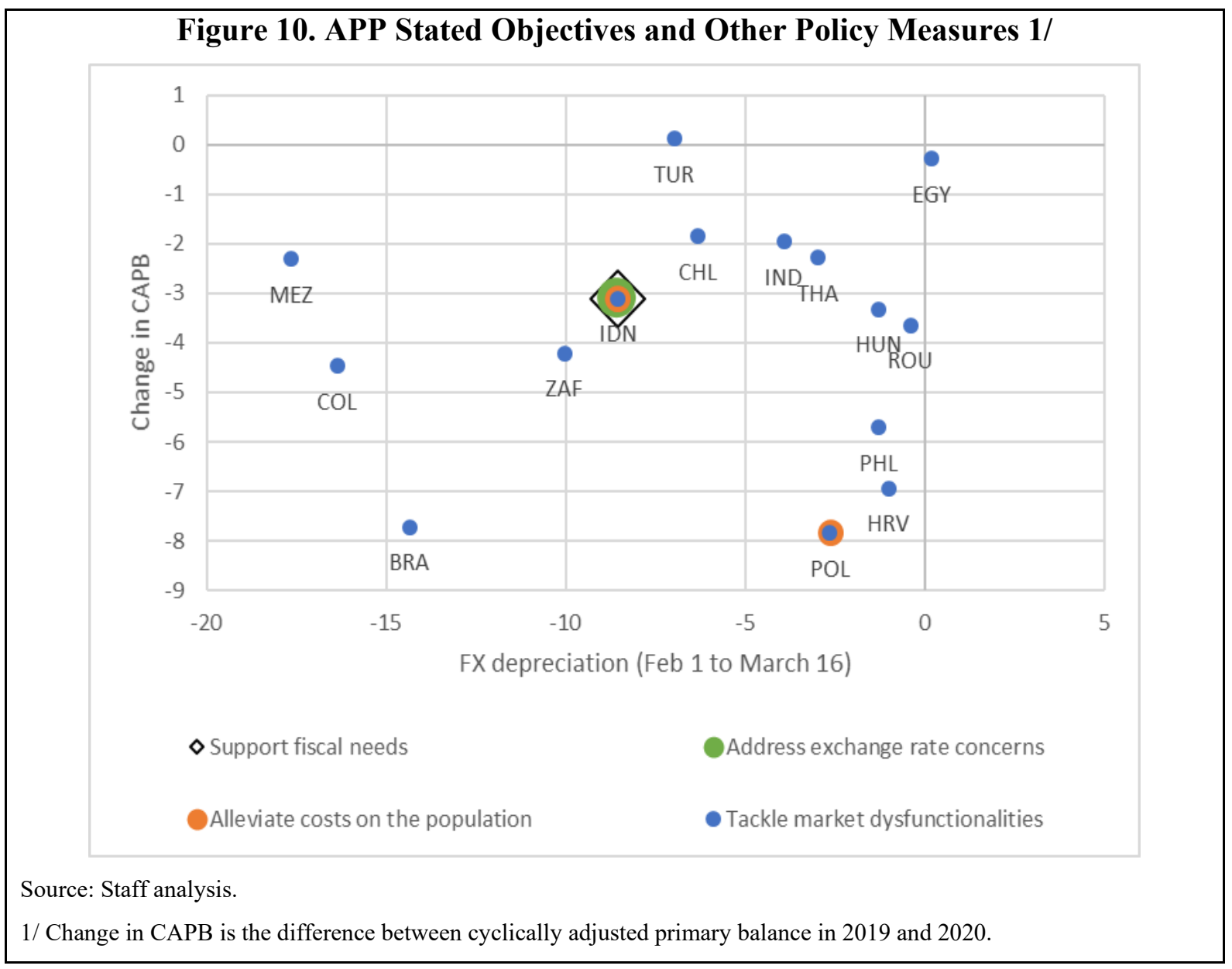

Except in two cases (Turkey and BEAC), APP announcements in EMDEs coincided with other policy measures by CBs (Table 2 and Figure 10). For AEs, by contrast, there were more cases of stand-alone APP announcements (Iceland, Korea, New Zealand, Norway). ${ }^{24}$ In particular, APP announcements coincided ${ }^{25}$ with policy rate cuts in the case of Egypt, Philippines $^{26}$, Chile, Poland, Hungary, Romania, Capo Verde, Indonesia, Mexico, Uganda, and Papua New Guinea. This table does not include the instances in which the central bank cut its interest rates in days in which there were no APP announcements.

\footnotetext{
${ }^{24}$ The information reported refers to announced policies. Policies implemented and not announced would not be captured in the dataset.

${ }^{25}$ We consider that policy rate cuts consider with APP announcements if they occurred simultaneously, the day before, or a few days before.

${ }^{26}$ The policy rate cut was on April $16^{\text {th }}$.
} 


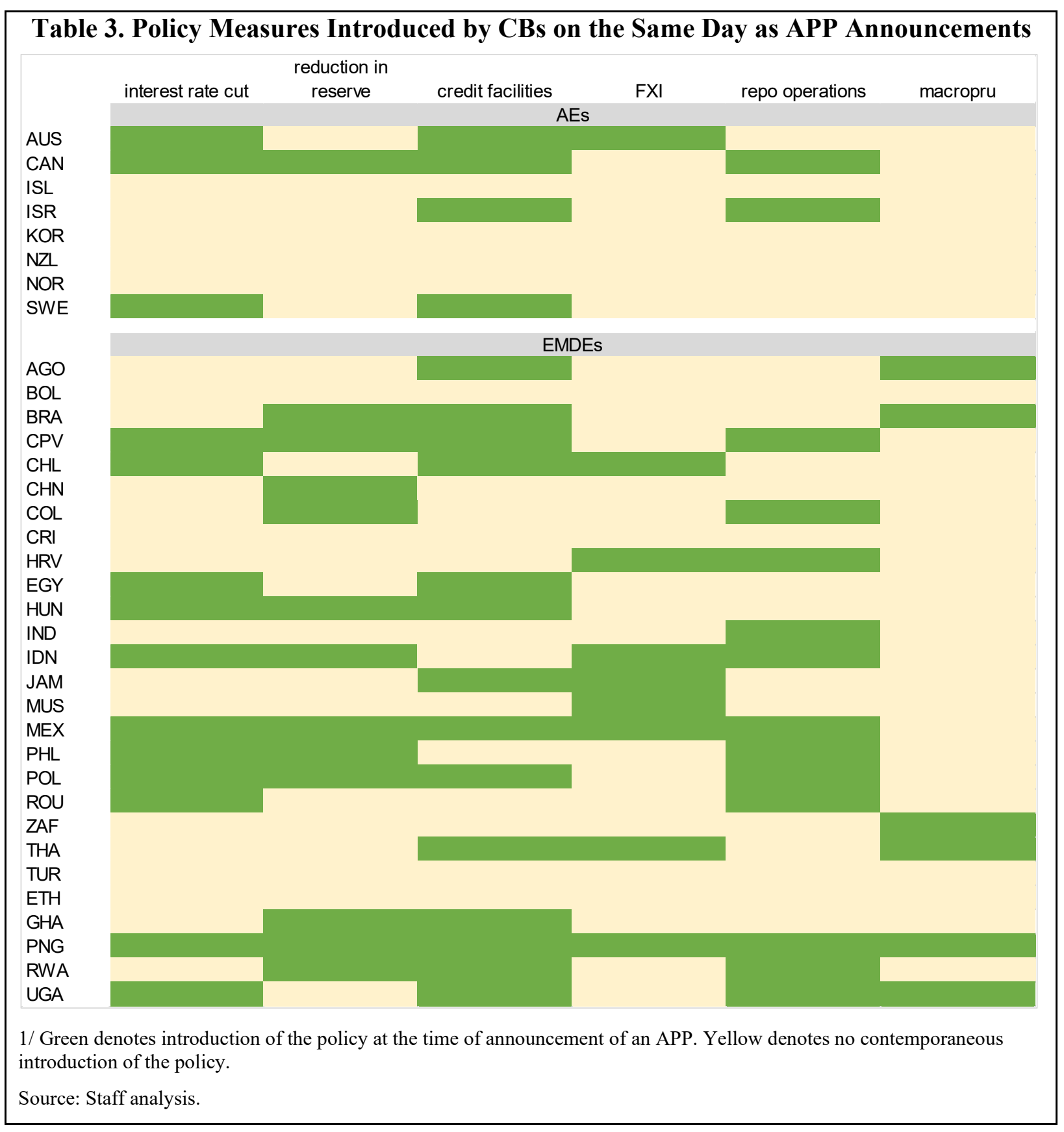

\section{Modalities}

While more than half (17) of the EMDE CBs announced interventions exclusively in the sovereign market, there are important exceptions: Brazil, Chile, China, Egypt, Ethiopia, and Thailand envisaged purchases of private securities; Colombia, Hungary, Mauritius, and Mexico announced programs involving both private and public securities. For instance, the Chilean central bank is not legally allowed to purchase sovereign bonds, and therefore only purchased bank bonds. Egypt purchased equities to "support asset prices amid sustained market volatility." Hungary announced contemporaneously the purchase of sovereign bonds 
and mortgage securities. A month after starting the intervention in the sovereign bond market, Mexico announced a new APP targeting private securities, "to promote an orderly behavior of Mexico's debt market." 27

The majority of countries among both EMDEs and AEs are conducting APPs exclusively in the secondary markets (Figure 11). Among the exceptions of APPs conducted in the primary markets are Bolivia, Indonesia, Ghana, Cabo Verde, ${ }^{28}$ Thailand, and Norway. Bolivia announced simultaneously the purchase of US\$ 1 billion in sovereign bonds on the primary market, and of US\$ 500 million on the secondary market, to "preserve the lives of Bolivian people and avoid the crisis state experienced by more developed countries, who delayed measures." After a Presidential decree initially announced an APP of sovereign bonds on the primary markets, the CB of Indonesia announced the beginning of purchases on the primary market, as a "source of funding for the government in the context of national economic recovery, including maintaining the sustainability" of the government. The Norwegian government reinstated the Government Bond Fund, initially established in 2008, to purchase in the primary and the secondary market bonds issued by companies headquartered in Norway with credit rating above CCC-. South Africa clarified in their announcements that their APPs in secondary markets did not constitute direct financing. ${ }^{29}$

\footnotetext{
27 The Polish central bank purchased government-guaranteed debt securities besides sovereign bonds. In our database, it is classified as APP in the sovereign market.

${ }^{28}$ In line with APPs' objective to provide support to fiscal needs related to the COVID-19 outbreak (Figure 9).

${ }^{29}$ The South African Reserve Bank stated "No, we are not monetising the government debt. The SARB is not giving money directly to government and is not buying bonds from government". Czech Republic never announced an APP. However, the CB mandate was changed and the CB press releases stated: "The amendment to the Act on the CNB concerning CNB open market operations which was approved by the government today does not affect the prohibition of monetary financing."
} 


\section{Figure 11. Asset Purchase Programs by Primary vs. Secondary Market Purchases}

Emerging Market and Developing

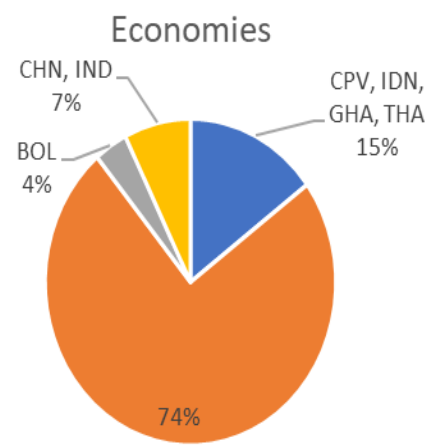

- Primary $\square$ Secondary $\|$ Both $\| \mathrm{NA}$

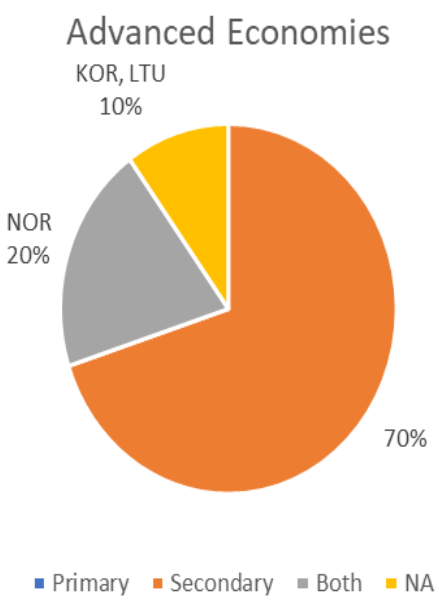

1/ Percentage of programs.

Source: Staff Analysis.

Quantity-based programs prevail among both EMDEs and AEs (Figure 12). An exception is Chile, which announced a price-based APP targeting bank bonds (Swap de Tasas Promedio Cámara or SPC plus 2.5 percent for AAA-rated bonds, SPC plus 2.6 percent for AA-rated bonds, and SPC plus 2.8 percent for A-rated bonds). Australia pursued a similar approach and announced a target for the yield on government bonds of around 0.25 per cent.

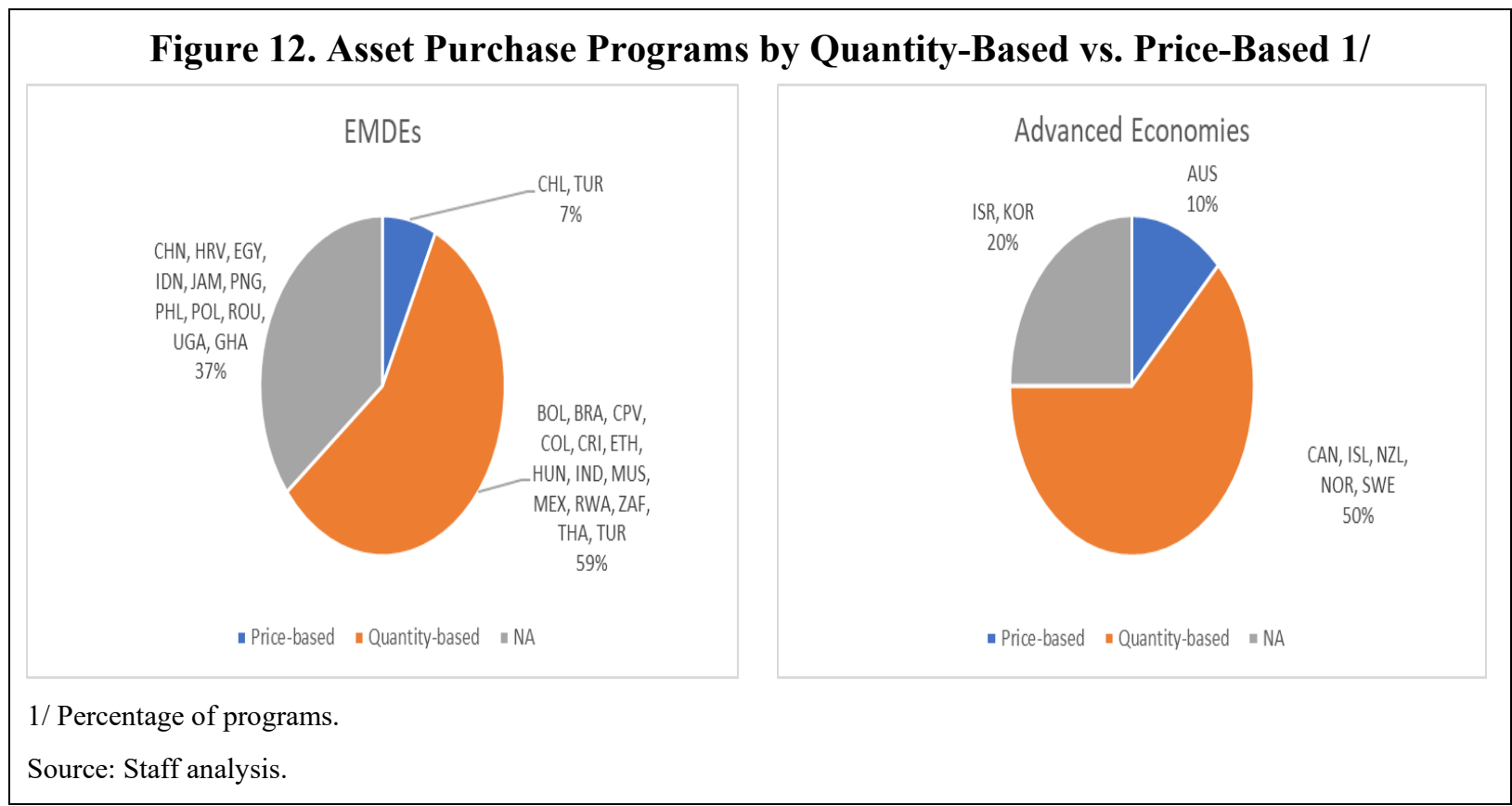


While most CBs do not mention specific maturities, EMDEs are overall more likely than AEs to specify the maturities targeted (Figure 13). ${ }^{30} 19$ percent of the programs among AEs (Canada, Korea) targeted short-term maturities, compared to 3 percent among EMDEs: among EMDEs, Colombia is the only CB targeting short-term securities (up to three years, private securities). No AE targeted long-term securities, while 11 percent of the CBs among EMDEs did. Many countries in our sample operated APPs on the broad yield curve. For example, Hungary's APP encompassed all private securities and sovereign bonds of three year or higher duration. Finally, some countries which conducted APPs along the broad yield curve started swap programs, selling bonds of short maturity and purchasing those of long maturity (Colombia, India, Mexico).

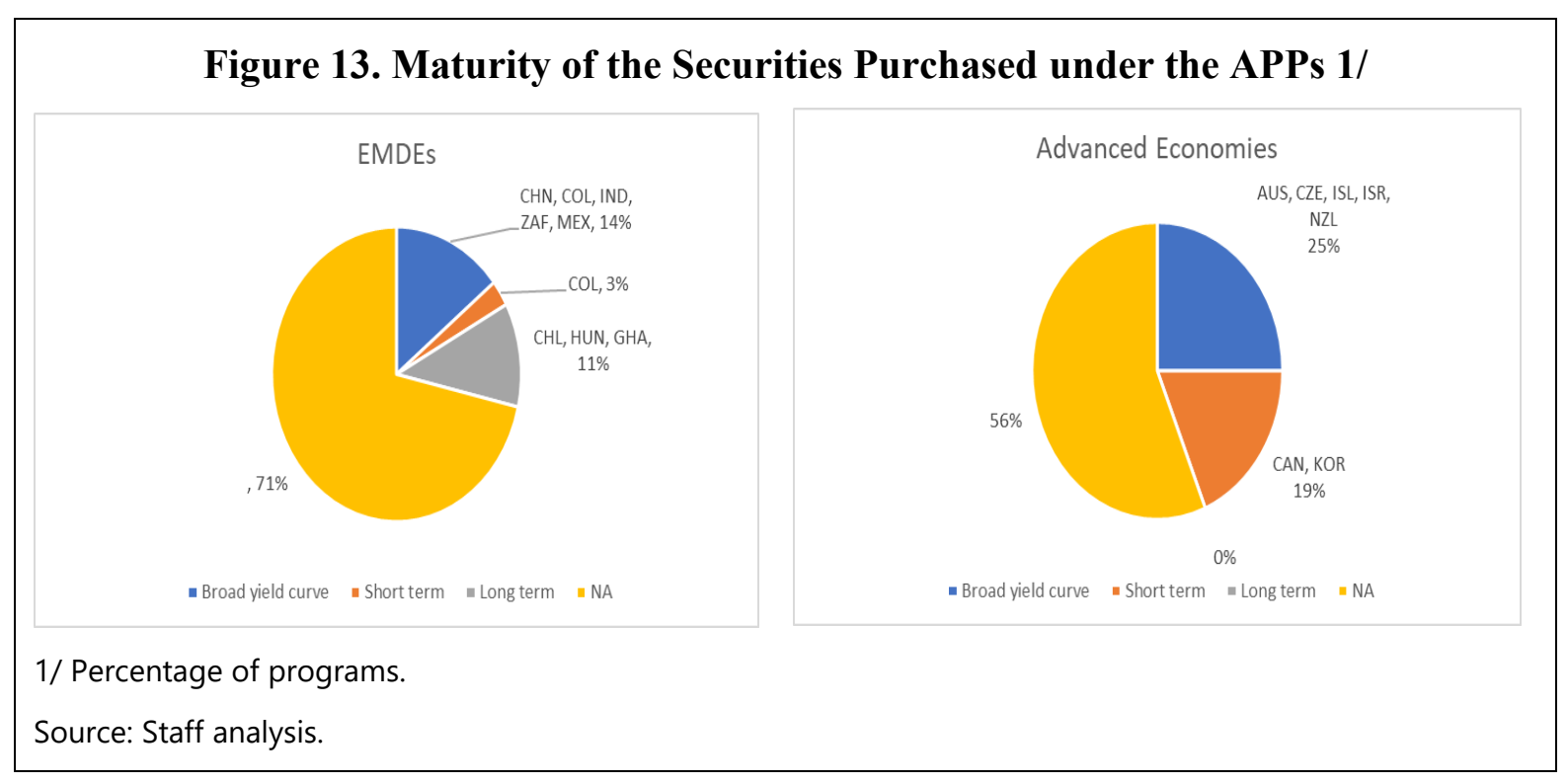

\section{Other operational aspects: coordination and communication}

While most central banks made announcements independently of other national authorities, some instances of coordination of the CB with the government occurred across all income groups. For example, in Egypt, the President announced the APP and no information was provided or announced directly by the central bank. Among EMDEs, joint announcements were made in Thailand, Mexico, China, and Indonesia. In the case of Indonesia, the introduction of the APP on March 31st was the result of a Presidential decree, and it was jointly announced with the Ministry of Finance. In Ethiopia, the announcement was made by the Prime Minister. Among AEs, the cases of Korea and Norway are worth mentioning. In Korea, the central bank set up an SPV with joint support from government-run financial institutions to purchase private securities. In Norway, the APP was conducted by the government rather than the central bank.

\footnotetext{
${ }^{30}$ Countries are listed more than once if announced programs with different maturity targets. The information reported is related to the most updated information provided by the central bank.
} 
The extent of information made available by CBs when introducing an APP varies across the sample and is higher for advanced economies than for EMDEs. For each announcement in our database we collected up to 27 variables on the description of the APP at the moment of the announcement, ranging from the objective, the size of the program, the implementation timeframe, etc. ${ }^{31}$ The number of variables collected is a rough indicator of the communication strategy implemented by the different central banks. ${ }^{32}$

Canada's central bank scores the highest on this metric of transparency and communication, providing

Figure 14. Information Available in APP Announcements 1/

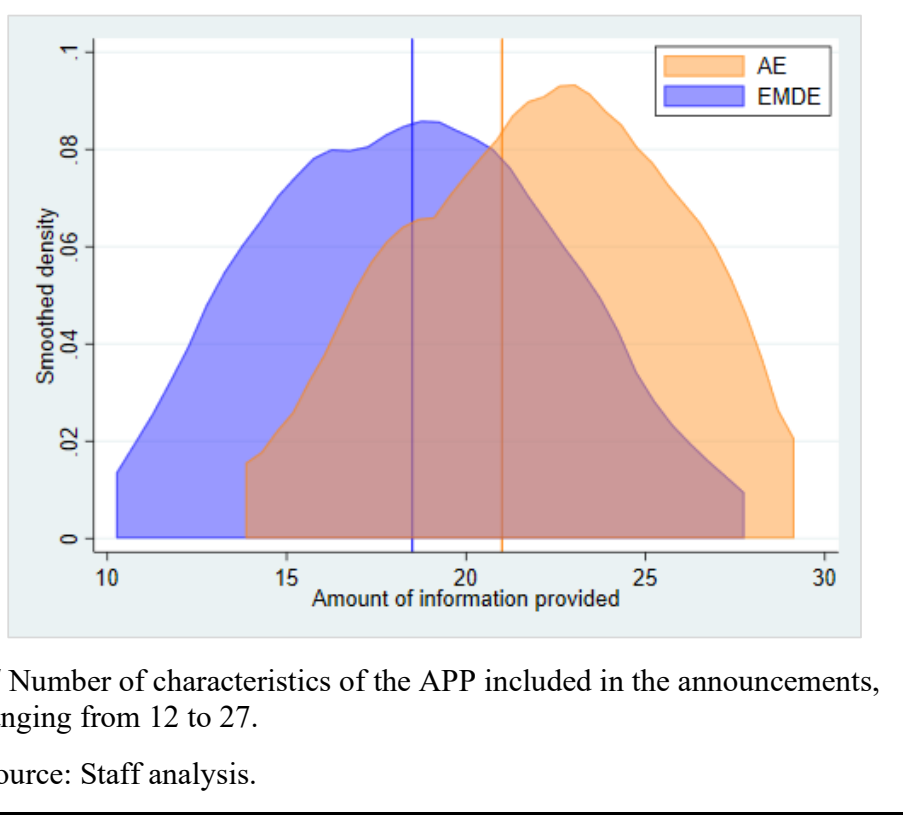
information on all 27 variables collected in our database. At the opposite extreme, Romania provided information on 12 variables. However, it should be noted that this list excludes those countries for which we were not able to collect a minimum amount of publicly available information on the programs. Overall, by comparing the distributions on the amount of information collected between central banks of AEs and EMDEs (Figure 14), the latter on average provide less comprehensive information. Exceptions include Colombia, India, and Mexico, ranking respectively first, second, and third among EMDEs in the extent of information provided. ${ }^{33}$

\footnotetext{
${ }^{31}$ For a description of the database and the variables included see Annex I.

${ }^{32}$ The metric is imperfect as quantity of information may not necessarily capture the quality/impact of the communication but nonetheless helps to illustrate the diverse $\mathrm{CB}$ communication strategies across countries.

${ }^{33}$ We also identify South Africa and Costa Rica as having a detailed communication strategy, with long and detailed $\mathrm{CB}$ announcements.
} 


\begin{tabular}{|c|c|c|c|c|c|c|c|c|c|c|c|c|c|c|}
\hline \multirow[b]{3}{*}{ Country } & \multicolumn{13}{|c|}{ Table 4. Summary of Asset Purchase Programs } & \multirow[b]{3}{*}{ Objective } \\
\hline & \multirow[b]{2}{*}{$\begin{array}{l}\text { First } \\
\text { announcement }\end{array}$} & \multirow[b]{2}{*}{$\begin{array}{l}\text { First } \\
\text { implementation }\end{array}$} & \multicolumn{3}{|c|}{ Announced size ${ }^{34}$} & \multicolumn{3}{|c|}{ Realized size 35} & \multirow[b]{2}{*}{ Assets } & \multirow[b]{2}{*}{$\begin{array}{l}\begin{array}{l}\text { Type of } \\
\text { purchase }\end{array} \\
\end{array}$} & \multirow[b]{2}{*}{$\begin{array}{l}\text { Primary } \\
\text { Market }\end{array}$} & \multirow{2}{*}{\multicolumn{2}{|c|}{$\begin{array}{l}\text { Quantity } \\
\text { /Price } \\
\text { based } \\
\end{array}$}} & \\
\hline & & & $\begin{array}{l}\text { USD } \\
\text { (bn) }\end{array}$ & $\begin{array}{l}\mathrm{LCU} \\
(\mathrm{bn}) \\
\end{array}$ & $\begin{array}{l}\% \\
\mathrm{GDP}^{36} \\
\end{array}$ & $\begin{array}{l}\text { USD } \\
\text { (bn) }\end{array}$ & $\begin{array}{l}\text { LCU } \\
\text { (bn) }\end{array}$ & $\begin{array}{l}\% \\
\mathrm{GDP}^{37} \\
\end{array}$ & & & & & & \\
\hline Adva & ad Econc & mies & & & & & & & & & & & & \\
\hline Australia & 19-Mar-20 & 20-Mar-20 & & & & 35 & 53 & 2.8 & $\begin{array}{l}\text { Sovereign } \\
\text { bonds, } \\
\text { local } \\
\text { governme } \\
\text { nt bonds }\end{array}$ & Outright & $\mathrm{N}$ & $\mathrm{P}$ & $\begin{array}{l}\text { all yield } \\
\text { curve }\end{array}$ & $\begin{array}{l}\text { Boost confidence } \\
\text { and tackle market } \\
\text { dysfunctionalities. }\end{array}$ \\
\hline Canada & 24-Mar-20 & 25-Mar-20 & 38 & 50 & 2.4 & & & & Sovereign & Outright & $\begin{array}{l}\text { Primary } \\
\text { and } \\
\text { Second. }\end{array}$ & Q & & $\begin{array}{l}\text { Boost confidence } \\
\text { and tackle market } \\
\text { dysfunctionalities. }\end{array}$ \\
\hline Canada & 13-Mar-20 & 23-Mar-20 & 57 & 75 & 3.6 & & & & Private & Outright & $\begin{array}{l}\text { Primary } \\
\text { and } \\
\text { Second. }\end{array}$ & $\mathrm{Q}$ & & $\begin{array}{l}\text { Boost confidence } \\
\text { and tackle market } \\
\text { dysfunctionalities. }\end{array}$ \\
\hline Iceland & 23-Mar-20 & May 2020 & 1 & 150 & 9.2 & 0 & 1 & 0.1 & $\begin{array}{l}\text { Sovereign } \\
\text { bonds }\end{array}$ & Outright & $\mathrm{N}$ & Q & & $\begin{array}{l}\text { Boost confidence } \\
\text { and tackle market } \\
\text { dysfunctionalities. }\end{array}$ \\
\hline Israel & 15-Mar-20 & March 2020 & 14 & 50 & 3.7 & 34 & 118 & 8.8 & $\begin{array}{l}\text { Sovereign } \\
\text { bonds }\end{array}$ & Outright & $\mathrm{N}$ & NA & $\begin{array}{l}\text { various } \\
\text { maturities }\end{array}$ & $\begin{array}{l}\text { Boost confidence } \\
\text { and tackle market } \\
\text { dysfunctionalities. }\end{array}$ \\
\hline Israel & $6-\mathrm{Jul}-20$ & March 2020 & 4 & 15 & 1.1 & 0 & 2 & 0.1 & $\begin{array}{l}\text { Corporate } \\
\text { bonds }\end{array}$ & Outright & $\mathrm{N}$ & NA & & $\begin{array}{l}\text { Boost confidence } \\
\text { and tackle market } \\
\text { dysfunctionalities. } \\
\text { Provide monetary } \\
\text { stimulus. }\end{array}$ \\
\hline Korea & 19-Mar-20 & 20-Mar-20 & 3 & 3000 & 0.2 & 3 & 3000 & 0.2 & $\begin{array}{l}\text { Sovereign } \\
\text { bonds }\end{array}$ & Outright & $\mathrm{N}$ & NA & $\begin{array}{l}3-, 5-\text {, and } \\
10 \text {-year }\end{array}$ & $\begin{array}{l}\text { Boost confidence } \\
\text { and tackle market } \\
\text { dysfunctionalities. }\end{array}$ \\
\hline Korea & 24-Apr-20 & & 8 & 10000 & 0.5 & & & & $\begin{array}{l}\text { Private } \\
\text { securities }\end{array}$ & Outright & $\mathrm{N}$ & NA & $\begin{array}{l}\text { less than } 3 \\
\text { years }\end{array}$ & $\begin{array}{l}\text { Boost confidence } \\
\text { and tackle market } \\
\text { dysfunctionalities. }\end{array}$ \\
\hline $\begin{array}{l}\text { New } \\
\text { Zealand }\end{array}$ & 20-Mar-20 & 25-Mar-20 & 38 & 60 & 22.4 & 15 & 24 & 9.4 & $\begin{array}{l}\text { Sovereign } \\
\text { bonds, } \\
\text { local } \\
\text { governme } \\
\text { nt bonds }\end{array}$ & Outright & $\mathrm{N}$ & $Q$ & $\begin{array}{l}1 \text { to } 20 \text {-year } \\
\text { for sov., } 1 \\
\text { to } 13 \text { y for } \\
\text { local govt }\end{array}$ & $\begin{array}{l}\text { Boost confidence } \\
\text { and tackle market } \\
\text { dysfunctionalities. } \\
\text { Provide monetary } \\
\text { stimulus. }\end{array}$ \\
\hline
\end{tabular}

\footnotetext{
${ }^{34}$ In the case of Iceland, represents an upper bound.

${ }^{35}$ Realized size refers to the amount of realized transactions until August 2020, if data is available.

${ }^{36}$ Percent of 2019 GDP.
} 


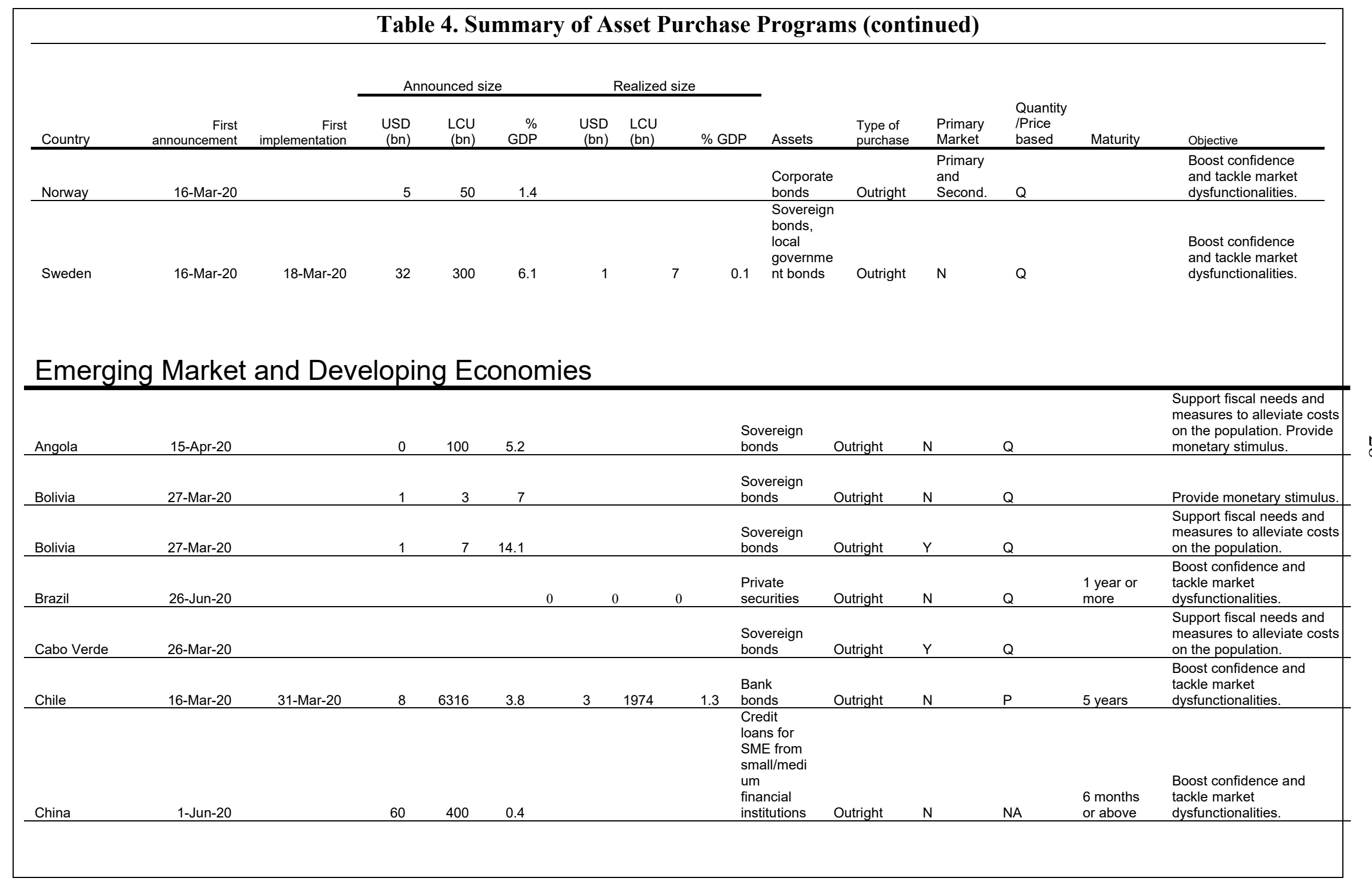




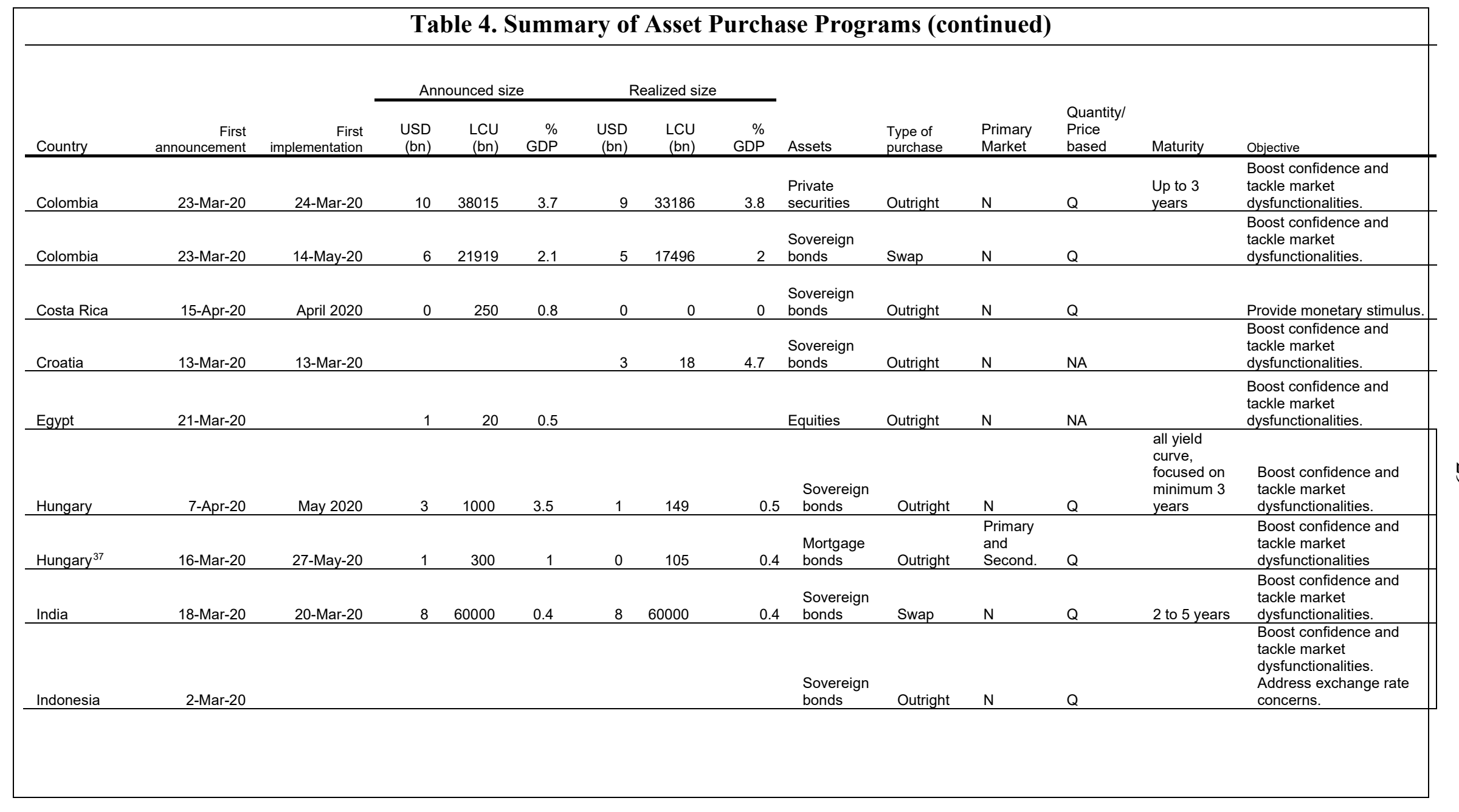

\footnotetext{
${ }^{37}$ On March 24th, the Magyar Nemzeti Bank stated they were assessing "the possibility of relaunching the MNB's mortgage bond purchase program to increase bank liquidity, while the Financial Stability Council has temporarily loosened its regulation on mortgage bond funding." Press Release on the Monetary Council Meeting of 24 March 2020.
} 


\begin{tabular}{|c|c|c|c|c|c|c|c|c|c|c|c|c|c|c|}
\hline \multirow[b]{2}{*}{ Country } & \multirow[b]{2}{*}{$\begin{array}{r}\text { First } \\
\text { announcement }\end{array}$} & \multirow[b]{2}{*}{$\begin{array}{r}\text { First } \\
\text { implementation }\end{array}$} & \multicolumn{3}{|c|}{ Announced size } & \multicolumn{2}{|c|}{ Realized size } & \multirow[b]{2}{*}{$\%$ GDP } & \multirow[b]{2}{*}{ Assets } & \multirow[b]{2}{*}{$\begin{array}{l}\text { Type of } \\
\text { purchase }\end{array}$} & \multirow[b]{2}{*}{$\begin{array}{l}\text { Primary } \\
\text { Market }\end{array}$} & \multirow[b]{2}{*}{$\begin{array}{l}\text { Quantity/ } \\
\text { Price } \\
\text { based }\end{array}$} & \multirow[b]{2}{*}{ Maturity } & \multirow[b]{2}{*}{ Objective } \\
\hline & & & $\begin{array}{l}\text { USD } \\
\text { (bn) }\end{array}$ & $\begin{array}{l}\text { LCU } \\
\text { (bn) }\end{array}$ & $\begin{array}{l}\% \\
\text { GDP }\end{array}$ & $\begin{array}{l}\text { USD } \\
\text { (bn) }\end{array}$ & $\begin{array}{l}\text { LCU } \\
\text { (bn) }\end{array}$ & & & & & & & \\
\hline Indonesia & 31-Mar-20 & & & & & & & & $\begin{array}{l}\text { Sovereign } \\
\text { bonds }\end{array}$ & Outright & $Y$ & NA & & $\begin{array}{l}\text { Support fiscal needs and } \\
\text { measures to alleviate } \\
\text { costs on the population. } \\
\text { Boost confidence and } \\
\text { tackle market } \\
\text { dysfunctionalities. }\end{array}$ \\
\hline Jamaica & 17-Mar-20 & March 2020 & & & & 0 & 37 & 4.7 & $\begin{array}{l}\text { Sovereign } \\
\text { bonds }\end{array}$ & Outright & $\mathrm{N}$ & NA & & $\begin{array}{l}\text { Boost confidence and } \\
\text { tackle market } \\
\text { dysfunctionalities. }\end{array}$ \\
\hline Mauritius & 15-May-20 & & 0 & 2 & 0.4 & & & & $\begin{array}{l}\text { Private } \\
\text { securities }\end{array}$ & Outright & $\mathrm{N}$ & $Q$ & & $\begin{array}{l}\text { Support fiscal needs and } \\
\text { measures to alleviate } \\
\text { costs on the population. } \\
\text { Provide monetary } \\
\text { stimulus. }\end{array}$ \\
\hline Mauritius & 22-May-20 & & 1 & 60 & 12.8 & & & & $\begin{array}{l}\text { Sovereign } \\
\text { bonds }\end{array}$ & Grant & $Y$ & $Q$ & & $\begin{array}{l}\text { Support fiscal needs and } \\
\text { measures to alleviate } \\
\text { costs on the population. }\end{array}$ \\
\hline Mexico & 12-Mar-20 & & 7 & 140 & 0.7 & & & & $\begin{array}{l}\text { Sovereign } \\
\text { bonds }\end{array}$ & Swap & $\mathrm{N}$ & $Q$ & & $\begin{array}{l}\text { Boost confidence and } \\
\text { tackle market } \\
\text { dysfunctionalities. }\end{array}$ \\
\hline Mexico & 21-Apr-20 & & 5 & 100 & 0.5 & & & & $\begin{array}{l}\text { Private } \\
\text { securities }\end{array}$ & Repo & $\mathrm{N}$ & $\mathrm{Q}$ & & $\begin{array}{l}\text { Boost confidence and tackle } \\
\text { market dysfunctionalities. }\end{array}$ \\
\hline $\begin{array}{l}\text { Philippines } \\
38\end{array}$ & 10-Apr-20 & 24-Mar-2020 & & & & & & & $\begin{array}{l}\text { Sovereign } \\
\text { bonds }\end{array}$ & Outright & $\mathrm{N}$ & NA & & $\begin{array}{l}\text { Boost confidence and } \\
\text { tackle market } \\
\text { dysfunctionalities. }\end{array}$ \\
\hline Poland & 16-Mar-20 & 19-Mar-20 & & & & 26 & 104 & 5.2 & $\begin{array}{l}\text { Sovereign } \\
\text { bonds, } \\
\text { governme } \\
\text { nt- } \\
\text { guarantee } \\
\text { d debt } \\
\text { securities } \\
\end{array}$ & Outright & $\mathrm{N}$ & NA & & $\begin{array}{l}\text { Support fiscal needs and } \\
\text { measures to alleviate } \\
\text { costs on the population. } \\
\text { Boost confidence and } \\
\text { tackle market } \\
\text { dysfunctionalities. }\end{array}$ \\
\hline
\end{tabular}

${ }^{38}$ These non-standard measures were implemented as early as March 2020, but no official announcement was made until April 10. 


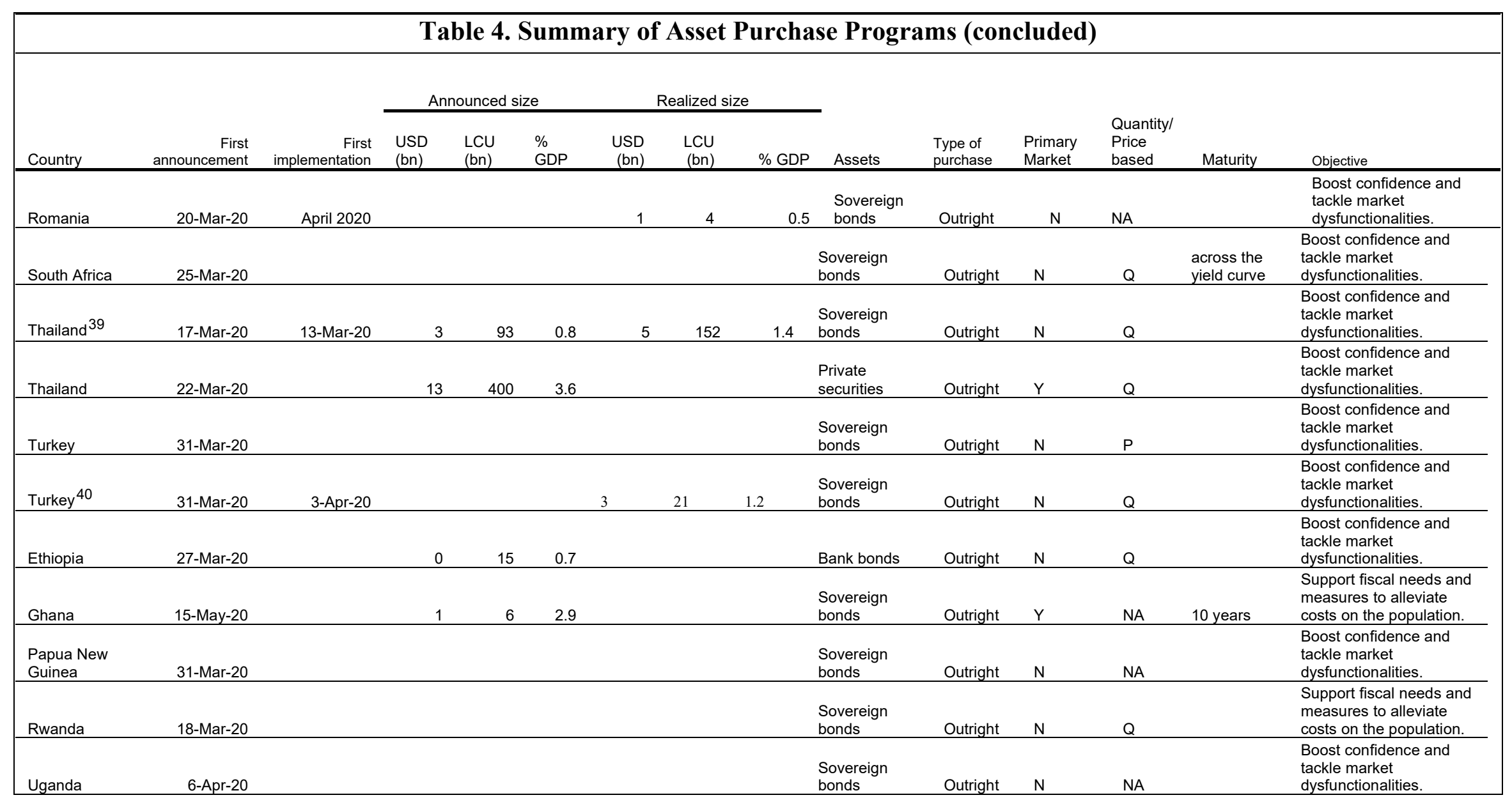

${ }^{39}$ The APP transaction data include also THB 64,120 million in purchases of Bank of Thailand bonds.

${ }^{40}$ This program involved the purchase of Government Domestic Debt Securities that they have bought from the Unemployment Insurance Fund by primary dealer banks. 


\section{EFFECTIVENESS OF UMP MEASURES IN EMS}

In this section, we assess empirically the effects of APP announcements on financial market variables as well as their channels of transmission. We confirm the findings of previous studies that APP announcements reduce bond yields and that this effect of the direct and signaling channels of transmission is larger in magnitude for APPs compared to that of policy rate cuts and stronger in EMs compared to AEs. We also find that the strength of the exchange rate channel depends on whether the APP announcement was made within a few days of a policy rate cut. In addition, as the objective of most APPs is to boost confidence and calm markets, we look at their second-round effects on external borrowing costs. ${ }^{41}$ If APP announcements managed to boost the confidence of investors, then the cost of borrowing should decrease as well, or at least level off. However, we find that this is not always the case.

We use an event study methodology to study the effects of APP announcements in our sample of 15 EMs and 8 small AEs. ${ }^{42}$ This methodology allows us to study the one, two and three-day impact of the APP announcements, where we also look at announcements that coincide with a policy rate cut. In Annex IV, we present a second event study as well as a set of panel regressions to check whether the effects on the days of announcements hold when control variables are introduced. We do this because the impact of APP announcements on the main variables of interest might be influenced by other policy announcements as well as shocks that we have not captured in the analysis.

The first event study, following Hartley and Rebucci (2020), aims to assess the effect of APP announcements on sovereign bond yields, as well as the exchange rate. We also investigate the second-round effects of APP announcements and whether they managed to affect the cost of external borrowing. While Hartley and Rebucci (2020) consider only the impact of the first announcement of every new program, which are more likely to be a surprise, we consider subsequent announcement dates as well, similar to Gagnon et al. (2011). Considering all announcement dates is important because the majority of central banks that made consecutive APP announcements did so in order to adjust the size and/or scope of the program, target additional maturities, etc. and such information can provide valuable signals to the market participants.

\footnotetext{
${ }^{41}$ Exploring the effect of APP announcements on stress indicators (e.g., liquidity risk), tail risks, and market liquidity indicators (bid/ask spreads, volatility, market turnover, etc.) would be desirable given the objectives of many programs of addressing market dysfunctions. However, doing so faces data limitations for most EMDEs.

42 The EM sample size is constrained by the availability of financial variables of interest. Nearly all EMs included in the sample announced quantity-based programs involving purchases of sovereign bonds (in a few cases, Colombia, Hungary, and Thailand, the programs involved purchases of both sovereign and private securities). Chile is the only country where the APP was price-based, targeting bank bonds. Croatia did not specify whether the APP was price- or quantity based.
} 
The effects of announcements are studied using the following variables of interest: (i) yield curve-10-year bond yield; 5-year bond yield; 2-year bond yield; 6-month bond yield; and (ii) exchange rate (local currency per US dollar). In order to estimate the second-round effects on external funding costs, we look at the EMBI spread. Finally, we also consider the equity index and the corporate bond yields. ${ }^{43}$ The impact on the variables of interest are evaluated using daily data from Reuters, omitting weekend and official holiday dates.

We compute the 1,2, and 3-day change for each of the variables of interest, starting on the day prior to the announcement date, and divide it by the corresponding unconditional standard deviations. ${ }^{44}$ These standard deviations are computed using daily data from January 1, 2017 through the day prior to the announcement, allowing for a sample of about 1,000 observations, long enough to obtain reliable measures. We then test the null hypothesis that the APP announcements have no significant impact on the variables of interest. We consider multi, rather than only one-day windows, because asset prices might not react instantaneously and in full following a policy announcement.

The main findings for EMDEs are shown in Figures 15-17 (see also Annex III). The results are rather heterogeneous across countries as well as announcements. However, on average, the estimated effect is statistically significant and broadly consistent with that found in the literature and in particular the results of Hartley and Rebucci (2020), Arslan et al. (2020), as well as Sever et al. (2020). In contrast to previous studies which focused only on the 10-year bond yield, we also analyzed the impact of APPs on other maturities. For other maturities between 2 and 5 years, the announcements also had a negative and statistically significant multi-day effect on bond yields suggesting effectiveness of APPs across the yield curve. However, APP announcements that coincided with FX intervention were not effective in lowering borrowing costs: they had a positive and statistically significant effect on the 10year bond yield (Table III.1).

Quantity-based programs as well as programs focusing on government securities seem to be more effective in terms of reducing the bond yields. No other specific patterns emerged when considering whether the announcements with the following characteristics were more effective: (i) made jointly with other national authorities; (ii) part of a policy package; (iii) had a detailed communication; (iv) the $\mathrm{CB}$ made a single or multiple announcement; (v) made by a credible $\mathrm{CB}$; (vi) made by a transparent $\mathrm{CB}$; (vii) the type of the exchange rate regime, (viii) capital account openness; (ix) the share of non-resident investors. In some cases, the first APP announcement had the expected statistically significant and negative

\footnotetext{
${ }^{43}$ The results obtained from these variables are available upon request. The results for the equity index and corporate bond yields indicate significant heterogeneity across the sample and an inconclusive average median effect (Figure 16).

${ }^{44}$ This is similar to the approach employed by Hartley and Rebucci (2020). Vissing-Jorgensen and Krishnamurthy (2011) and Swanson (2011) use two-day windows, while Gagnon et al. (2011) use 1-day event windows.
} 
effect on the 10-year bond yield, which was also more pronounced compared to the effect of consecutive announcements. However, in other cases, subsequent announcements were more effective, or the first announcement was not effective at all. Therefore, it remains inconclusive whether initial announcements are more effective due to their "surprise effect."

The findings related to the effect of APP announcements on the bond yields, continue to hold when we exclude from the sample the announcements that coincide with a policy rate cut. Specifically, we exclude 9 APP announcements from the sample. As is illustrated in Figure 16 , this is the case not only for the 10-year bond yield, but for other maturities as well.

The results related to the exchange rate indicate that the strength of the exchange rate channel depends on whether the APP announcement was made within a few days of a policy rate cut. When all APP announcements are taken under consideration, the results are predominantly positive and statistically significant, indicating that most APP announcements resulted in exchange rate depreciation. However, a few central banks announced policy rate cuts just the day before or the same that that they also announced an APP (Chile, Indonesia, Mexico, Poland, and Thailand). Therefore, it is very likely that the depreciation of the exchange rate after the APP announcement is a spillover effect from the policy rate cut announced the previous day or a few days before. ${ }^{45}$ When the APP announcement dates that are close to a policy rate cut are excluded (following the existing literature), the results for the exchange rate effect are inconclusive and thus suggest a weaker exchange rate channel. Furthermore, similarly to the results related to the 10 -year bond yield, we could not identify any patterns (Table III. 2). ${ }^{46}$

Looking at the second-round effects, the announcements have predominantly a positive and statistically significant effect on the EMBI, although with a significant heterogeneity across the sample. This confirms the finding that the announcements were not able to calm the markets sufficiently and restore the confidence of international investors, thus reducing the cost of external borrowing. This finding still holds when the APP announcements that are close to a policy rate cut are excluded.

The same event study methodology applied to implementation instead of announcement dates yields broadly consistent results for the countries for which data is available. However, the sample is more limited as implementation dates are available only for 5 small EAs (Sweden, Canada, Australia, New Zealand, and Korea) and 6 EMs (Colombia, India, Thailand, Hungary, Croatia, and Poland).

\footnotetext{
${ }^{45}$ The authors also appreciate the fact that other factors, such as the effect of the pandemic as well as the country's macroeconomic fundamental may be at play, which we attempt to control for with the analysis in Annex IV.

${ }^{46}$ Additional results are available upon request.
} 
Finally, the event study with control variables as well as the panel regression, presented in Annex IV, broadly confirm the findings above (Annex IV). ${ }^{47}$ In addition, the panel regressions also reveal that APP announcement made by credible central banks are more effective (in terms of their impact on bond yields). We do not find evidence of the role of central bank transparency, the non-residential investment share, or the monetary regime and the exchange rate regime on the effectiveness of the APP. Interestingly, we also find that larger programs, as measured by the announced size as a share of GDP, as well as programs announced in countries with low monetary space are associated with smaller effects on the government 10-year bond markets.

As central banks often implemented both conventional and unconventional policies, we run the same event study analysis to estimate the effects of policy rate cut announcementsincluding those that coincide with APP announcements. We find that these policy rate cut announcements had negative and statistically significant multi-day effects on the bond yields across the maturity curve, mostly over the period mid-March to end-April. Overall, the impact of conventional monetary policy transmission to bond yields is slightly less than that of APPs (Table III.3). Looking into the second-round effects, the results show that policy rate cut announcements managed to reduce the cost of external borrowing as well as have the expected depreciating effect on the exchange rate.

This analysis does not evaluate the effectiveness of APP programs in EMDEs related to the support of market functioning. Such an analysis is suitable for future work as this was the stated objective for most of the programs in our database. Also important for future work would be an analysis of the longer-term impact of these measures.

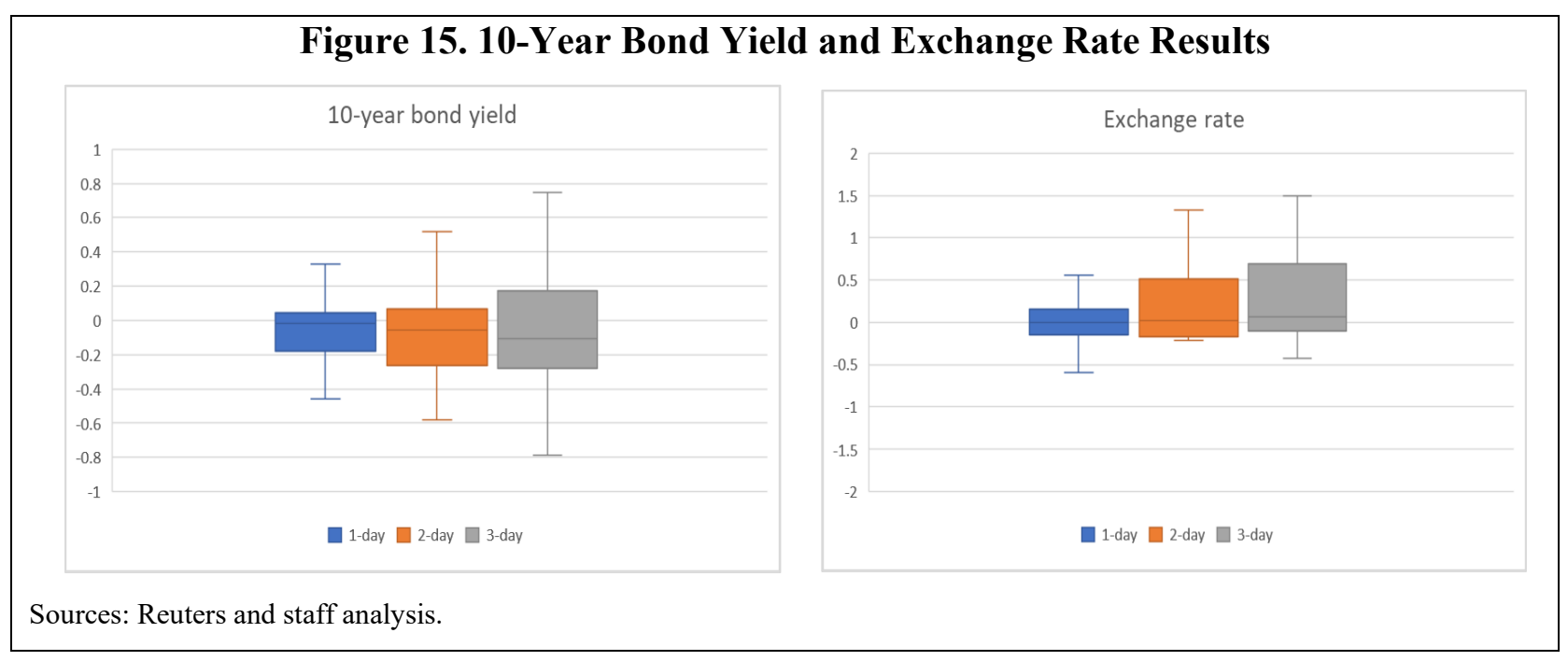

${ }^{47}$ The results of panel regressions find no significant effect of first announcements on the 10-year bond yield (Table IV.6, panel b). 

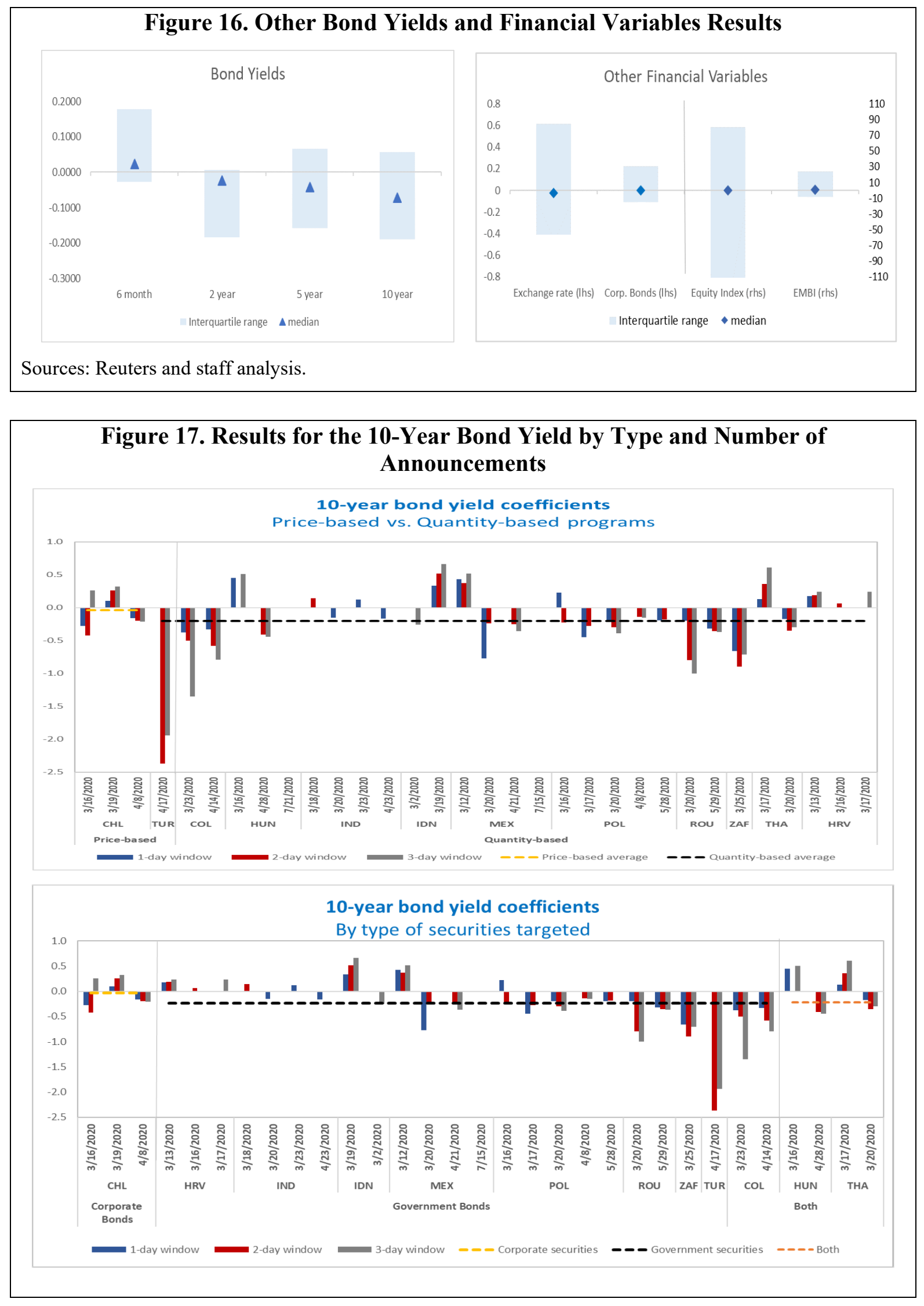

CInternational Monetary Fund. Not for Redistribution 


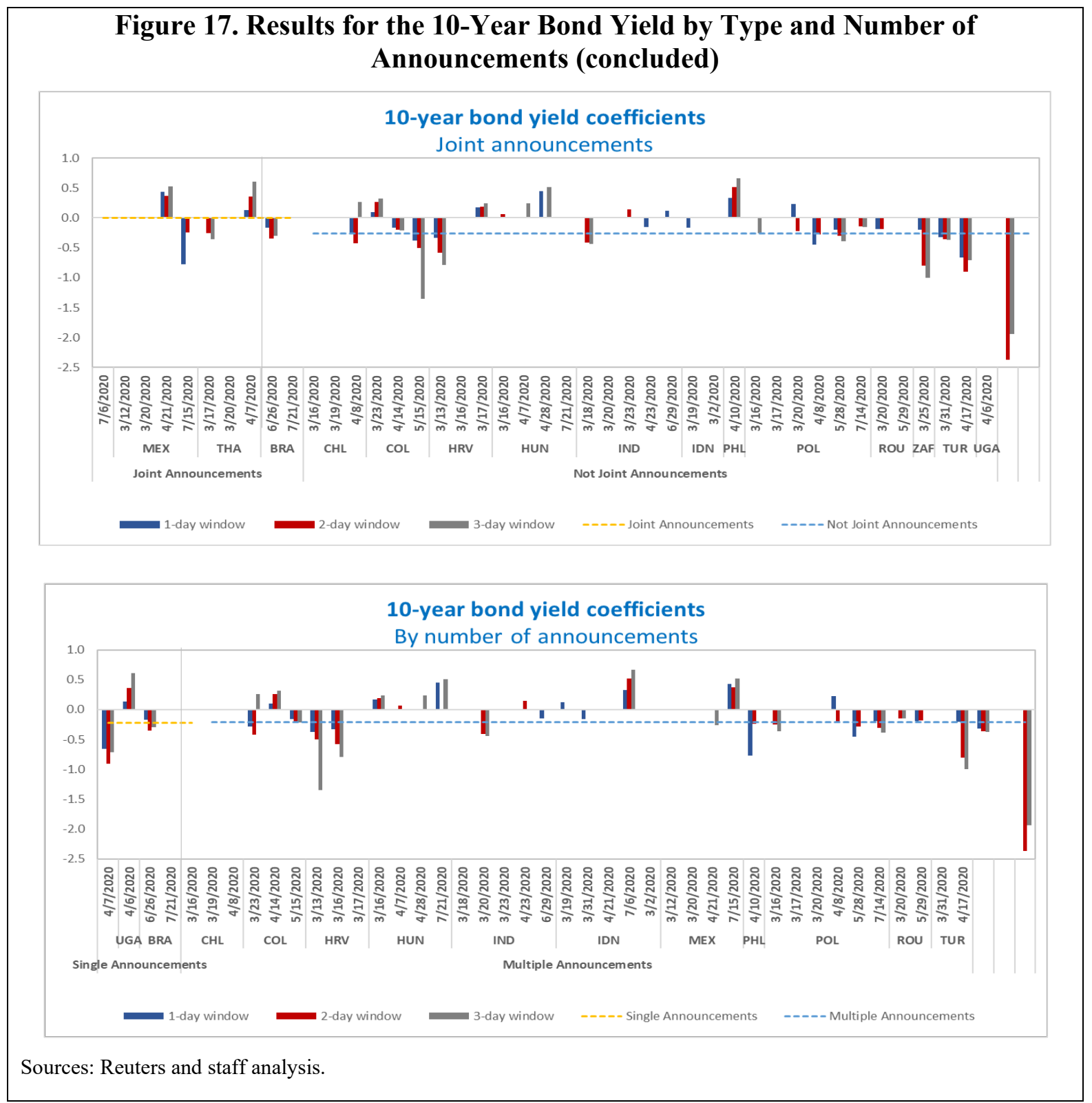

\section{Conclusions}

The COVID-19 crisis induced an unprecedented launch of unconventional monetary policy through asset purchase programs by emerging market and developing economies. Such measures have so far been largely used in advanced economies, and relatively little is known about their effectiveness in EMDEs, resulting in unease in policy circles regarding their use by these countries. This paper fills the gap by building a comprehensive database of APP announcements and implementations by a sample of 27 EMDEs and 8 small AEs from the onset of the crisis in March until August 2020. It also provides preliminary evidence of the effect of these APPs by country and announcement, as well as for the sample as a whole, in helping stabilize financial market prices. 
Specifically, our findings suggest that the APP announcements were effective in reducing the bond yields across different maturities, to a greater degree than to the CMP implemented in mid-March-end-April. However, APPs had little effects on exchange rates or external borrowing costs, after controlling for other factors (other policies or global factors). The implementation effects were similar in their impact to the announcement effects. Programs that coincided with FX intervention had the opposite expected effect on bond yields (positive and statistically significant). Some other program characteristics (announcements made jointly with other authorities, multiple announcements, size) also seemed to worsen outcomes. A few country specific factors e.g. CB credibility, high monetary policy space, low share of non-resident holdings of government bonds, seemed to improve the outcomes of APPs while other (CB transparency, monetary or exchange rate regime, foreign investment share) did not seem to have an impact.

Our results suggest that APPs can be usefully deployed by EMDEs in support of their macrofinancial stabilization objectives in the current COVID-19 crisis. However, more observations on their use, beyond the current crisis, and additional work will likely be needed in understanding the underpinnings and channels of the effectiveness of UMP in EMDEs to assess whether these tools could be also useful to EMDEs for normal times. 


\section{Annex I. Structure of the Database}

\section{A. Structure and Key Information in the UMP Database}

The database is organized by several identifying factors, per program and per announcement, including the following factors:

\section{Primary information related to the program, CB mandate, and involvement of other national authorities besides the $\mathrm{CB}$ :}

a. Identify if the press release announces a new program or if the CB has already used APP in the past. We also record whether the press release mentions/allows a change in the $\mathrm{CB}$ mandate.

b. Record if the notice is released by the $\mathrm{CB}$, national authorities, or jointly.

c. Record whether the press release mentions direct financing of the economy (captured by interventions on primary markets). We keep track of announcements in which the CB explicitly distances itself from direct financing.

2. Information on the program's objective(s):

a. Record the program's objective using direct quotes from the press release.

b. Classify the objectives into four main categories using textual analysis of the verbatims: "Support fiscal needs and measures to alleviate costs on the population", "Boost confidence and tackle market dysfunctionalities", "Provide monetary stimulus" and "Address exchange rate concerns".48

c. For the first three categories, we also record more details of the objectives. 49 For example, a program can have several objectives and sub-objectives falling under different categories.

\section{Information on the program type (price/quantity):}

a. Record whether the program is price-based and if the press release specifies/updates a price target.

\footnotetext{
${ }^{48}$ To that end, we identify groups of key words that structure the textual information. We group the selected key words by topic and recurring elements. We then organize the groups into broader categories to reflect the objectives of UMP from the literature that are being addressed in the press releases.

${ }^{49}$ For category 1 (fiscal needs etc.) we detail whether the objectives aim at "budget financing" (and related key words) or if they concern "Covid 19 support measures to the government or the population". For category 2 (DTC) we detail whether the objectives focused on boosting confidence and addressing market dysfunctionalities.
} 
b. Record whether the program is quantity based and if the press release specifies/updates a quantity target as well as the frequency of implementation.

c. Identify whether the press release refers to peculiar programs (swap, grant, SPV, etc.) and if the program is changing its operation procedure.

\section{Information on the program's main targets:}

a. Record whether the press release indicates targeting public or private securities (type of asset). and whether the CB is intervening on the primary or secondary markets.

b. Record if specific maturities are mentioned in the press release.

c. Record whether the press releases provides/updates information on the counterparties/credit rating targeted as well as whether the transaction is defined (outright, auctions, bilateral etc.).

\section{Information on the CB's communication style:}

a. Identify whether this is the first press release related to the APP. If no, we record the consecutive number of the announcement. We also record if the press release provides more information on an existing APP.

b. Record whether the press release provides information on expanding an existing the program or is announcing an APP in the future.

c. Record whether the APP announcement is done jointly with other CB measures:

i. Interest rate cuts;

ii. Repurchase agreements;

iii. Reduction in reserve requirements;

iv. Credit facilities/lending operations;

v. Foreign Exchange Interventions; and

vi. Capital flow measures.

\section{Information on APP implementation}

a. Record whether the press release specifies an implementation date, as well as whether the frequency of interventions is increased/scaled back.

b. Record whether the press-release announces more/less purchases, if so by how much and whether the press release terminates the program? 
In addition, the database contains information on the APP transactions made by the central banks, when available (date, market, size, price, issuer, yields, demand etc.)

\begin{tabular}{|c|}
\hline Table 1A Taxonomy of Asset Purchases Programs' Objectives \\
\hline 1. Support fiscal needs \\
\hline 2. Measures to alleviate costs on the population \\
\hline 3. Boost confidence and tackle market dysfunctionalities \\
\hline a) Enhance confidence, reduce stress, risk aversion... \\
\hline $\begin{array}{l}\text { b) Enhance transmission of monetary policy... } \\
\text { c) Ensure diffusion of credit/funding to the real economy... }\end{array}$ \\
\hline $\begin{array}{l}\text { d) Address high costs/asset prices... } \\
\text { e) Smooth price volatility... }\end{array}$ \\
\hline $\begin{array}{l}\text { f) Ensure financial market stability, address strains, increase market depth... } \\
\text { g) Ensure financial market efficiency, increase turnover... } \\
\text { h) Ensure financial market liquidity, reduce liquidity stress, liquidity stimulus... }\end{array}$ \\
\hline 4. Provide monetary stimulus \\
\hline $\begin{array}{l}\text { a) Monetary stimulus } \\
\text { b) Monetary and payment system stability }\end{array}$ \\
\hline 5. Address exchange rate concerns \\
\hline
\end{tabular}

To construct the taxonomy, we identify, across all quotes recorded as stated objectives, groups of key words that structure the textual information.

We then group the selected key words by topic and recurring words/elements ${ }^{50}$. We then organize the groups into broader categories to reflect the objectives of UMP that are commonly discussed in the literature and are being presently addressed in the press releases.

The companion excel spreadsheet providing information at the program level, provides the information on all verbatim and how they are related to the layers of the taxonomy.

\footnotetext{
${ }^{50} \mathrm{We}$ allow for some degree of flexibility as, for example, some statements explicitly define targeted institutions for example banks or corporations, whereas other statements mention more broadly financial or non-financial institutions.
} 
Annex II. Details on Taxonomy of Objectives

\begin{tabular}{|c|c|c|c|c|c|c|c|c|c|c|c|c|c|c|c|c|}
\hline Country & $\begin{array}{l}\text { Date Press } \\
\text { Release }\end{array}$ & Objective & 1 & 2 & $\begin{array}{l}3 \\
\mathrm{~A}\end{array}$ & $\begin{array}{l}3 \\
\mathrm{~B}\end{array}$ & $\begin{array}{l}3 \\
\mathrm{C}\end{array}$ & $\begin{array}{l}3 \\
\mathrm{D}\end{array}$ & $\begin{array}{l}3 \\
\mathrm{E}\end{array}$ & $\begin{array}{l}3 \\
\mathrm{~F}\end{array}$ & $\begin{array}{l}3 \\
\mathrm{G}\end{array}$ & $\begin{array}{l}3 \\
\mathrm{H}\end{array}$ & $\begin{array}{l}4 \\
\mathrm{~A}\end{array}$ & $\begin{array}{l}4 \\
\mathrm{~B}\end{array}$ & 5 & Link Announcement \\
\hline Angola & $15 / 04 / 2020$ & $\begin{array}{l}\text { broad package objective possible impacts of the } \\
\text { COVID-19 pandemic on the national economy, } \\
\text { with particular attention to the external accounts, } \\
\text { and its implications in the conduct of the monetary } \\
\text { and exchange rate policies }\end{array}$ & & $\mathrm{Y}$ & & & & & & & & & & & & $\begin{array}{l}\text { https://www.bna.ao/Conteudos/Arti } \\
\text { gos/detalhe artigo.aspx?idc }=175 \& \mathrm{i} \\
\text { dl=2\&idi }=16800\end{array}$ \\
\hline Angola & $07 / 05 / 2020$ & $\begin{array}{l}\text { to provide direct support to the productive sector } \\
\text { and to ease the pressure on the cash flow of these } \\
\text { companies, major employers, allowing them to } \\
\text { continue operating and, consequently, maintain } \\
\text { jobs. }\end{array}$ & & & & & $\mathrm{Y}$ & & & & & & & & & $\begin{array}{l}\text { https://www.bna.ao/Conteudos/Arti } \\
\text { gos/detalhe artigo.aspx?idc }=175 \& \mathrm{i} \\
\text { dl=2\&idi }=16831\end{array}$ \\
\hline Australia & $19 / 03 / 2020$ & $\begin{array}{l}\text { to help achieve [a price target for government bond } \\
\text { yield], as well as to address market dislocations. }\end{array}$ & & & & & & $\mathrm{Y}$ & & & $\mathrm{Y}$ & & & & & $\begin{array}{l}\text { https://www.rba.gov.au/mkt- } \\
\text { operations/announcements/rba- } \\
\text { purchases-of-government- } \\
\text { securities.html }\end{array}$ \\
\hline BEAC & $22 / 07 / 2020$ & $\begin{array}{l}\text { to support [members State of the BEAC] against } \\
\text { the economic consequences of the health crisis } \\
\text { associated to Covid } 19\end{array}$ & & Y & & & & & & & & & & & & $\begin{array}{l}\text { https://www.beac.int } / \text { wp- } \\
\text { content/uploads/2020/07/Communi } \\
\text { qu\%C3\%A9-de-Presse-CPM-extra- } \\
\text { 22072020.pdf }\end{array}$ \\
\hline BEAC & $22 / 07 / 2020$ & $\begin{array}{l}\text { to support [members State of the BEAC] against } \\
\text { the economic consequences of the health crisis } \\
\text { associated to Covid } 19 ; \text { to provide credit } \\
\text { establishments with the stable resources they need } \\
\text { to cover their activities in the medium and long run }\end{array}$ & & $\mathrm{Y}$ & & & & & & $\mathrm{Y}$ & & & & & & $\begin{array}{l}\frac{\text { https://www.beac.int } / \text { wp- }}{\text { content/uploads/2020/07/Communi }} \\
\text { qu\%C3\%A9-de-Presse-CPM-extra- } \\
\text { 22072020.pdf }\end{array}$ \\
\hline Bolivia & $27 / 03 / 2020$ & $\begin{array}{l}\text { to assist in emerging solutions to the pandemic that } \\
\text { afflicts the planet to sustain domestic demand }\end{array}$ & & $\mathrm{Y}$ & & & & & & & & & $\mathrm{Y}$ & & & $\begin{array}{l}\text { https://www.bcb.gob.bo/webdocs/fi } \\
\text { les_noticias/CP\%2014\%20COVID } \\
\text {-19\%20VERSION\%20FINAL.pdf }\end{array}$ \\
\hline Bolivia & $27 / 03 / 2020$ & $\begin{array}{l}\text { to assist in emerging solutions to the pandemic that } \\
\text { afflicts the planet to preserve the lives of Bolivians } \\
\text { and avoid the state of crisis they are experiencing } \\
\text { more developed societies, which were slow to } \\
\text { respond to the pandemic }\end{array}$ & & $\mathrm{Y}$ & & & & & & & & & & & & $\frac{\text { https://www.bcb.gob.bo/webdocs/fi }}{\text { les noticias/CP\%2014\%20COVID }}$ \\
\hline Brazil & $26 / 06 / 2020$ & $\begin{array}{l}\text { to provide liquidity to the private credit market, } \\
\text { allowing the sector to function better; to minimize } \\
\text { the effects of the pandemic on the private credit } \\
\text { market, where the impact was significant to } \\
\text { increase liquidity comprehensively }\end{array}$ & & $\mathrm{Y}$ & & & & & & & $\mathrm{Y}$ & $\mathrm{Y}$ & & & & $\begin{array}{l}\text { https://www.bcb.gov.br/detalhenoti } \\
\text { cia/464/noticia }\end{array}$ \\
\hline
\end{tabular}




\begin{tabular}{|c|c|c|c|c|c|c|c|c|c|c|c|c|c|c|c|c|}
\hline \multicolumn{17}{|c|}{ Annex II. Details on Taxonomy of Objectives (continued) } \\
\hline Country & $\begin{array}{l}\text { Date Press } \\
\text { Release }\end{array}$ & Objective & 1 & 2 & $\begin{array}{l}3 \\
\text { A }\end{array}$ & $\begin{array}{l}3 \\
\mathrm{~B}\end{array}$ & $\begin{array}{l}3 \\
\mathrm{C}\end{array}$ & $\begin{array}{l}3 \\
\mathrm{D}\end{array}$ & $\begin{array}{l}3 \\
\mathrm{E}\end{array}$ & $\begin{array}{l}3 \\
F\end{array}$ & $\begin{array}{l}3 \\
\mathrm{G}\end{array}$ & $\begin{array}{c}3 \\
\mathrm{H}\end{array}$ & $\begin{array}{l}4 \\
\mathrm{~A}\end{array}$ & $\begin{array}{l}4 \\
\mathrm{~B}\end{array}$ & 5 & \\
\hline Brazil & $21 / 07 / 2020$ & $\begin{array}{l}\text { to increase the effectiveness of BC interventions in } \\
\text { the period of facing the economic effects of Covid- } \\
19 ;+ \text { side objective address the need to create } \\
\text { transparent and secure conditions to increase the } \\
\text { supply of credit and to give effectiveness to the } \\
\text { BC's actions aimed at promptly facing the impacts } \\
\text { of the pandemic. in the national economy, for the } \\
\text { benefit of the real productive sector, employment } \\
\text { and the income of the Brazilian worker }\end{array}$ & & & & $\mathrm{Y}$ & $\mathrm{Y}$ & & & & & & & & & $\begin{array}{l}\text { https://www.bcb.gov.br/detalhenoti } \\
\text { cia/471/noticia }\end{array}$ \\
\hline $\begin{array}{l}\text { Cabo } \\
\text { Verde }\end{array}$ & $26 / 03 / 2020$ & $\begin{array}{l}\text { to mitigate the impact of the new coronavirus on } \\
\text { the national economy to assist any emergency } \\
\text { programs to promote disposable income to families } \\
\text { and companies }\end{array}$ & & $\mathrm{Y}$ & & & & & & & & & & & & $\begin{array}{l}\text { https://www.bcv.cv/pt/O\%20Banco } \\
\text { Sala } \% 20 \mathrm{de} \% 20 \text { Imprensa/Arquivo/ } \\
\text { Paginas/Confer\%C3\%AAncia-de- } \\
\text { Imprensa-26-de-marco-2020.aspx } \\
\end{array}$ \\
\hline Canada & $13 / 03 / 2020$ & $\begin{array}{l}\text { [CB statement] to support the continuous } \\
\text { functioning of financial markets ; [MoF statement }] \\
\text { support a key funding market for small- and } \\
\text { medium-size businesses at a time when they may } \\
\text { have increased funding needs and credit conditions } \\
\text { are tightening }\end{array}$ & & & & & & & & & $\mathrm{Y}$ & & & & & $\begin{array}{l}\text { https://www.canada.ca/en/departme } \\
\text { nt-finance/news/2020/03/canada- } \\
\text { outlines-measures-to-support-the- } \\
\text { economy-and-the-financial- } \\
\text { sector.html }\end{array}$ \\
\hline Canada & $16 / 03 / 2020$ & $\begin{array}{l}\text { so that this important funding [mortgage] market } \\
\text { continues to function well [CB statement, link 2] to } \\
\text { provide support to the Canada Mortgage Bond } \\
\text { (CMB) market }\end{array}$ & & & & & & & & & $\mathrm{Y}$ & & & & & $\underline{\text { https://www.bankofcanada.ca/2020 }}$ \\
\hline Canada & $24 / 03 / 2020$ & $\begin{array}{l}\text { to support the liquidity and efficiency of provincial } \\
\text { government funding markets. }\end{array}$ & & & & & & & & & $\mathrm{Y}$ & $\mathrm{Y}$ & & & & $\begin{array}{l}\text { https://www.bankofcanada.ca/2020 } \\
\text { /03/bank-canada-announces-new- } \\
\text { program-support-provincial- } \\
\text { funding-markets/ }\end{array}$ \\
\hline Canada & $27 / 03 / 2020$ & $\begin{array}{l}\text { to address strains in the Government of Canada } \\
\text { bond market and to enhance the effectiveness of all } \\
\text { other actions taken so far provide significant } \\
\text { support to the liquidity and efficiency of the } \\
\text { government bond market, reducing the need for } \\
\text { these fiscal agent operations }\end{array}$ & & & & & & & & & $\mathrm{Y}$ & $\mathrm{Y}$ & & & & $\begin{array}{l}\text { https://www.bankofcanada.ca/2020 } \\
\text { /03/operational-details-for-the- } \\
\text { secondary-market-purchases-of- } \\
\text { government-of-canada-securities/ }\end{array}$ \\
\hline Canada & $27 / 03 / 2020$ & $\begin{array}{l}\text { to support the continuous functioning of financial } \\
\text { markets }\end{array}$ & & & & & & & & & Y & & & & & $\begin{array}{l}\frac{\text { https://www.bankofcanada.ca/2020 }}{\text { /03/bank-of-canada-to-introduce-a- }} \\
\text { commercial-paper-purchase- } \\
\text { program/ }\end{array}$ \\
\hline
\end{tabular}




\begin{tabular}{|c|c|c|c|c|c|c|c|c|c|c|c|c|c|c|c|c|}
\hline \multicolumn{17}{|c|}{ Annex II. Details on Taxonomy of Objectives (continued) } \\
\hline Country & $\begin{array}{l}\text { Date Press } \\
\text { Release }\end{array}$ & Objective & 1 & 2 & $\begin{array}{l}3 \\
\text { A }\end{array}$ & $\begin{array}{l}3 \\
\text { B }\end{array}$ & $\begin{array}{l}3 \\
\mathrm{C}\end{array}$ & $\begin{array}{l}3 \\
\mathrm{D}\end{array}$ & $\begin{array}{l}3 \\
\mathrm{E}\end{array}$ & $\begin{array}{l}3 \\
F\end{array}$ & $\begin{array}{l}3 \\
\mathrm{G}\end{array}$ & $\begin{array}{c}3 \\
\mathrm{H}\end{array}$ & $\begin{array}{l}4 \\
\mathrm{~A}\end{array}$ & $\begin{array}{l}4 \\
\text { B }\end{array}$ & 5 & \\
\hline Canada & $31 / 03 / 2020$ & $\begin{array}{l}\text { help support the flow of credit to the economy by } \\
\text { alleviating strains in a key short-term financing } \\
\text { market serving a wide range of firms and public } \\
\text { authorities. }\end{array}$ & & & & & $\mathrm{Y}$ & & & & & & & & & $\begin{array}{l}\text { https://www.bankofcanada.ca/2020 } \\
\text { /03/operational-details- } \\
\text { commercial-paper-purchase- } \\
\text { program/ }\end{array}$ \\
\hline Canada & $09 / 04 / 2020$ & $\begin{array}{l}\text { to support the liquidity and well-functioning of } \\
\text { financial markets. }\end{array}$ & & & & & & & & & $\mathrm{Y}$ & $\mathrm{Y}$ & & & & $\begin{array}{l}\text { https://www.bankofcanada.ca/2020 } \\
\text { /04/temporary-changes- } \\
\text { government-canada-securities- } \\
\text { auction/ }\end{array}$ \\
\hline Canada & $15 / 04 / 2020$ & $\begin{array}{l}\text { to support the liquidity and proper functioning of } \\
\text { the corporate debt market; strengthens the pass- } \\
\text { through of monetary policy actions to borrowers ; } \\
\text { To support the flow of credit for corporate issuers } \\
\text { in Canada }\end{array}$ & & & & $\mathrm{Y}$ & $\mathrm{Y}$ & & & & & $\mathrm{Y}$ & & & & $\begin{array}{l}\frac{\text { https://www.bankofcanada.ca/2020 }}{\text { /04/bank-canada-introduce- }} \\
\text { corporate-bond-purchase-program/ }\end{array}$ \\
\hline Canada & $15 / 04 / 2020$ & $\begin{array}{l}\text { to support continued liquidity and efficient } \\
\text { functioning of the federal government's treasury } \\
\text { bill program }\end{array}$ & & & & & & & & & $\mathrm{Y}$ & Y & & & & $\begin{array}{l}\text { https://www.bankofcanada.ca/2020 } \\
\text { /04/bank-canada-announces- } \\
\text { increase-amount-government- } \\
\text { canada-treasury-bills/ }\end{array}$ \\
\hline Canada & $15 / 04 / 2020$ & $\begin{array}{l}\text { to further support the liquidity and efficiency of } \\
\text { provincial government funding markets ; to } \\
\text { maintain well-functioning provincial funding } \\
\text { markets in the face of significant demands for } \\
\text { funding as governments implement their } \\
\text { emergency measures, and businesses and } \\
\text { households seek to bridge this difficult period. }\end{array}$ & & & & & $\mathrm{Y}$ & & & & $\mathrm{Y}$ & $\mathrm{Y}$ & & & & $\begin{array}{l}\text { https://www.bankofcanada.ca/2020 } \\
\text { p04/bank-canada-introduce- } \\
\text { provincial-bond-purchase-program/ }\end{array}$ \\
\hline Canada & $30 / 04 / 2020$ & $\begin{array}{l}\text { help support the liquidity and efficiency of } \\
\text { provincial government funding markets }\end{array}$ & & & & & & & & & $\mathrm{Y}$ & $\mathrm{Y}$ & & & & $\begin{array}{l}\frac{\text { https://www.bankofcanada.ca/2020 }}{\text { /04/operational-details-provincial- }} \\
\text { bond-purchase-program/ }\end{array}$ \\
\hline Canada & $19 / 05 / 2020$ & $\begin{array}{l}\text { support the liquidity and proper functioning of the } \\
\text { corporate debt market; [associated link to more } \\
\text { details:] strengthens the pass-through of monetary } \\
\text { policy actions to borrowers }\end{array}$ & & & & $\mathrm{Y}$ & & & & & $\mathrm{Y}$ & $\mathrm{Y}$ & & & & $\begin{array}{l}\frac{\text { https://www.bankofcanada.ca/2020 }}{\text { /05/operational-details-corporate- }} \\
\text { bond-purchase-program/ }\end{array}$ \\
\hline Canada & $20 / 05 / 2020$ & $\begin{array}{l}\text { to support the well-functioning of this segment of } \\
\text { the Government of Canada securities market }\end{array}$ & & & & & & & & & $\mathrm{Y}$ & & & & & $\begin{array}{l}\text { https://www.bankofcanada.ca/2020 } \\
\text { 105/operational-details-upcoming- } \\
\text { secondary-market-purchases-real- } \\
\text { return-bonds/ }\end{array}$ \\
\hline Chile & $19 / 03 / 2020$ & $\begin{array}{l}\text { to contain the effects of high volatility events in } \\
\text { the fixed income market }\end{array}$ & & & & & & & $\mathrm{Y}$ & $\mathrm{Y}$ & & & & & & $\begin{array}{l}\text { https://www.bcentral.cl/en/content/ } \\
\text {-/details/banco-central-de-chile- } \\
\text { informa-condiciones-del-programa- } \\
\text { de-compra-de-bonos-bancarios- } \\
\text { anunciado-en-la-reunion-especial- } \\
\text { de-politica-monetaria }\end{array}$ \\
\hline
\end{tabular}




\begin{tabular}{|c|c|c|c|c|c|c|c|c|c|c|c|c|c|c|c|c|}
\hline \multicolumn{17}{|c|}{ Annex II. Details on Taxonomy of Objectives (continued) } \\
\hline Country & $\begin{array}{l}\text { Date Press } \\
\text { Release }\end{array}$ & Objective & 1 & 2 & $\begin{array}{l}3 \\
\mathrm{~A}\end{array}$ & $\begin{array}{l}3 \\
\mathrm{~B}\end{array}$ & $\begin{array}{l}3 \\
\mathrm{C}\end{array}$ & $\begin{array}{l}3 \\
\mathrm{D}\end{array}$ & $\begin{array}{l}3 \\
\mathrm{E}\end{array}$ & $\begin{array}{l}3 \\
\mathrm{~F}\end{array}$ & $\begin{array}{l}3 \\
\mathrm{G}\end{array}$ & $\begin{array}{l}3 \\
\mathrm{H}\end{array}$ & $\begin{array}{l}4 \\
\mathrm{~A}\end{array}$ & $\begin{array}{l}4 \\
\mathrm{~B}\end{array}$ & 5 & \\
\hline Chile & 08/04/2020 & $\begin{array}{l}\text { To facilitate the normal flow of credit and the } \\
\text { proper functioning of markets }\end{array}$ & & & Y & & $\mathrm{Y}$ & & & & Y & & & & & 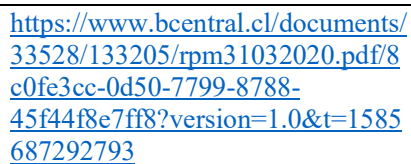 \\
\hline China & $01 / 06 / 2020$ & $\begin{array}{l}\text { to have a multiplier effect, so that small and micro } \\
\text { enterprises can really feel the changes when } \\
\text { applying for loans, and greatly increase the } \\
\text { proportion of credit loans issued by small and } \\
\text { micro enterprises }\end{array}$ & & & & & Y & & & & & & & & & $\frac{\underline{h t t p: / / w w w . p b c . g o v . c n / g o u t o n g j i a o ~}}{\text { liu/113456/113469/4033015/index. }}$ \\
\hline Colombia & $23 / 03 / 2020$ & $\begin{array}{l}\text { to facilitate the proper functioning of the financial } \\
\text { markets }\end{array}$ & & & & & & & & & Y & & & & & $\begin{array}{l}\text { https://www.banrep.gov.co/es/banc } \\
\text { o-republica-inyecta-liquidez- } \\
\text { permanente-economia-realizando- } \\
\text { compras-titulos-deuda-publica-y }\end{array}$ \\
\hline Colombia & $23 / 03 / 2020$ & $\begin{array}{l}\text { to facilitate the proper functioning of the financial } \\
\text { markets }\end{array}$ & & & & & & & & & Y & & & & & $\begin{array}{l}\text { https://www.banrep.gov.co/es/banc } \\
\text { o-republica-inyecta-liquidez- } \\
\text { permanente-economia-realizando- } \\
\text { compras-titulos-deuda-publica-y }\end{array}$ \\
\hline Colombia & $14 / 04 / 2020$ & $\begin{array}{l}\text { strengthen the liquidity of the public debt market } \\
\text { and increase the supply of liquidity. }\end{array}$ & & & & & & & & & & $\mathrm{Y}$ & & & & $\begin{array}{l}\text { https://www.banrep.gov.co/es/banc } \\
\text { o-republica-inyecta-liquidez- } \\
\text { permanente-economia-mediante- } \\
\text { reduccion-del-encaje-y-refuerza-su }\end{array}$ \\
\hline $\begin{array}{l}\text { Costa } \\
\text { Rica }\end{array}$ & $15 / 04 / 2020$ & $\begin{array}{l}\text { mitigate [systemic liquidity stress] and contribute } \\
\text { to preserving the stability of the financial system } \\
\text { aimed at providing liquidity, supporting the proper } \\
\text { functioning of payment systems and financial } \\
\text { markets, and seeking an effective transmission of } \\
\text { monetary policy }\end{array}$ & & & $\mathrm{Y}$ & Y & & & & $\mathrm{Y}$ & Y & $\mathrm{Y}$ & & $\mathrm{Y}$ & & $\begin{array}{l}\text { https://www.bccr.fi.cr/seccion- } \\
\text { noticias/Noticia/CPrensa_Mercado } \\
\text { secundario } 15 \text { 04 2020.aspx }\end{array}$ \\
\hline Croatia & $13 / 03 / 2020$ & $\begin{array}{l}\text { maintaining stability in the market of government } \\
\text { securities }\end{array}$ & & & & & & & & $\mathrm{Y}$ & & & & & & $\begin{array}{l}\text { https://www.hnb.hr/en/-/savjet- } \\
\text { hnb-a-hrvatska-narodna-banka- } \\
\text { najavljuje-strukturnu-operaciju-i- } \\
\text { zapocinje-kupovati-obveznice-rh } \\
\end{array}$ \\
\hline
\end{tabular}




\begin{tabular}{|c|c|c|c|c|c|c|c|c|c|c|c|c|c|c|c|c|}
\hline \multicolumn{17}{|c|}{ Annex II. Details on Taxonomy of Objectives (continued) } \\
\hline Country & $\begin{array}{l}\text { Date Press } \\
\text { Release }\end{array}$ & Objective & 1 & 2 & $\begin{array}{l}3 \\
\mathrm{~A}\end{array}$ & $\begin{array}{l}3 \\
\mathrm{~B}\end{array}$ & $\begin{array}{l}3 \\
\mathrm{C}\end{array}$ & $\begin{array}{l}3 \\
\mathrm{D}\end{array}$ & $\begin{array}{l}3 \\
\mathrm{E}\end{array}$ & $\begin{array}{l}3 \\
\mathrm{~F}\end{array}$ & $\begin{array}{l}3 \\
\mathrm{G}\end{array}$ & $\begin{array}{l}3 \\
\mathrm{H}\end{array}$ & $\begin{array}{l}4 \\
\text { A }\end{array}$ & $\begin{array}{l}4 \\
\mathrm{~B}\end{array}$ & 5 & \\
\hline Croatia & $17 / 03 / 2020$ & $\begin{array}{l}\text { to maintain the stability of the government } \\
\text { securities market. }\end{array}$ & & & & & & & & $\mathrm{Y}$ & & & & & & $\begin{array}{l}\text { https://www.hnb.hr/en/-/savjet- } \\
\text { hnb-a-kupnja-i-prodaja- } \\
\text { vrijednosnih-papira-rh-otvorena- } \\
\text { za-mirovinske-i-investicijske- } \\
\text { fondove-i-osiguravajuca-drustva }\end{array}$ \\
\hline Egypt & $21 / 03 / 2020$ & $\begin{array}{l}\text { support asset prices amid sustained market } \\
\text { volatility caused by the covid-19 outbreak }\end{array}$ & & & & & & $\mathrm{Y}$ & $\mathrm{Y}$ & & & & & & & $\begin{array}{l}\frac{\text { https://enterprise.press/stories/2020 }}{\text { /03/23/egypt-goes-full-kuroda-cbe- }} \\
\text { to-directly-purchase-equities-in-a- } \\
\text { bid-to-stem-egx-sell-off-13698/ ; } \\
\text { https://www.presidency.eg/en/\%D9 } \\
\text { \%82\%D8\%B3\%D9\%85- } \\
\text { \%D8\%A7\%D9\%84\%D8\%A3\%D8 } \\
\text { \%AE\%D8\%A8\%D8\%A7\%D }\end{array}$ \\
\hline Ethiopia & $27 / 03 / 2020$ & $\begin{array}{l}\text { [Reuters' quote] to provide debt relief and } \\
\text { additional loans to their customers in need [May } \\
15 \text { PM statement:] to address the expected liquidity } \\
\text { shortage from expected lower deposits and loan } \\
\text { collection, and to make available working capital } \\
\text { for sector }\end{array}$ & & & & & $\mathrm{Y}$ & & & & & $\mathrm{Y}$ & & & & $\begin{array}{l}\text { https://www.reuters.com/article/hea } \\
\text { lth-coronavirus-ethiopia- } \\
\text { economy/update-1-national-bank- } \\
\text { of-ethiopia-to-inject-450-million- } \\
\text { as-liquidity-for-private-banks- } \\
\text { idUSL8N2BK4FM }\end{array}$ \\
\hline Ghana & $15 / 05 / 2020$ & budget financing & $\mathrm{Y}$ & & & & & & & & & & & & & $\begin{array}{l}\text { https://www.bog.gov.gh/wp- } \\
\text { content/uploads/2020/05/MPC- } \\
\text { Press-Release-15th-May-2020- } \\
\text { 2.pdf }\end{array}$ \\
\hline Hungary & $16 / 03 / 2020$ & to increase bank liquidity & & & & & & & & & & $\mathrm{Y}$ & & & & $\begin{array}{l}\text { https://www.mnb.hu/en/monetary- } \\
\text { policy/the-monetary-council/press- } \\
\text { releases/2020/press-release-on-the- } \\
\text { monetary-council-meeting-of-24- } \\
\text { march-2020 }\end{array}$ \\
\hline Hungary & $07 / 04 / 2020$ & $\begin{array}{l}\text { strengthen the liquidity of the public debt market } \\
\text { and increase the liquidity supply. }\end{array}$ & & & & & & & & & & $\mathrm{Y}$ & & & & $\begin{array}{l}\text { https://www.mnb.hu/en/monetary- } \\
\text { policy/the-monetary-council/press- } \\
\text { releases/2020/press-release-on-the- } \\
\text { monetary-council-meeting-of-7- } \\
\text { april-2020 }\end{array}$ \\
\hline Hungary & $07 / 04 / 2020$ & $\begin{array}{l}\text { improve the long-term supply of funding to the } \\
\text { banking sector }\end{array}$ & & & & & & & & & & $\mathrm{Y}$ & & & & $\begin{array}{l}\text { https://www.mnb.hu/en/monetary- } \\
\text { policy/the-monetary-council/press- } \\
\text { releases/2020/press-release-on-the- } \\
\text { monetary-council-meeting-of-7- } \\
\text { april-2020 }\end{array}$ \\
\hline
\end{tabular}




\begin{tabular}{|c|c|c|c|c|c|c|c|c|c|c|c|c|c|c|c|c|}
\hline \multicolumn{17}{|c|}{ Annex II. Details on Taxonomy of Objectives (continued) } \\
\hline Country & $\begin{array}{l}\text { Date Press } \\
\text { Release }\end{array}$ & Objective & 1 & 2 & $\begin{array}{l}3 \\
\mathrm{~A}\end{array}$ & $\begin{array}{l}3 \\
\mathrm{~B}\end{array}$ & $\begin{array}{l}3 \\
\mathrm{C}\end{array}$ & $\begin{array}{l}3 \\
\mathrm{D}\end{array}$ & $\begin{array}{l}3 \\
\mathrm{E}\end{array}$ & $\begin{array}{l}3 \\
\mathrm{~F}\end{array}$ & $\begin{array}{l}3 \\
\mathrm{G}\end{array}$ & $\begin{array}{l}3 \\
\mathrm{H}\end{array}$ & $\begin{array}{l}4 \\
\mathrm{~A}\end{array}$ & $\begin{array}{l}4 \\
\mathrm{~B}\end{array}$ & 5 & \\
\hline Hungary & $28 / 04 / 2020$ & $\begin{array}{l}\text { to improve monetary policy transmission to } \\
\text { prevent damage to the monetary policy } \\
\text { transmission and manage economic and financial } \\
\text { risks arising from the coronavirus pandemic }\end{array}$ & & & & Y & & & & & & $\mathrm{Y}$ & & & & $\begin{array}{l}\text { https://www.mnb.hu/en/monetary- } \\
\text { policy/the-monetary-council/press- } \\
\text { releases/2020/press-release-on-the- } \\
\text { monetary-council-meeting-of-28- } \\
\text { april-2020 }\end{array}$ \\
\hline Hungary & $28 / 04 / 2020$ & $\begin{array}{l}\text { to improve the long-term supply of funding to the } \\
\text { banking sector to prevent damage to the monetary } \\
\text { policy transmission and manage economic and } \\
\text { financial risks arising from the coronavirus } \\
\text { pandemic }\end{array}$ & & & & $\mathrm{Y}$ & & & & & & $\mathrm{Y}$ & & & & $\begin{array}{l}\text { https://www.mnb.hu/en/monetary- } \\
\text { policy/the-monetary-council/press- } \\
\text { releases/2020/press-release-on-the- } \\
\text { monetary-council-meeting-of-28- } \\
\text { april-2020 }\end{array}$ \\
\hline Hungary & $21 / 07 / 2020$ & $\begin{array}{l}\text { to improve monetary policy transmission; to } \\
\text { support an extension in the maturity structure of } \\
\text { government debt; consider the government } \\
\text { securities purchase program as a safety net, which } \\
\text { it intends to use if and to the extent necessary. }\end{array}$ & . & & & Y & & $\mathrm{Y}$ & & & & & & & & $\begin{array}{l}\text { https://www.mnb.hu/en/monetary- } \\
\text { policy/the-monetary-council/press- } \\
\text { releases/2020/press-release-on-the- } \\
\text { monetary-council-meeting-of-21- } \\
\text { july-2020 }\end{array}$ \\
\hline Iceland & $23 / 03 / 2020$ & $\begin{array}{l}\text { ensure that looser monetary policy is properly } \\
\text { communicated to households and businesses }\end{array}$ & & & & $\mathrm{Y}$ & & & & & & & & & & $\begin{array}{l}\text { https://www.sedlabanki.is/utgefid- } \\
\text { efni/frettir-og- } \\
\text { tilkynningar/frettasafn/frett/2020/0 } \\
\text { 3/23/Yfirlysing- } \\
\text { peningastefnunefndar-23.-mars- } \\
\text { 2020/ }\end{array}$ \\
\hline Iceland & $22 / 04 / 2020$ & $\begin{array}{l}\text { ensure that looser monetary policy is properly } \\
\text { communicated to households and businesses } \\
\text { [Policy is stated in accordance with the Bank's } \\
\text { Monetary Policy Committee's statement of } 23 \\
\text { March 2020] }\end{array}$ & & & & $\mathrm{Y}$ & & & & & & & & & & $\begin{array}{l}\text { https://www.sedlabanki.is/utgefid- } \\
\text { efni/frettir-og- } \\
\text { tilkynningar/frettasafn/frett/2020/0 } \\
\text { 4/22/Tilkynning-vegna-kaupa- } \\
\text { Sedlabanka-Islands-a- } \\
\text { skuldabrefum-rikissjods/ } \\
\end{array}$ \\
\hline India & $18 / 03 / 2020$ & $\begin{array}{l}\text { to ensure that all market segments remain liquid } \\
\text { and stable, and function normally }\end{array}$ & & & & & & & & $\mathrm{Y}$ & $\mathrm{Y}$ & $\mathrm{Y}$ & & & & $\begin{array}{l}\underline{\text { https://www.rbi.org.in/Scripts/BS }} \\
\underline{\text { PressReleaseDisplay.aspx?prid=49 }} \\
\underline{534}\end{array}$ \\
\hline India & $20 / 03 / 2020$ & $\begin{array}{l}\text { ensure that all market segments remain liquid and } \\
\text { stable, and function normally with adequate } \\
\text { liquidity and turnover }\end{array}$ & & & & & & & & $\mathrm{Y}$ & $\mathrm{Y}$ & $\mathrm{Y}$ & & & & $\begin{array}{l}\text { https://www.rbi.org.in/Scripts/BS } \\
\underline{\text { PressReleaseDisplay.aspx?prid }=4 \overline{9}}\end{array}$ \\
\hline
\end{tabular}




\begin{tabular}{|c|c|c|c|c|c|c|c|c|c|c|c|c|c|c|c|c|}
\hline \multicolumn{17}{|c|}{ Annex II. Details on Taxonomy of Objectives (continued) } \\
\hline Country & $\begin{array}{c}\text { Date Press } \\
\text { Release }\end{array}$ & Objective & 1 & 2 & $\begin{array}{l}3 \\
\text { A }\end{array}$ & $\begin{array}{l}3 \\
\mathrm{~B}\end{array}$ & $\begin{array}{l}3 \\
\mathrm{C}\end{array}$ & $\begin{array}{l}3 \\
\mathrm{D}\end{array}$ & $\begin{array}{l}3 \\
\mathrm{E}\end{array}$ & $\begin{array}{l}3 \\
F\end{array}$ & $\begin{array}{l}3 \\
\mathrm{G}\end{array}$ & $\begin{array}{c}3 \\
\mathrm{H}\end{array}$ & $\begin{array}{l}4 \\
\mathrm{~A}\end{array}$ & $\begin{array}{l}4 \\
\mathrm{~B}\end{array}$ & 5 & \\
\hline India & $23 / 03 / 2020$ & $\begin{array}{l}\text { ensure that all market segments remain liquid and } \\
\text { stable, and function normally with adequate } \\
\text { liquidity and turnover [Statement's objective } \\
\text { relates to press release dated March 20,2020.] }\end{array}$ & & & & & & & & Y & $\mathrm{Y}$ & $\mathrm{Y}$ & & & & $\begin{array}{l}\text { https://www.rbi.org.in/Scripts/BS } \\
\text { PressReleaseDisplay.aspx?prid }=49 \\
\underline{554}\end{array}$ \\
\hline Indonesia & $02 / 03 / 2020$ & $\begin{array}{l}\text { to maintain monetary and financial market } \\
\text { stability, including mitigating the risk of COVID- } \\
19 \text { and to minimize the risk of increasing volatility } \\
\text { in the Rupiah exchange rate. Triple intervention is } \\
\text { conducted so that the Rupiah exchange rate moves } \\
\text { according to its fundamentals and follows market } \\
\text { mechanisms }\end{array}$ & & $\mathrm{Y}$ & & & & & & $\mathrm{Y}$ & & & & $\mathrm{Y}$ & $\mathrm{Y}$ & $\begin{array}{l}\text { https://www.bi.go.id/id/ruang- } \\
\text { media/siaran- } \\
\text { pers/Pages/sp 221520.aspx }\end{array}$ \\
\hline Indonesia & $19 / 03 / 2020$ & $\begin{array}{l}\text { to maintain monetary and financial market } \\
\text { stability, including mitigating the risk of COVID- } \\
19 \text { and to minimize the risk of increasing volatility } \\
\text { in the Rupiah exchange rate. Triple intervention is } \\
\text { conducted so that the Rupiah exchange rate moves } \\
\text { according to its fundamentals and follows market } \\
\text { mechanisms }\end{array}$ & & $\mathrm{Y}$ & & & & & & Y & & & & $\mathrm{Y}$ & $\mathrm{Y}$ & $\begin{array}{l}\text { https://www.bi.go.id/id/ruang- } \\
\text { media/siaran- } \\
\text { pers/Pages/sp 222220.aspx }\end{array}$ \\
\hline Indonesia & $31 / 03 / 2020$ & $\begin{array}{l}\text { to assist the Government finance the handling of } \\
\text { the COVID-19 impact on financial system } \\
\text { stability. }\end{array}$ & & & & & & & & & & & & & & $\begin{array}{l}\text { https://www.bi.go.id/en/ruang- } \\
\text { media/siaran- } \\
\text { pers/Pages/sp 222620.aspx }\end{array}$ \\
\hline Indonesia & $21 / 04 / 2020$ & $\begin{array}{l}\text { This is needed as a source of funding for the } \\
\text { government in the context of national economic } \\
\text { recovery, including maintaining the sustainability } \\
\text { of state financial management including SUN and / } \\
\text { or SBSN issued in the context of the COVID-19 } \\
\text { pandemic. The purchase of SUN and / or SBSN in } \\
\text { the primary market is based on the BI principle as } \\
\text { the last resort in the event that the market capacity } \\
\text { is unable to absorb and / or causes a yield increase } \\
\text { that is too high. }\end{array}$ & $\mathrm{Y}$ & $\mathrm{Y}$ & & & & $\mathrm{Y}$ & & & & & & & & $\begin{array}{l}\text { https://www.bi.go.id/id/ruang- } \\
\text { media/info-terbaru/Pages/BI- } \\
\text { Terbitkan-Ketentuan-Pelaksanaan- } \\
\text { Lelang-SUN-dan-atau-SBSN- } \\
\text { Jangka-Panjang-di-Pasar- } \\
\text { Perdana.aspx }\end{array}$ \\
\hline Indonesia & $06 / 07 / 2020$ & $\begin{array}{l}\text { to share the burden (burden sharing) in carrying } \\
\text { out the handling of Covid-19 and national } \\
\text { economic recovery }\end{array}$ & $\mathrm{Y}$ & $\mathrm{Y}$ & & & & & & & & & & & & $\begin{array}{l}\text { https://www.kemenkeu.go.id/publi } \\
\text { kasi/siaran-pers/siaran-pers- } \\
\text { burden-sharing-pembiayaan- } \\
\text { penanganan-pandemi-covid-19- } \\
\text { antara-pemerintah-dan-bank- } \\
\text { sentral/ }\end{array}$ \\
\hline
\end{tabular}




\begin{tabular}{|c|c|c|c|c|c|c|c|c|c|c|c|c|c|c|c|c|}
\hline \multicolumn{17}{|c|}{ Annex II. Details on Taxonomy of Objectives (continued) } \\
\hline Country & $\begin{array}{l}\text { Date Press } \\
\text { Release }\end{array}$ & Objective & 1 & 2 & $\begin{array}{l}3 \\
\mathrm{~A}\end{array}$ & $\begin{array}{l}3 \\
\mathrm{~B}\end{array}$ & $\begin{array}{l}3 \\
\mathrm{C}\end{array}$ & $\begin{array}{l}3 \\
\mathrm{D}\end{array}$ & $\begin{array}{l}3 \\
\mathrm{E}\end{array}$ & $\begin{array}{l}3 \\
\mathrm{~F}\end{array}$ & $\begin{array}{l}3 \\
\mathrm{G}\end{array}$ & $\begin{array}{l}3 \\
\mathrm{H}\end{array}$ & $\begin{array}{l}4 \\
\mathrm{~A}\end{array}$ & $\begin{array}{l}4 \\
\mathrm{~B}\end{array}$ & 5 & \\
\hline Israel & $15 / 03 / 2020$ & $\begin{array}{l}\text { to ensure the smooth functioning of the } \\
\text { government bond market to moderate the abnormal } \\
\text { volatility and to increase the liquidity in the } \\
\text { financial markets where the various financial } \\
\text { institutions, businesses and households are } \\
\text { operating enhance the effectiveness of the } \\
\text { monetary policy }\end{array}$ & & & & $\mathrm{Y}$ & & & & $\mathrm{Y}$ & & $\mathrm{Y}$ & & & & $\begin{array}{l}\text { https://www.boi.org.i1/en/NewsAnd } \\
\text { Publications/PressReleases/Pages/1 } \\
\text { 5-03-2020.aspx }\end{array}$ \\
\hline Israel & $23 / 03 / 2020$ & $\begin{array}{l}\text { easing credit conditions in the economy and } \\
\text { supporting economic activity and financial stability } \\
\text { to influence bond yields in the market along the } \\
\text { entire unindexed and indexed curves, and to lower } \\
\text { the costs of longer-term credit for firms and } \\
\text { households, as a complementary tool to the short- } \\
\text { term interest rate policy. to moderate serious } \\
\text { volatility in bond yields that is caused by the lack } \\
\text { of liquidity in the financial markets, and to work } \\
\text { toward stabilizing the markets }\end{array}$ & & & & & $\mathrm{Y}$ & $\mathrm{Y}$ & Y & Y & & & & & & $\frac{\underline{\text { https://www.boi.org.i1/en/NewsAnd }}}{\text { Publications/PressReleases/Pages/2 }}$ \\
\hline Israel & $06 / 07 / 2020$ & $\begin{array}{l}\text { to ensure the continued orderly functioning of the } \\
\text { corporate bond market, and to strengthen the } \\
\text { passthrough from monetary policy to the credit } \\
\text { market, by reducing the interest rate at which } \\
\text { companies issue credit in the capital market, and } \\
\text { making additional sources of credit available for } \\
\text { all industries. }\end{array}$ & & & & $\mathrm{Y}$ & $\mathrm{Y}$ & $\mathrm{Y}$ & & & $\mathrm{Y}$ & & & & & $\begin{array}{l}\text { https://www.boi.org.il/en/NewsAnd } \\
\text { Publications/PressReleases/Pages/6 } \\
\text {-7-2020.aspx }\end{array}$ \\
\hline Jamaica & $17 / 03 / 2020$ & $\begin{array}{l}\text { To enable access to liquidity by all financial } \\
\text { institutions }\end{array}$ & & & & & & & & & & $\mathrm{Y}$ & & & & $\begin{array}{l}\text { http://www.boj.org.jm/uploads/new } \\
\text { s/boj_press_release - } \\
\text { access to liquidity.pdf }\end{array}$ \\
\hline Korea & $19 / 03 / 2020$ & stabilize bond market & . & & & & & & & $\mathrm{Y}$ & & & & & & $\begin{array}{l}\text { https://www.bok.or.kr/eng/bbs/E00 } \\
00628 / \text { view.do?nttId=10059459\& } \\
\text { menuNo=400025\&pageIndex }=1\end{array}$ \\
\hline Korea & $09 / 04 / 2020$ & to stabilize KTB market supply-demand conditions & & & & & & & & Y & & & & & & $\begin{array}{l}\underline{\mathrm{https}: / / \text { www.bok.or.kr/eng/bbs/E00 }} \\
\underline{\underline{00634 / \mathrm{view} \cdot \mathrm{do} \text { nttId=10057611\& }}} \\
\text { menuNo=400069\&pageIndex }=12\end{array}$ \\
\hline
\end{tabular}




\begin{tabular}{|c|c|c|c|c|c|c|c|c|c|c|c|c|c|c|c|c|}
\hline \multicolumn{17}{|c|}{ Annex II. Details on Taxonomy of Objectives (continued) } \\
\hline Country & $\begin{array}{l}\text { Date Press } \\
\text { Release }\end{array}$ & Objective & 1 & 2 & $\begin{array}{l}3 \\
\text { A }\end{array}$ & $\begin{array}{l}3 \\
\mathrm{~B}\end{array}$ & $\begin{array}{l}3 \\
\mathrm{C}\end{array}$ & $\begin{array}{l}3 \\
\mathrm{D}\end{array}$ & $\begin{array}{l}3 \\
\mathrm{E}\end{array}$ & $\begin{array}{l}3 \\
\mathrm{~F}\end{array}$ & $\begin{array}{l}3 \\
\mathrm{G}\end{array}$ & $\begin{array}{l}3 \\
\mathrm{H}\end{array}$ & $\begin{array}{l}4 \\
\text { A }\end{array}$ & $\begin{array}{l}4 \\
\mathrm{~B}\end{array}$ & 5 & \\
\hline Korea & $10 / 04 / 2020$ & $\begin{array}{l}\text { to expand liquidity supply channels to induce } \\
\text { smooth provision of credit to the real sector if } \\
\text { financial unrest deepens to encourage the smooth } \\
\text { flow of funds in the bond market, and thereby } \\
\text { promote financial market stability by improving } \\
\text { the liquidity of bank debentures issued by three } \\
\text { specialized banks, and reinforcing the basis for } \\
\text { demand to improve the collateral availability of } \\
\text { financial institutions and expand liquidity supply } \\
\text { channels for financial markets }\end{array}$ & & & & & $\mathrm{Y}$ & & & $\mathrm{Y}$ & & $\mathrm{Y}$ & & & & $\begin{array}{l}\underline{\text { https: } / / \text { www.bok.or.kr/eng } / \mathrm{bbs} / \mathrm{E} 00} \\
\text { 00634/view.do?nttId=10057611\& } \\
\text { menuNo=400069\&pageIndex }=8\end{array}$ \\
\hline Korea & $20 / 05 / 2020$ & $\begin{array}{l}\text { to calm a local debt market hammered by the } \\
\text { coronavirus pandemic }\end{array}$ & & & $\mathrm{Y}$ & & & & & $\mathrm{Y}$ & & & & & & $\begin{array}{l}\underline{\mathrm{https}: / / \mathrm{www} \cdot \text { bok.or.kr/eng } / \mathrm{bbs} / \mathrm{E} 00} \\
\underline{\text { 00628/view.do?nttId=10059459\& }} \\
\text { menuNo=400025\&pageIndex }=1\end{array}$ \\
\hline Mauritius & $22 / 05 / 2020$ & $\begin{array}{l}\text { to maintain the stability of the financial system and } \\
\text { mitigate any adverse impact on the economy in the } \\
\text { context of COVID19 to mitigate contagion of the } \\
\text { ongoing economic downturn to the banking sector, } \\
\text { thus limiting macro-financial risks }\end{array}$ & & $\mathrm{Y}$ & & & & & & $\mathrm{Y}$ & & & & & & $\begin{array}{l}\frac{\mathrm{https}: / / \text { www.bom.mu/sites/default/f }}{\text { iles/supporting_systemic_economic }} \\
\text { operators_and_financial_stability. } \\
\text { pdf }\end{array}$ \\
\hline Mauritius & $22 / 05 / 2020$ & $\begin{array}{l}\text { for the purpose of assisting Government in its } \\
\text { fiscal measures to stabilize the economy of } \\
\text { Mauritius }\end{array}$ & $\mathrm{Y}$ & & & & & & & & & & & & & $\begin{array}{l}\text { https://www.bom.mu/media/covid1 } \\
\text { 9-actions/covid-19-support- } \\
\text { programme-supporting-systemic- } \\
\text { economic-operators-and-financial- } \\
\text { stability }\end{array}$ \\
\hline Mauritius & $29 / 05 / 2020$ & $\begin{array}{l}\text { support and accelerate economic development and } \\
\text { build a value base for the current and future } \\
\text { generations of our country }\end{array}$ & & Y & & & & & & & & & & & & $\begin{array}{l}\text { https://www.bom.mu/sites/default/f } \\
\text { iles/statement_governor - } \\
29 \text { may 2020.pdf }\end{array}$ \\
\hline Mexico & $20 / 03 / 2020$ & $\begin{array}{l}\text { to ensure that participating financial institutions } \\
\text { contribute to the development of the government } \\
\text { securities market by engaging in debt placements, } \\
\text { providing liquidity to the market, and facilitating } \\
\text { the market price discovery process. }\end{array}$ & & & & & & & & & $\mathrm{Y}$ & $\mathrm{Y}$ & & & & $\begin{array}{l}\text { https://www.banxico.org.mx/public } \\
\text { ations-and-press/other- } \\
\text { announcements/\%7BE626A744- } \\
\text { 436D-2495-0969- } \\
\text { 3582C9571361\%7D.pdf }\end{array}$ \\
\hline
\end{tabular}




\begin{tabular}{|c|c|c|c|c|c|c|c|c|c|c|c|c|c|c|c|c|}
\hline \multicolumn{17}{|c|}{ Annex II. Details on Taxonomy of Objectives (continued) } \\
\hline Country & $\begin{array}{l}\text { Date Press } \\
\text { Release }\end{array}$ & Objective & 1 & 2 & $\begin{array}{l}3 \\
\text { A }\end{array}$ & $\begin{array}{l}3 \\
\mathrm{~B}\end{array}$ & $\begin{array}{l}3 \\
\mathrm{C}\end{array}$ & $\begin{array}{l}3 \\
\mathrm{D}\end{array}$ & $\begin{array}{l}3 \\
\mathrm{E}\end{array}$ & $\begin{array}{l}3 \\
\mathrm{~F}\end{array}$ & $\begin{array}{l}3 \\
G\end{array}$ & $\begin{array}{l}3 \\
\mathrm{H}\end{array}$ & $\begin{array}{l}4 \\
\mathrm{~A}\end{array}$ & $\begin{array}{l}4 \\
\mathrm{~B}\end{array}$ & 5 & \\
\hline Mexico & $21 / 04 / 2020$ & $\begin{array}{l}\text { To promote the proper functioning of the } \\
\text { government debt market }\end{array}$ & & & & & & & & & $\mathrm{Y}$ & & & & & $\begin{array}{l}\text { https://www.banxico.org.mx/public } \\
\text { ations-and-press/other- } \\
\text { announcements/\%7B6F7FECBA- } \\
\text { 44CB-6AA5-4E4B- } \\
\text { 269DDBD9B5A8\%7D.pdf }\end{array}$ \\
\hline Mexico & $21 / 04 / 2020$ & $\begin{array}{l}\text { to promote an orderly behavior of Mexico's debt } \\
\text { market; to provide liquidity for trading instruments } \\
\text { which, as a result of uncertainty and volatility, } \\
\text { have observed lower liquidity and impaired trading } \\
\text { conditions in the secondary market; to strengthen } \\
\text { the credit channel }\end{array}$ & & & & & $\mathrm{Y}$ & & & $\mathrm{Y}$ & $\mathrm{Y}$ & $\mathrm{Y}$ & & & & $\begin{array}{l}\text { https://www.banxico.org.mx/public } \\
\text { ations-and-press/other- } \\
\text { announcements/\%7B6F7FECBA- } \\
\text { 44CB-6AA5-4E4B- } \\
\text { 269DDBD9B5A8\%7D.pdf }\end{array}$ \\
\hline $\begin{array}{l}\text { New } \\
\text { Zealand }\end{array}$ & $20 / 03 / 2020$ & to support market functioning & & & & & & & & & $\mathrm{Y}$ & & & & & $\begin{array}{l}\text { https://www.rbnz.govt.nz/news/202 } \\
\text { 0/03/the-reserve-bank-is- } \\
\text { committed-to-ensuring-smooth- } \\
\text { market-functioning }\end{array}$ \\
\hline $\begin{array}{l}\text { New } \\
\text { Zealand }\end{array}$ & $23 / 03 / 2020$ & $\begin{array}{l}\text { provide further support to the economy, build } \\
\text { confidence, and keep interest rates on government } \\
\text { bonds low. leave enough liquidity for the New } \\
\text { Zealand government bond market to function } \\
\text { effectively }\end{array}$ & & & $\mathrm{Y}$ & & & $\mathrm{Y}$ & & & & $\mathrm{Y}$ & $\mathrm{Y}$ & & & $\begin{array}{l}\text { https://www.rbnz.govt.nz/markets- } \\
\text { and-payments/domestic- } \\
\text { markets/domestic-markets-media- } \\
\text { releases/reserve-bank-to-begin- } \\
\text { large-scale-asset-purchases-23- } \\
\text { march-2020 }\end{array}$ \\
\hline $\begin{array}{l}\text { New } \\
\text { Zealand }\end{array}$ & $13 / 06 / 2020$ & $\begin{array}{l}\text { to continue to reduce the cost of borrowing quickly } \\
\text { and sharply }\end{array}$ & & & Y & & & $\mathrm{Y}$ & & & & $\mathrm{Y}$ & Y & & & $\begin{array}{l}\text { https://www.rbnz.govt.nz/news/202 } \\
\text { 0/05/large-scale-asset-purchases- } \\
\text { expanded }\end{array}$ \\
\hline Norway & $3 / 16 / 20$ & $\begin{array}{l}\text { contribute to increased liquidity and access to } \\
\text { capital in the Norwegian bond market, where } \\
\text { larger companies typically raise their funding. }\end{array}$ & & & & & $\mathrm{Y}$ & & & & & $\mathrm{Y}$ & & & & $\begin{array}{l}\text { https://www.regjeringen.no/en/aktu } \\
\text { elt/nok-100-billion-worth-of- } \\
\text { guarantees-and-loans-in-crisis- } \\
\text { support-for-businesses/id2693668/ } \\
\end{array}$ \\
\hline Norway & $3 / 20 / 20$ & $\begin{array}{l}\text { make it easier for companies to secure the liquidity } \\
\text { they need in this challenging situation }\end{array}$ & & & & & $\mathrm{Y}$ & & & & & $\mathrm{Y}$ & & & & $\begin{array}{l}\text { https://www.regjeringen.no/en/aktu } \\
\text { elt/guarantee-and-loan- } \\
\text { programmes-improving-liquidity- } \\
\text { for-norwegian- } \\
\text { companies/id2694273/ }\end{array}$ \\
\hline
\end{tabular}




\begin{tabular}{|c|c|c|c|c|c|c|c|c|c|c|c|c|c|c|c|c|}
\hline \multicolumn{17}{|c|}{ Annex II. Details on Taxonomy of Objectives (continued) } \\
\hline Country & $\begin{array}{l}\text { Date Press } \\
\text { Release }\end{array}$ & Objective & 1 & 2 & $\begin{array}{l}3 \\
\mathrm{~A}\end{array}$ & $\begin{array}{l}3 \\
\mathrm{~B}\end{array}$ & $\begin{array}{l}3 \\
\mathrm{C}\end{array}$ & $\begin{array}{l}3 \\
\mathrm{D}\end{array}$ & $\begin{array}{l}3 \\
\mathrm{E}\end{array}$ & $\begin{array}{l}3 \\
F\end{array}$ & $\begin{array}{l}3 \\
\mathrm{G}\end{array}$ & $\begin{array}{l}3 \\
\mathrm{H}\end{array}$ & $\begin{array}{l}4 \\
\mathrm{~A}\end{array}$ & $\begin{array}{l}4 \\
\mathrm{~B}\end{array}$ & 5 & \\
\hline Norway & $3 / 29 / 20$ & $\begin{array}{l}\text { contribute to increased liquidity and capital in the } \\
\text { bond market.; help improve functioning of the } \\
\text { credit bond market. It will make it easier for big } \\
\text { companies to get the liquidity they need to } \\
\text { preserve jobs in the current difficult situation; to } \\
\text { stimulate other investors to participate in the bond } \\
\text { market. }\end{array}$ & . & & & & & & & & $\mathrm{Y}$ & $\mathrm{Y}$ & & & & $\begin{array}{l}\text { https://www.regjeringen.no/en/aktu } \\
\text { elt/mandate-established-for- } \\
\text { management-of-government-bond- } \\
\text { fund/id2695345/ }\end{array}$ \\
\hline $\begin{array}{l}\text { Papua } \\
\text { New } \\
\text { Guinea }\end{array}$ & $31 / 03 / 2020$ & $\begin{array}{l}\text { to provide liquidity to holders of [Treasury Bills or } \\
\text { Government Inscribed Stocks] }\end{array}$ & & & & & & & & & & $\mathrm{Y}$ & & & & $\begin{array}{l}\text { https://www.bankpng.gov.pg/wp- } \\
\text { content/uploads/2020/07/20200331 } \\
\text {-Policy-Response-on-Impact-of- } \\
\text { Corona-Virus4-full-page.pdf }\end{array}$ \\
\hline $\begin{array}{l}\text { Philippine } \\
\mathrm{s}\end{array}$ & $10 / 04 / 2020$ & $\begin{array}{l}\text { reassuring market participants of demand for GS } \\
\text { should they need to liquidate their holdings, thus } \\
\text { encouraging participation in the GS auctions }\end{array}$ & & & $\mathrm{Y}$ & & & & & & $\mathrm{Y}$ & & & & & $\begin{array}{l}\text { http://www.bsp.gov.ph/publications } \\
/ \text { media.asp?id=5352\&yr=2020 }\end{array}$ \\
\hline Poland & $16 / 03 / 2020$ & $\begin{array}{l}\text { as part of the structural operations that change the } \\
\text { long-term liquidity structure in the banking sector } \\
\text { and contribute to maintaining the liquidity in the } \\
\text { government bond secondary market }\end{array}$ & & & & & & & & & & Y & & & & $\begin{array}{l}\text { https://www.nbp.pl/en/aktualnosci/ } \\
\text { 2020/mpc_2020_03_17.pdf }\end{array}$ \\
\hline Poland & $08 / 04 / 2020$ & $\begin{array}{l}\text { changing the long-term liquidity structure in the } \\
\text { banking sector, ensuring the liquidity in secondary } \\
\text { markets for the purchased securities and enhancing } \\
\text { the impact of the NBP interest rate cuts on the } \\
\text { economy, i.e. strengthening the monetary policy } \\
\text { transmission }\end{array}$ & & & & Y & & & & & & $\mathrm{Y}$ & & & & $\begin{array}{l}\text { https://www.nbp.pl/en/aktualnosci/ } \\
\text { 2020/mpc 2020 04 08.pdf }\end{array}$ \\
\hline Poland & $28 / 05 / 2020$ & $\begin{array}{l}\text { changing the long-term liquidity structure in the } \\
\text { banking sector, ensuring the liquidity in secondary } \\
\text { markets for the purchased securities and enhancing } \\
\text { the impact of the NBP interest rate cuts on the } \\
\text { economy, i.e. strengthening the monetary policy } \\
\text { transmission }\end{array}$ & & & & Y & & & & & & Y & & & & $\begin{array}{l}\text { https://www.nbp.pl/en/aktualnosci/ } \\
\text { 2020/mpc 2020 05 28.pdf }\end{array}$ \\
\hline Poland & $14 / 07 / 2020$ & $\begin{array}{l}\text { changing the long-term liquidity structure in the } \\
\text { banking sector, ensuring the liquidity in secondary } \\
\text { markets for the purchased securities and enhancing } \\
\text { the impact of the NBP interest rate cuts on the } \\
\text { economy, i.e. strengthening the monetary policy } \\
\text { transmission }\end{array}$ & & & & $\mathrm{Y}$ & & & & & & $\mathrm{Y}$ & & & & $\begin{array}{l}\text { https://www.nbp.pl/en/aktualnosci/ } \\
\text { 2020/mpc_2020_07_14.pdf }\end{array}$ \\
\hline
\end{tabular}




\begin{tabular}{|c|c|c|c|c|c|c|c|c|c|c|c|c|c|c|c|c|}
\hline \multicolumn{17}{|c|}{ Annex II. Details on Taxonomy of Objectives (continued) } \\
\hline Country & $\begin{array}{l}\text { Date Press } \\
\text { Release }\end{array}$ & Objective & 1 & 2 & $\begin{array}{l}3 \\
\mathrm{~A}\end{array}$ & $\begin{array}{l}3 \\
\mathrm{~B}\end{array}$ & $\begin{array}{l}3 \\
\mathrm{C}\end{array}$ & $\begin{array}{l}3 \\
\mathrm{D}\end{array}$ & $\begin{array}{l}3 \\
\mathrm{E}\end{array}$ & $\begin{array}{l}3 \\
F\end{array}$ & $\begin{array}{l}3 \\
\mathrm{G}\end{array}$ & $\begin{array}{l}3 \\
\mathrm{H}\end{array}$ & $\begin{array}{l}4 \\
\mathrm{~A}\end{array}$ & $\begin{array}{l}4 \\
\mathrm{~B}\end{array}$ & 5 & \\
\hline Romania & $20 / 03 / 2020$ & $\begin{array}{l}\text { with a view to consolidating structural liquidity in } \\
\text { the banking system that should contribute to the } \\
\text { smooth financing of real economy and the public } \\
\text { sector }\end{array}$ & & & & & $\mathrm{Y}$ & & & $\mathrm{Y}$ & & $\mathrm{Y}$ & & & & $\begin{array}{l}\text { https://www.bnr.ro/page.aspx?prid } \\
=17617\end{array}$ \\
\hline Romania & $29 / 05 / 2020$ & $\begin{array}{l}\text { Given the liquidity shortfall on the money market } \\
\text { keeping financial market stability }\end{array}$ & & & & & & & & $\mathrm{Y}$ & & $\mathrm{Y}$ & & & & $\begin{array}{l}\text { https://www.bnr.ro/page.aspx?prid } \\
=17856\end{array}$ \\
\hline Romania & $05 / 08 / 2020$ & Given the liquidity shortfall on the money market & & & & & & & & & & $\mathrm{Y}$ & & & & $\begin{array}{l}\text { https://www.bnr.ro/page.aspx?prid } \\
=18196\end{array}$ \\
\hline Rwanda & $18 / 03 / 2020$ & $\begin{array}{l}\text { to come up with measures to mitigate the } \\
\text { economic impact of the pandemic }\end{array}$ & & Y & & & & & & & & & & & & $\begin{array}{l}\text { https://www.bnr.rw/news- } \\
\text { publications/news/news-press- } \\
\text { release/?tx_bnrdocumentmanager_f } \\
\text { rontend } \% 5 \mathrm{~B} \% 40 \text { widget_0\%5D\%5 } \\
\text { BcurrentPage } \% 5 \mathrm{D}=2 \& \mathrm{c}=\mathrm{Hash}=500 \\
\text { d137651682102ac8fbea92fa87d75 }\end{array}$ \\
\hline $\begin{array}{l}\text { South } \\
\text { Africa }\end{array}$ & $25 / 03 / 2020$ & $\begin{array}{l}\text { As a further measure to add liquidity to the } \\
\text { market ; providing liquidity and promoting the } \\
\text { smooth functioning of domestic financial markets ; } \\
\text { enhance its Monetary Policy Portfolio (MPP) [used } \\
\text { for] managing money market liquidity } \\
\text { [Complementary information in Q\&A:] ensure that } \\
\text { its monetary policy decisions are effective and that } \\
\text { these decisions have an impact, even if it is an } \\
\text { indirect effect, on the cost of borrowing in the } \\
\text { economy. reduce excessive volatility in the price } \\
\text { of government bonds Orderly functioning in the } \\
\text { market for government bonds }\end{array}$ & & & & Y & & Y & Y & Y & Y & Y & & & & $\begin{array}{l}\frac{\text { https: } / / \text { www.resbank.co.za/Lists/Ne }}{\text { ws } \% 20 \text { and } \% 20 \text { Publications/Attach }} \\
\text { ments/9805/Further\%20amendmen } \\
\text { ts } \% 20 \text { to } \% 20 \text { the } \% 20 \text { money } \% 20 \text { mar } \\
\text { ket } \% 20 \text { liquidity } \% 20 \text { management } \% \\
\text { 20strategy } \% 20 \text { of } \% 20 \text { the } \% 20 \text { SARB } \\
\text { pdf }\end{array}$ \\
\hline Sweden & $16 / 03 / 2020$ & $\begin{array}{l}\text { to facilitate credit supply; to provide support to } \\
\text { economic development }\end{array}$ & & & & & $\mathrm{Y}$ & & & & & & & & & $\begin{array}{l}\text { https://www.riksbank.se/en- } \\
\text { gb/press-and-published/notices- } \\
\text { and-press-releases/press- } \\
\text { releases/2020/the-riksbank-to- } \\
\text { increase-asset-purchases-and-take- } \\
\text { measures-to-facilitate-credit- } \\
\text { supply/ }\end{array}$ \\
\hline
\end{tabular}




\begin{tabular}{|c|c|c|c|c|c|c|c|c|c|c|c|c|c|c|c|c|}
\hline \multicolumn{17}{|c|}{ Annex II. Details on Taxonomy of Objectives (continued) } \\
\hline Country & $\begin{array}{l}\text { Date Press } \\
\text { Release }\end{array}$ & Objective & 1 & 2 & $\begin{array}{l}3 \\
\mathrm{~A}\end{array}$ & $\begin{array}{l}3 \\
\mathrm{~B}\end{array}$ & $\begin{array}{l}3 \\
\mathrm{C}\end{array}$ & $\begin{array}{l}3 \\
\mathrm{D}\end{array}$ & $\begin{array}{l}3 \\
\mathrm{E}\end{array}$ & $\begin{array}{l}3 \\
F\end{array}$ & $\begin{array}{l}3 \\
\mathrm{G}\end{array}$ & $\begin{array}{l}3 \\
\mathrm{H}\end{array}$ & $\begin{array}{l}4 \\
\mathrm{~A}\end{array}$ & $\begin{array}{l}4 \\
\mathrm{~B}\end{array}$ & 5 & \\
\hline Sweden & $16 / 03 / 2020$ & $\begin{array}{l}\text { to facilitate credit supply; to provide support to } \\
\text { economic development }\end{array}$ & & & & & $\mathrm{Y}$ & & & & & & & & & $\begin{array}{l}\text { https://www.riksbank.se/en- } \\
\text { gb/press-and-published/notices- } \\
\text { and-press-releases/press- } \\
\text { releases/2020/the-riksbank-to- } \\
\text { increase-asset-purchases-and-take- } \\
\text { measures-to-facilitate-credit- } \\
\text { supply/ }\end{array}$ \\
\hline Sweden & $19 / 03 / 2020$ & $\begin{array}{l}\text { supply the necessary liquidity even between the } \\
\text { ordinary monetary policy meetings [See annex D:] } \\
\text { To keep monetary policy expansionary, provide } \\
\text { support to the economy and bolster credit supply } \\
\text { broadly in the Swedish economy }\end{array}$ & & & & & $\mathrm{Y}$ & & & & & $\mathrm{Y}$ & $\mathrm{Y}$ & & & $\begin{array}{l}\text { https://www.riksbank.se/en- } \\
\text { gb/press-and-published/notices- } \\
\text { and-press-releases/press- } \\
\text { releases/2020/additional-measures- } \\
\text { to-mitigate-the-effects-of-the- } \\
\text { corona-pandemic-on-the-swedish- } \\
\text { economy/ }\end{array}$ \\
\hline Sweden & $21 / 04 / 2020$ & $\begin{array}{l}\text { making monetary policy more expansionary. To } \\
\text { mitigate the effects of the corona pandemic on the } \\
\text { Swedish economy aimed at keeping interest rates } \\
\text { in general at a low level and contributing to an } \\
\text { efficient supply of credit }\end{array}$ & & $\mathrm{Y}$ & & & $\mathrm{Y}$ & $\mathrm{Y}$ & & & & & $\mathrm{Y}$ & & & $\begin{array}{l}\mathrm{https} / / \text { www.riksbank.se/en- } \\
\mathrm{gb} / \text { monetary-policy/monetary- } \\
\text { policy-instruments/purchases-of- } \\
\text { government-bonds/ }\end{array}$ \\
\hline Thailand & $17 / 03 / 2020$ & $\begin{array}{l}\text { liquidity has become tight in bond and US dollar } \\
\text { exchange markets }\end{array}$ & & & & & & & & & & $\mathrm{Y}$ & & & & $\begin{array}{l}\text { https://www.nationthailand.com/bu } \\
\text { siness/30384264 }\end{array}$ \\
\hline Thailand & $22 / 03 / 2020$ & $\begin{array}{l}\text { to lower the volatility of the government bond } \\
\text { yield and ensure the normal functioning of the } \\
\text { government bond market. to ensure that the } \\
\text { government bond market continues to function } \\
\text { normally to provide liquidity and help the normal } \\
\text { functioning of the financial market and help build } \\
\text { investors' confidence }\end{array}$ & & & Y & & & & Y & & Y & $\mathrm{Y}$ & & & & $\begin{array}{l}\text { https://www.bot.or.th/English/Abo } \\
\text { utBOT/Activities/Pages/Joint_2203 } \\
\text { 2020.aspx }\end{array}$ \\
\hline Thailand & $22 / 03 / 2020$ & $\begin{array}{l}\text { to invest in high-quality, newly issued bonds by } \\
\text { corporates that cannot fully rollover maturing } \\
\text { corporate bonds to provide liquidity and help the } \\
\text { normal functioning of the financial market and } \\
\text { help build investors' confidence }\end{array}$ & & & Y & & & & & & Y & Y & & & & $\begin{array}{l}\text { https://www.bot.or.th/English/Abo } \\
\text { utBOT/Activities/Pages/Joint_2203 } \\
\text { 2020.aspx }\end{array}$ \\
\hline
\end{tabular}




\begin{tabular}{|c|c|c|c|c|c|c|c|c|c|c|c|c|c|c|c|c|}
\hline \multicolumn{17}{|c|}{ Annex II. Details on Taxonomy of Objectives (concluded) } \\
\hline Country & $\begin{array}{l}\text { Date Press } \\
\text { Release }\end{array}$ & Objective & 1 & 2 & $\begin{array}{l}3 \\
\mathrm{~A}\end{array}$ & $\begin{array}{l}3 \\
\mathrm{~B}\end{array}$ & $\begin{array}{l}3 \\
\mathrm{C}\end{array}$ & $\begin{array}{l}3 \\
\mathrm{D}\end{array}$ & $\begin{array}{l}3 \\
\mathrm{E}\end{array}$ & $\begin{array}{l}3 \\
\mathrm{~F}\end{array}$ & $\begin{array}{l}3 \\
\mathrm{G}\end{array}$ & $\begin{array}{l}3 \\
\mathrm{H}\end{array}$ & $\begin{array}{l}4 \\
\mathrm{~A}\end{array}$ & $\begin{array}{l}4 \\
\mathrm{~B}\end{array}$ & 5 & \\
\hline Thailand & $07 / 04 / 2020$ & $\begin{array}{l}\text { to stabilize the corporate bond market by providing } \\
\text { liquidity backstop to ensure its continued } \\
\text { functioning to provide bridge financing to high- } \\
\text { quality firms with bonds maturing during 2020- } \\
\text { 2021, at higher-than-market 'penalty' rates }\end{array}$ & & & & & Y & & & Y & & $\mathrm{Y}$ & & & & $\begin{array}{l}\text { https://www.bot.or.th/English/Press } \\
\text { andSpeeches/Press/2020/Pages/n20 } \\
\text { 63.aspx }\end{array}$ \\
\hline Turkey & $31 / 03 / 2020$ & $\begin{array}{l}\text { enhance the effectiveness of the monetary } \\
\text { transmission mechanism via increasing the market } \\
\text { depth, enabling sound asset pricing and providing } \\
\text { banks with flexibility in liquidity management }\end{array}$ & & & & & & Y & & & Y & Y & & & & $\begin{array}{l}\text { https://www.tcmb.gov.tr/wps/wcm/ } \\
\text { connect/en/tcmb+en/main+menu/a } \\
\text { nnouncements/press+releases/2020 } \\
\text { /ano2020-21 }\end{array}$ \\
\hline Turkey & $17 / 04 / 2020$ & $\begin{array}{l}\text { to maintain market depth, strengthen the monetary } \\
\text { policy transmission mechanism and support the } \\
\text { Primary Dealership system }\end{array}$ & & & & $\mathrm{Y}$ & & & & Y & & & & & & $\begin{array}{l}\text { https://www.tcmb.gov.tr/wps/wcm/ } \\
\text { connect/EN/TCMB+EN/Main+Me } \\
\text { nu/Announcements/Press+Releases } \\
\text { /2020/ANO2020-22 }\end{array}$ \\
\hline Uganda & $06 / 04 / 2020$ & $\begin{array}{l}\text { to ease [Microfinance Deposit taking Institutions } \\
\text { (MDIs) and Credit Institutions (CIs)] liquidity } \\
\text { distress whenever it arises. }\end{array}$ & & & Y & & & & & & & & & & & $\begin{array}{l}\text { https://www.bou.or.ug/bou/bouweb } \\
\text { site/bouwebsitecontent/MonetaryP } \\
\text { olicy/Monetary_Policy_Statements } \\
\text { /MPS-April-2020-FINAL.pdf }\end{array}$ \\
\hline
\end{tabular}




\section{Annex III. Econometric Results}

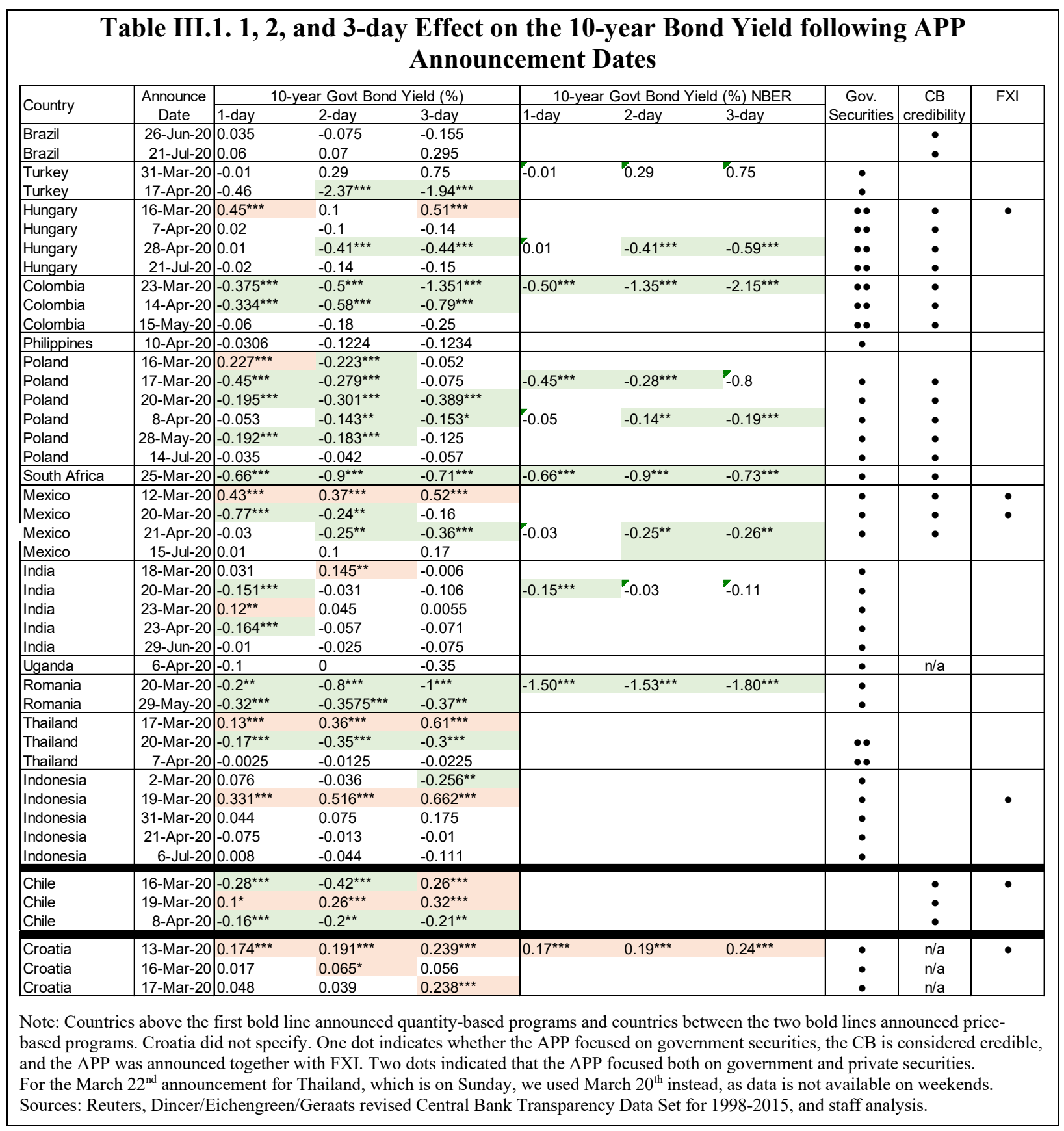




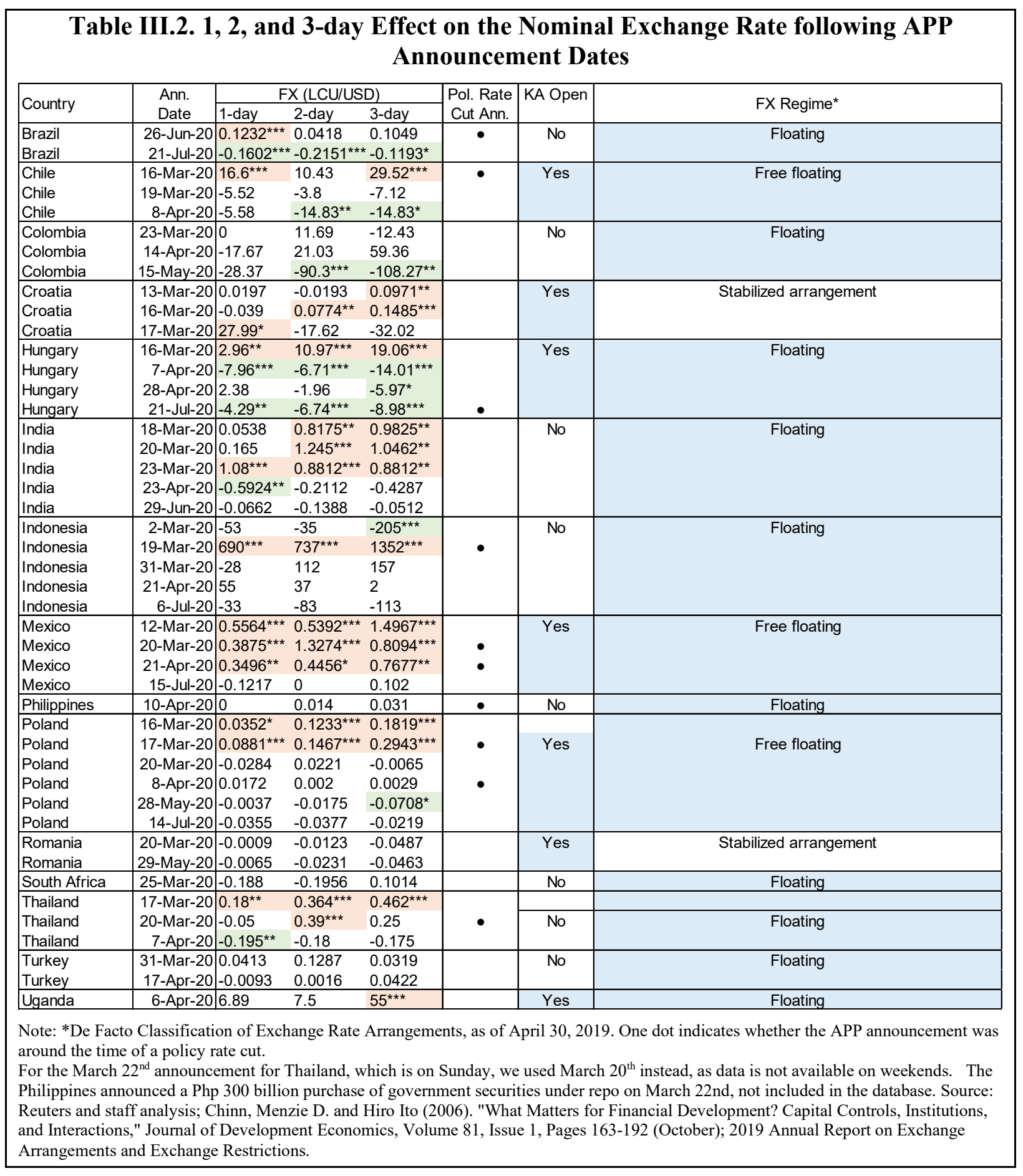


Table III.3. 1, 2, and 3-day Effect on the Nominal Exchange Rate following Policy Rate Cut Announcement Dates

\begin{tabular}{|c|c|c|c|c|}
\hline \multirow{2}{*}{ Country } & \multirow{2}{*}{$\begin{array}{l}\text { Pol. Rate } \\
\text { Cut Date }\end{array}$} & \multicolumn{3}{|c|}{$\mathrm{FX}(\mathrm{LCU} / \mathrm{USD})$} \\
\hline & & 1-day & 2-day & 3-day \\
\hline Brazil & 4-Feb-20 & 0.0077 & -0.0057 & 0.0356 \\
\hline Brazil & 17-Mar-20 & 0.0088 & $0.1085^{* *}$ & $0.0957^{*}$ \\
\hline Brazil & 5-May-20 & 0.0347 & $0.1738^{* * *}$ & $0.292^{* * *}$ \\
\hline Brazil & 16-Jun-20 & $0.0881^{* *}$ & 0.072 & $0.2217^{* * *}$ \\
\hline Chile & 16-Mar-20 & $16.6^{\star * *}$ & 10.43 & $29.52^{* * *}$ \\
\hline Chile & 31-Mar-20 & 2.98 & 9.15 & 6.83 \\
\hline Colombia & 30-Jun-20 & 7.58 & -34.62 & $-107.37^{* *}$ \\
\hline Hungary & 23-Jun-20 & 0.56 & $4.31^{*}$ & $7.26^{* *}$ \\
\hline Hungary & 21-Jul-20 & $-4.29 * *$ & $-6.74^{* * *}$ & $-8.98^{* * *}$ \\
\hline India & 26-Mar-20 & $-0.9212^{* * *}$ & * $-1.1562^{* * *}$ & ${ }^{\star}-.6599^{*}$ \\
\hline India & 21-May-20 & -0.1825 & 0.1663 & 0.1663 \\
\hline Indonesia & 19-Feb-20 & 1 & 56 & 66 \\
\hline Indonesia & 18-Mar-20 & 50 & $740^{* * *}$ & $787^{* \star *}$ \\
\hline Indonesia & 17-Jun-20 & -7 & -12 & 10 \\
\hline Indonesia & 15-Jul-20 & $138^{* *}$ & $175^{*}$ & $253^{* *}$ \\
\hline Mexico & 12-Feb-20 & -0.0366 & -0.058 & -0.1158 \\
\hline Mexico & 19-Mar-20 & $0.3272^{* *}$ & $0.7147^{* * *}$ & $1.6546^{\star * *}$ \\
\hline Mexico & 20-Apr-20 & $0.3478^{* *}$ & $0.6974^{* * *}$ & $0.7934^{* * *}$ \\
\hline Mexico & 13-May-20 & -0.1833 & $-0.5033^{* *}$ & -0.4137 \\
\hline Mexico & 24-Jun-20 & $0.3695^{* *}$ & 0.2342 & $0.6263^{* *}$ \\
\hline Philippines & 6-Feb-20 & -0.14 & -0.152 & -0.13 \\
\hline Philippines & 19-Mar-20 & -0.03 & -0.25 & 0.185 \\
\hline Philippines & 16-Apr-20 & 0.171 & 0.298 & 0.168 \\
\hline Philippines & 25-Jun-20 & 0.032 & -0.05 & -0.118 \\
\hline Poland & 17-Mar-20 & $0.0881^{* * *}$ & $0.1467^{* * *}$ & $0.2943^{\text {*** }}$ \\
\hline Poland & 8-Apr-20 & 0.0172 & 0.002 & 0.0029 \\
\hline Poland & 28-May-20 & -0.0037 & -0.0175 & $-0.0708^{*}$ \\
\hline Romania & \begin{tabular}{|l|}
$1-J u n-20$ \\
\end{tabular} & -0.0166 & -0.0398 & $-0.0665^{\star *}$ \\
\hline South Africa & 15-Jan-20 & -0.0134 & 0.0121 & 0.0671 \\
\hline South Africa & 19-Mar-20 & $0.3715^{\star * *}$ & $0.5145^{* * *}$ & $0.7415^{\star * *}$ \\
\hline South Africa & 13-Apr-20 & 0.168 & $0.3615^{*}$ & $0.736^{* * *}$ \\
\hline South Africa & 21-May-20 & $-0.329^{* *}$ & -0.2993 & -0.2781 \\
\hline South Africa & 23-Jul-20 & 0.1807 & 0.1729 & -0.0596 \\
\hline Thailand & 4-Feb-20 & $-0.164^{*}$ & -0.147 & -0.014 \\
\hline Thailand & 20-Mar-20 & -0.05 & $0.39^{* * *}$ & 0.25 \\
\hline Thailand & 19-May-20 & $-0.149^{*}$ & -0.212 & -0.204 \\
\hline Turkey & 16-Jan-20 & -0.0156 & 0.0111 & 0.0405 \\
\hline Turkey & 19-Feb-20 & 0.0193 & 0.0324 & 0.0314 \\
\hline Turkey & 17-Mar-20 & -0.0337 & 0.0508 & 0.1123 \\
\hline Turkey & 22-Apr-20 & 0.0012 & -0.0347 & -0.0082 \\
\hline Turkey & 21-May-20 & 0.004 & 0.0231 & 0.0213 \\
\hline Uganda & 5-Jun-20 & $-30.26^{* * *}$ & -17.5 & $-34.9^{\star *}$ \\
\hline
\end{tabular}

Sources: Reuters and staff analysis. 
Table III.4. 1, 2, and 3-day Effect on the EMBI Spread following APP Announcement Dates

\begin{tabular}{|c|c|c|c|c|}
\hline \multirow{2}{*}{ Country } & \multirow{2}{*}{$\begin{array}{c}\text { Announce } \\
\text { Date }\end{array}$} & \multicolumn{3}{|c|}{ EMBI (bp) } \\
\hline & & 1-day & 2-day & 3-day \\
\hline Brazil & 26-Jun-20 & 6 & 6 & 0 \\
\hline Brazil & 21-Jul-20 & -9 & -12 & -3 \\
\hline Turkey & 31-Mar-20 & -4 & $40^{* *}$ & $57^{* \star *}$ \\
\hline Turkey & 17-Apr-20 & -6 & $-35^{\star}$ & -29 \\
\hline Hungary & 16-Mar-20 & $20^{* \star *}$ & -1 & $15^{* *}$ \\
\hline Hungary & 7-Apr-20 & -7 & 6 & -7 \\
\hline Hungary & 28-Apr-20 & 3 & -1 & -3 \\
\hline Hungary & 21-Jul-20 & -2 & -5 & -6 \\
\hline Colombia & 23-Mar-20 & $23^{* \star *}$ & -8 & $-85^{\star \star *}$ \\
\hline Colombia & 14-Apr-20 & -9 & $19^{*}$ & $34^{* *}$ \\
\hline Colombia & 15-May-20 & -7 & $-30^{* * *}$ & $-33^{* *}$ \\
\hline Philippines & 10-Apr-20 & 0 & -4 & $-16^{*}$ \\
\hline Poland & 16-Mar-20 & $23^{* * *}$ & $8^{*}$ & 6 \\
\hline Poland & 17-Mar-20 & $-15^{\star \star \star}$ & $-17^{* \star *}$ & -9 \\
\hline Poland & 20-Mar-20 & $12^{* \star \star}$ & $16^{* * *}$ & $12^{\star *}$ \\
\hline Poland & 8-Apr-20 & -2 & 0 & 0 \\
\hline Poland & 28-May-20 & $-7^{*}$ & -8 & $-16^{* * *}$ \\
\hline Poland & 14-Jul-20 & 2 & -3 & -2 \\
\hline South Africa & 25-Mar-20 & $-66^{\star \star \star}$ & $-93^{* * *}$ & $-64^{* * *}$ \\
\hline Mexico & 12-Mar-20 & $53^{* * *}$ & 4 & $86^{\star \star *}$ \\
\hline Mexico & 20-Mar-20 & $-39 * * *$ & 8 & $-36^{* * *}$ \\
\hline Mexico & 21-Apr-20 & $18^{*}$ & 11 & 26 \\
\hline Mexico & 15-Jul-20 & -12 & -10 & -18 \\
\hline India & 18-Mar-20 & $44^{\star \star \star}$ & $80^{\star * *}$ & $120^{* * *}$ \\
\hline India & 20-Mar-20 & $40^{* * *}$ & $56^{* * *}$ & $52^{* * *}$ \\
\hline India & 23-Mar-20 & $16^{* * *}$ & $12^{*}$ & $44^{* * *}$ \\
\hline India & 23-Apr-20 & 0 & -1 & 4 \\
\hline India & 29-Jun-20 & 5 & 12 & 10 \\
\hline Uganda & 6-Apr-20 & $\mathrm{n} / \mathrm{a}$ & $\mathrm{n} / \mathrm{a}$ & $\mathrm{n} / \mathrm{a}$ \\
\hline Romania & 20-Mar-20 & $-12.41^{* *}$ & $22.61^{* * *}$ & 11.8 \\
\hline Romania & 29-May-20 & -5.55 & $-14.8^{*}$ & $-24.79^{* *}$ \\
\hline Thailand & 17-Mar-20 & $\mathrm{n} / \mathrm{a}$ & $\mathrm{n} / \mathrm{a}$ & $\mathrm{n} / \mathrm{a}$ \\
\hline Thailand & 20-Mar-20 & $\mathrm{n} / \mathrm{a}$ & $\mathrm{n} / \mathrm{a}$ & $\mathrm{n} / \mathrm{a}$ \\
\hline Thailand & 7-Apr-20 & $\mathrm{n} / \mathrm{a}$ & $\mathrm{n} / \mathrm{a}$ & $\mathrm{n} / \mathrm{a}$ \\
\hline Indonesia & 2-Mar-20 & 0 & 4 & -7 \\
\hline Indonesia & 19-Mar-20 & $51^{* \star *}$ & $55^{\star \star *}$ & $97^{\star \star \star}$ \\
\hline Indonesia & 31-Mar-20 & -9 & -1 & 6 \\
\hline Indonesia & 21-Apr-20 & 8 & 10 & 6 \\
\hline Indonesia & 6-Jul-20 & -5 & -1 & -2 \\
\hline Chile & 16-Mar-20 & $44^{* * *}$ & $42^{* \star *}$ & $82^{* * *}$ \\
\hline Chile & 19-Mar-20 & $13^{* * *}$ & 8 & $22^{* * *}$ \\
\hline Chile & 8-Apr-20 & -3 & $-11^{*}$ & -11 \\
\hline Croatia & 13-Mar-20 & $15^{\star \star \star}$ & $56^{* \star *}$ & $67^{* \star *}$ \\
\hline Croatia & 16-Mar-20 & $41^{* * *}$ & $52^{* * *}$ & $73^{* * *}$ \\
\hline Croatia & 17-Mar-20 & $11^{* *}$ & $32^{* * *}$ & $75^{\star * *}$ \\
\hline
\end{tabular}

Note: For the March $22^{\text {nd }}$ announcement for Thailand, which is on Sunday, we used March $20^{\text {th }}$ instead, as data is not available on weekends. The Philippines announced a Php 300 billion purchase of government securities under repo on March 22nd, not included in the database.

Sources: Reuters and staff analysis. 


\section{Annex IV. Event Study with Controls and a Panel Regression}

We enhance the event study methodology discussed in Section IV to control for global factors (e.g., periods of heightened volatility), and other factors (e.g., other CB policies, pandemic-related shocks) that may affect the variables of interest. ${ }^{51} \mathrm{We}$ use country specific OLS regressions, with the variables of interest as the dependent variable. The right-hand side includes a dummy capturing the APP announcement dates as well as control variables such as the VIX (to gauge for financial market risk aversion and a general proxy for financial turmoil, economic risk and uncertainty), the domestic central bank policy rate change, the Fed's policy rate change, as well as the Oxford index ${ }^{52}$ and the Google mobility index ${ }^{53}$ in order to control for effects related to the covid-19 pandemic. The following regression is estimated for every country using daily data from January 1, 2020 until the end of August:

$$
\Delta Y_{i t}=\alpha+\beta_{1} A N N_{i t}+\beta_{2} V_{I X}+\beta_{3} \Delta I_{i t}+\beta_{4} \Delta F E D_{t}+\beta_{5} \text { Oxford }_{i t}+\beta_{6} \text { Google }_{i t}+\varepsilon_{t}
$$

Where Ys are the variables of interest used in the previous event study, ANN is the dummy variable capturing the days of APP announcements, I is the domestic policy rate change, FED is the Fed's policy rate change, VIX is the volatility index, Oxford is the government response to COVID-19 tracked by the University of Oxford, and Google is the Google mobility index.

The regression results for every country are presented in the table below, showing the coefficients on the announcement dummy variable only from every regression. They confirm that even when other factors are considered, the APP announcements have a statistically significant and negative effect on the bond yields and little effects on the exchange rate as well as the remaining dependent variables. This is probably because some announcements have a positive effect on the exchange rate while other have a negative one. Furthermore, the control variables such as the VIX and the FED's policy rate change often had statistically significant coefficients, positive and negative, respectively in the regressions with the exchange rate. These effects of the VIX index and the FED policy rate change likely washes out the significant effect on the exchange rate. Using a dummy variable with the implementation dates did not yield any statistically significant results for the countries where data is available. However, these results should be taken as an illustration only and interpreted with caution as there is little variability in the data.

\footnotetext{
${ }^{51}$ Rai and Suchanek (2014); Falagiarda, McQuade, and Tirpak (2015); and IMF (2016); use a similar methodology.

52 The Oxford COVID-19 Government Response Tracker (OxCGRT) systematically collects information on several different common policy responses that governments have taken to respond to the pandemic on 17 indicators such as school closures and travel restrictions.

${ }^{53}$ Using mobility trends for places of work.
} 
To further check whether the main findings of the event study methodology without controls regarding the effects of UMP hold, we use a panel regression as well. We run a panel regression with fixed effects, where the specifications of the dependent and independent variables are the same as the ones with the country-level regressions. ${ }^{54}$

The results, using the full sample in our database including both EMDEs and AEs, indicates that the APP announcements had a statistically significant and negative effect on the bond yield across maturities. Restricting the sample to EMDEs only confirms these and illustrates the stronger effect of APP announcements. In addition, the effect on the exchange rate is not statistically significant ${ }^{55}$, similar to the findings of Chapter 2 of the October GFSR. Finally, including a dummy variable for the implementation days did not yield any statistically significant results, which is most likely due to the limitation of the data.

Next, we explore whether there are any patterns in the effectiveness of APP announcements. To do so, we interact the announcement dummy variable with a number of structural characteristics. In particular, we explore the role of central bank credibility (measured by the variability of long-term inflation forecasts), central bank transparency, the share of nonresidential investment, the monetary regime (inflation targeting or other regimes), the announced size of the APP, and the exchange rate regime (floating or not). We use the specification of the panel regressions above.

The coefficients of the announcement dummy interacted with the country structural characteristics are reported in Table IV.4 below. We find that APP announcement made by credible central banks are more effective (in terms of their impact on bond yields). We do not find evidence of the role of central bank transparency, the non-residential investment share, or the monetary regime and the exchange rate regime on the effectiveness of the APP. However, we ascribe the latter to the little heterogeneity in the sample, rather than a conclusive statement on the role of the exchange rate regime. Specifically, most of the countries in the sample have a floating exchange rate regime, with the exception of Croatia, Egypt, and Indonesia. Similarly, most countries in the sample follow an inflation targeting regime, with the exception of Croatia and Egypt.

Interestingly, we find that larger programs, as measured by the announced size as a share of GDP, are associated with smaller effects on the government 10-year bond markets. This can be interpreted as an indication that markets may not yet be reacting fully, or know how to absorb the information, of these new unconventional policies. It could also be attributed to the prevailing market uncertainty and strong risk aversion arising from the pandemic.

Furthermore, announcements of the Chile price-based program targeting bank bonds had the

\footnotetext{
${ }^{54}$ In a separate specification we also included lagged values of the dependent variable. As this did not yield results that are materially different, we do not discuss them here.

${ }^{55}$ We exclude Indonesia both from the full as well as the EMDE sample as it is a large outlier.
} 
opposite effect on sovereign bond markets than announcements of quantity-based programs. We also find that programs with multiple announcements as well as those announced in countries with low monetary space are associated with smaller effects on the government 10year bond markets. Overall, conclusions on the role of the institutional framework and the APP characteristics are robust to the inclusion of AEs in the regressions as well as to the restrictions of the sample to the first announcements for each program. ${ }^{56}$

When the sample is restricted to the first announcement of each program (Table IV.5), in order to investigate the surprise effect, we find broadly similar results. One notable result is that when the first announcement is considered only, central bank transparency matters as well for the effectiveness of APPs. Finally, trying to distinguish between the effectiveness of APPs between EMDEs and the small AEs in our sample, we find a more significant impact for EMDEs (Table IV.6). However, the results related to the implementation dates may be biased due to the very small sample size for EMDEs.

\begin{tabular}{|c|c|c|c|c|c|c|c|c|c|c|}
\hline \multicolumn{11}{|c|}{ Table IV.1. Regression Coefficient on the Announcement Dummy Variable } \\
\hline Country & $10 Y \mathrm{BY}$ & $5 Y \mathrm{BY}$ & $2 Y B Y$ & $6 \mathrm{MBY}$ & EMBI & Equities & FX & KA Open & FX regime & CB credibility \\
\hline Brazil & 0.0384 & 0.0928 & -0.0314 & 0.0261 & 7.129 & $-2,581$ & 0.125 & no & floating & yes \\
\hline Chile & -0.0580 & 0.0809 & 0.0373 & & 6.761 & 76.16 & -7.294 & yes & free floating & yes \\
\hline Colombia & -0.173 & $-0.248^{*}$ & $-0.248^{*}$ & $-0.248^{*}$ & 5.936 & & -11.21 & no & floating & yes \\
\hline Croatia & $0.0691^{* * *}$ & $0.0757^{* \star}$ & & & 4.280 & $86.91^{* * *}$ & 0.0285 & yes & stabilized arrangement & no \\
\hline Hungary & 0.0471 & 0.0499 & & 0.0189 & 1.954 & 9.058 & $-3.106^{*}$ & yes & floating & yes \\
\hline India & $-0.0583^{* *}$ & -0.0646 & -0.0340 & -0.0221 & $11.29^{* *}$ & -155.1 & 0.00607 & no & floating & no \\
\hline Indonesia & 0.0355 & 0.0484 & & 0.00723 & 3.901 & -17.93 & 49.03 & no & floating & no \\
\hline Mexico & -0.0281 & -0.0135 & & -0.0572 & -4.336 & -354.1 & 0.181 & yes & free floating & yes \\
\hline Philippines & 0.00296 & 0.00800 & 0.0198 & 0.0186 & 3.873 & -30.85 & 0.0168 & no & floating & no \\
\hline Poland & $-0.172^{\star \star *}$ & $-0.138^{\star \star \star}$ & $-0.129^{* \star *}$ & & -1.273 & 417.3 & -0.00103 & yes & free floating & yes \\
\hline Romania & $-0.308^{* * *}$ & -0.121 & -0.0765 & -7.76 & -14.28 & -6.324 & -0.00908 & yes & stabilized arrangement & no \\
\hline South Africa & $-0.841^{\star * *}$ & $-0.788^{* \star *}$ & $-0.355^{\star \star}$ & & $-89.45^{* * *}$ & $2,514^{* *}$ & $-0.363^{\star}$ & no & floating & yes \\
\hline Thailand & $-0.0685^{*}$ & -0.0383 & $-0.0771^{* * *}$ & & -1.782 & $65.60^{\star * *}$ & -0.0721 & no & floating & no \\
\hline Turkey & -0.244 & -0.155 & -0.0617 & 0.0653 & -4.720 & 15.04 & 0.00761 & no & floating & no \\
\hline Uganda & 0.364 & 0.00505 & -0.191 & $1.149^{*}$ & & & -2.507 & yes & floating & no \\
\hline Panel (AEs+EMDEs) & $-0.0862^{* * *}$ & ${ }^{*}-0.0640^{* * *}$ & $-0.0424^{*}$ & -0.00997 & -2.327 & 120.1 & -1.992 & & & \\
\hline Panel (EMDEs) & $-0.135^{\star \star *}$ & $-0.0921^{\star \star *}$ & $-0.0732^{* *}$ & -0.0216 & -2.327 & 75.70 & -2.966 & & & \\
\hline Credible CB & $-0.146^{\star \star *}$ & $-0.125^{\star \star \star}$ & $-0.154^{* \star *}$ & $-0.0473^{*}$ & -6.268 & 53.52 & -4.042 & & & \\
\hline Non Credible CB & $-0.0925^{* * *}$ & ${ }^{*}-0.0640^{* *}$ & -0.0533 & -0.0343 & 3.889 & -79.77 & -0.556 & & & \\
\hline $\begin{array}{l}\text { Transparent CB } \\
\end{array}$ & $-0.160^{* \star *}$ & $-0.110^{* * *}$ & $-0.0926^{* *}$ & 0.000359 & -2.116 & $345.7^{* *}$ & $-1.498^{* *}$ & & & \\
\hline Non Transparent CB & $-0.102^{* *}$ & -0.0613 & -0.0267 & -0.0562 & -2.818 & -236.0 & -5.016 & & & \\
\hline
\end{tabular}

\footnotetext{
${ }^{56}$ Robustness checks are not shown in full and are available upon request.
} 


\begin{tabular}{|c|c|c|c|c|c|c|c|}
\hline \multicolumn{8}{|c|}{ Table IV.2. Panel Regression Results, EMDE Sample } \\
\hline VARIABLES & 10Y BY & $5 Y \mathrm{BY}$ & $2 Y \mathrm{BY}$ & $6 \mathrm{M} \mathrm{BY}$ & EMBI & Equities & $F X$ \\
\hline Announce & $\begin{array}{l}-0.135^{\star \star *} \\
(0.0284)\end{array}$ & $\begin{array}{l}-0.0921^{* \star *} \\
(0.0302)\end{array}$ & $\begin{array}{l}-0.0732^{\star *} \\
(0.0357)\end{array}$ & $\begin{array}{l}-0.0216 \\
(0.0497)\end{array}$ & $\begin{array}{l}-2.327 \\
(3.072)\end{array}$ & $\begin{array}{l}75.70 \\
(176.5)\end{array}$ & $\begin{array}{l}-2.966 \\
(2.039)\end{array}$ \\
\hline VIX & $\begin{array}{l}0.00179^{* * *} \\
(0.000322)\end{array}$ & $\begin{array}{l}0.00148^{* * *} \\
(0.000343)\end{array}$ & $\begin{array}{l}0.000602 \\
(0.000380)\end{array}$ & $\begin{array}{l}6.30 \mathrm{e}-06 \\
(0.000523)\end{array}$ & $\begin{array}{l}0.237^{* * *} \\
(0.0370)\end{array}$ & $\begin{array}{l}-5.868^{* * *} \\
(2.087)\end{array}$ & $\begin{array}{l}0.0736^{* * *} \\
(0.0232)\end{array}$ \\
\hline$\Delta$ dom policy rate & $\begin{array}{l}0.0359 \\
(0.0490)\end{array}$ & $\begin{array}{l}0.141^{* * *} \\
(0.0521)\end{array}$ & $\begin{array}{l}0.0739 \\
(0.0523)\end{array}$ & $\begin{array}{l}0.139^{*} \\
(0.0784)\end{array}$ & $\begin{array}{l}-2.993 \\
(5.065)\end{array}$ & $\begin{array}{l}-63.12 \\
(304.4)\end{array}$ & $\begin{array}{l}1.378 \\
(3.517)\end{array}$ \\
\hline$\Delta$ policy rate USA & $\begin{array}{l}0.319^{\star \star *} \\
(0.0815)\end{array}$ & $\begin{array}{l}0.318^{* * *} \\
(0.0867)\end{array}$ & $\begin{array}{l}0.343^{* * *} \\
(0.0960)\end{array}$ & $\begin{array}{l}0.150 \\
(0.133)\end{array}$ & $\begin{array}{l}36.07^{* * *} \\
(9.377)\end{array}$ & $\begin{array}{l}-749.7 \\
(524.2)\end{array}$ & $\begin{array}{l}0.859 \\
(5.852)\end{array}$ \\
\hline Google Index & $\begin{array}{l}0.00199^{* * *} \\
(0.000369)\end{array}$ & $\begin{array}{l}0.00213^{* * *} \\
(0.000393)\end{array}$ & $\begin{array}{l}0.00129^{* * *} \\
(0.000424)\end{array}$ & $\begin{array}{l}0.000946 \\
(0.000610)\end{array}$ & $\begin{array}{l}0.155^{\star \star *} \\
(0.0432)\end{array}$ & $\begin{array}{l}-1.686 \\
(2.387)\end{array}$ & $\begin{array}{l}0.0785^{\star * *} \\
(0.0268)\end{array}$ \\
\hline Oxford Index & $\begin{array}{l}0.000537^{*} \\
(0.000293)\end{array}$ & $\begin{array}{l}0.000755^{\star *} \\
(0.000312)\end{array}$ & $\begin{array}{l}0.000252 \\
(0.000338)\end{array}$ & $\begin{array}{l}8.70 \mathrm{e}-05 \\
(0.000491)\end{array}$ & $\begin{array}{l}-0.0140 \\
(0.0359)\end{array}$ & $\begin{array}{l}3.393^{*} \\
(1.882)\end{array}$ & $\begin{array}{l}0.0133 \\
(0.0213)\end{array}$ \\
\hline Constant & $\begin{array}{l}-0.0390^{* *} \\
(0.0170)\end{array}$ & $\begin{array}{l}-0.0387^{\star *} \\
(0.0181)\end{array}$ & $\begin{array}{l}-0.00107 \\
(0.0204)\end{array}$ & $\begin{array}{l}0.0112 \\
(0.0287)\end{array}$ & $\begin{array}{l}-2.375 \\
(1.945)\end{array}$ & $\begin{array}{l}-66.55 \\
(107.5)\end{array}$ & $\begin{array}{l}-1.243 \\
(1.222)\end{array}$ \\
\hline Observations & 1,317 & 1,317 & 968 & 790 & 1,056 & 1,202 & 1,290 \\
\hline R-squared & 0.072 & 0.057 & 0.035 & 0.015 & 0.087 & 0.022 & 0.023 \\
\hline Number of countrycode & 15 & 15 & 11 & 9 & 12 & 14 & 15 \\
\hline $\begin{array}{l}\text { Standard errors in pare } \\
{ }^{* * *} p<0.01,{ }^{* *} p<0.05,{ }^{*}\end{array}$ & $\begin{array}{l}\text { heses } \\
0<0.1\end{array}$ & & & & & & \\
\hline
\end{tabular}

\begin{tabular}{|llllllllllll|}
\hline \multicolumn{10}{c|}{ Table IV.3. Average of Country-Specific Coefficients for the EMDE Sample } \\
\hline VARIABLES & $10 Y$ BY & $5 Y$ BY & 2 Y BY & 6 M BY & EMBI & Equities & FX & FX Risk & Corp. BY CDS \\
\hline Announce & -1.44 & -1.26 & -1.15 & 0.94 & -70.89 & 29.71 & 27.94 & 13.93 & 0.46 & -29.91 \\
VIX & 0.03 & 0.03 & 0.01 & 0.00 & 4.35 & -112.23 & 4.16 & 4.04 & 0.06 & 3.04 \\
$\Delta$ dom policy rate & 2.58 & 3.02 & 1.80 & 1.16 & -51.11 & 262.14 & -670.52 & -24.20 & -0.02 & -24.45 \\
$\Delta$ policy rate USA & -0.28 & 0.54 & 1.44 & -0.02 & -182.25 & 6730.62 & 19.30 & 62.83 & 0.04 & -82.61 \\
Google Index & 0.02 & 0.02 & 0.02 & 0.01 & 1.53 & -20.90 & 1.31 & 1.35 & 0.02 & 1.12 \\
Oxford Index & 0.01 & 0.01 & 0.01 & 0.01 & 0.14 & 49.65 & -1.65 & -0.21 & 0.01 & 0.12 \\
\hline \multicolumn{1}{l}{ Source: Staff analysis. } \\
\hline
\end{tabular}

CInternational Monetary Fund. Not for Redistribution 


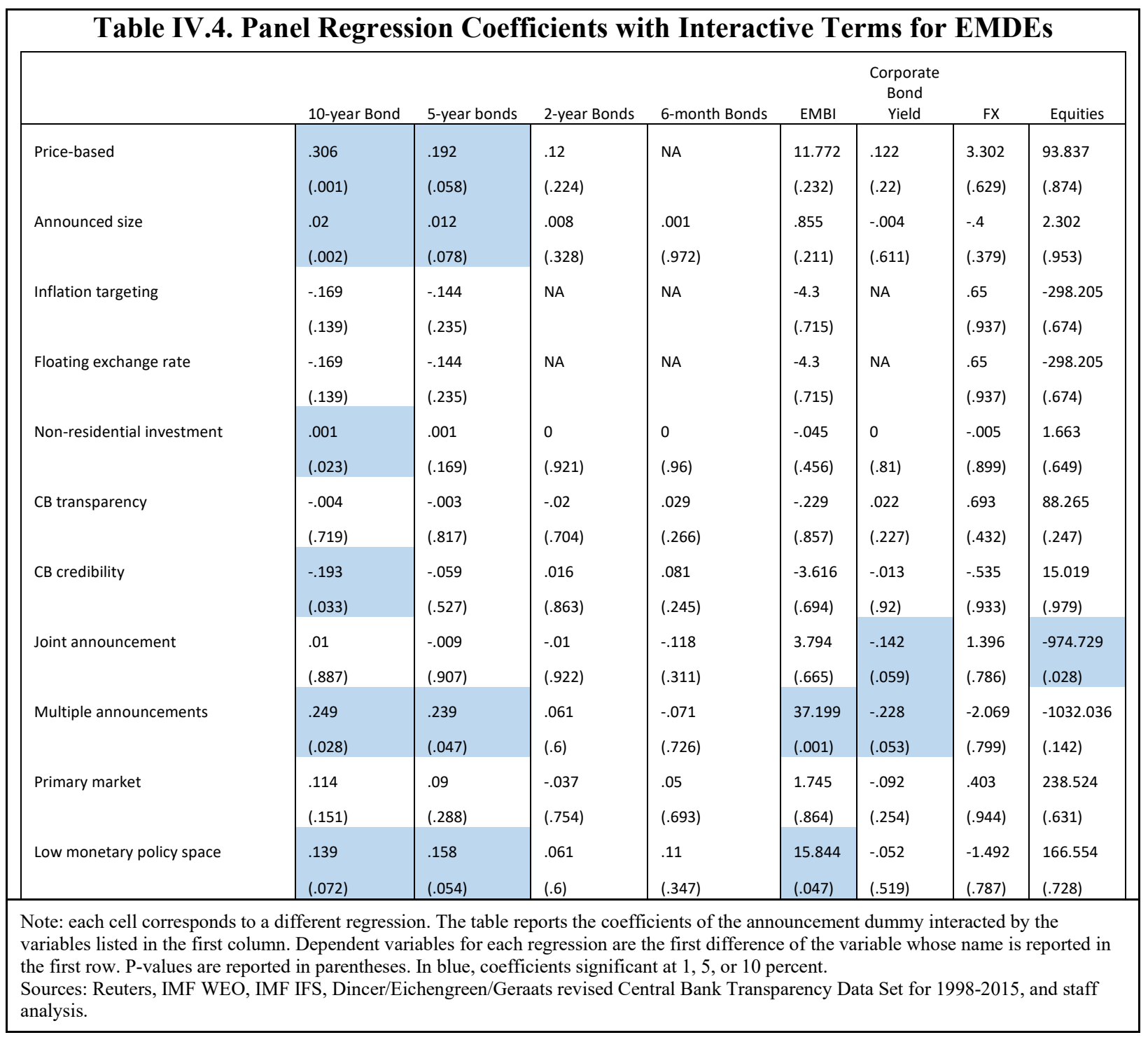




\begin{tabular}{|c|c|c|c|c|c|c|c|c|}
\hline \multicolumn{9}{|c|}{$\begin{array}{c}\text { Table IV.5. Panel Regression Coefficients with Interactive Terms for EMDEs, First } \\
\text { Announcement Only }\end{array}$} \\
\hline & 10-year Bond & 5-year Bonds & 2-year Bonds & 6-month bonds & EMBI & $\begin{array}{l}\text { Corporate } \\
\text { Bond } \\
\text { Yield }\end{array}$ & $\mathrm{FX}$ & Equities \\
\hline \multirow[t]{2}{*}{ Price-based } & .72 & .256 & .075 & NA & 32.456 & .22 & 17.377 & -252.264 \\
\hline & (0) & (.139) & (.65) & & $(.053)$ & (.194) & $(.136)$ & $(.802)$ \\
\hline \multirow[t]{2}{*}{ Announced size } & .044 & .017 & -.002 & .056 & 4.366 & -.001 & .875 & -38.436 \\
\hline & (0) & (.193) & $(.874)$ & (.42) & $(.003)$ & $(.909)$ & $(.316)$ & (.61) \\
\hline \multirow[t]{2}{*}{ Inflation targeting } & -.176 & -.069 & NA & NA & -7.123 & NA & 3.197 & -233.404 \\
\hline & $(.281)$ & $(.689)$ & & & (.671) & & $(.784)$ & $(.817)$ \\
\hline \multirow[t]{2}{*}{ Floating exchange rate } & -.176 & -.069 & NA & NA & -7.123 & NA & 3.197 & -233.404 \\
\hline & $(.281)$ & $(.689)$ & & & $(.671)$ & & $(.784)$ & $(.817)$ \\
\hline \multirow[t]{2}{*}{ Non-residential investment } & .002 & 0 & -.001 & 0 & -.16 & .001 & .094 & 5.276 \\
\hline & (.195) & $(.917)$ & (.56) & $(.991)$ & $(.318)$ & $(.541)$ & (.4) & $(.584)$ \\
\hline \multirow[t]{2}{*}{ CB transparency } & -.048 & -.045 & -.027 & -.014 & -3.608 & .01 & .811 & 188.715 \\
\hline & $(.022)$ & $(.043)$ & (.68) & (.798) & $(.095)$ & (.79) & $(.586)$ & $(.143)$ \\
\hline \multirow[t]{2}{*}{ CB credibility } & -.289 & -.205 & .041 & -.131 & -16.962 & -.11 & -5.123 & -191.267 \\
\hline & $(.042)$ & $(.16)$ & (.773) & $(.241)$ & $(.234)$ & (.588) & $(.604)$ & $(.83)$ \\
\hline \multirow[t]{2}{*}{ Joint announcement } & .156 & .226 & -.047 & .031 & 28.472 & -.237 & -2.719 & -1687.098 \\
\hline & (.139) & $(.042)$ & $(.706)$ & $(.856)$ & $(.023)$ & $(.036)$ & $(.717)$ & (.009) \\
\hline \multirow[t]{2}{*}{ Multiple announcements } & .349 & .286 & .059 & .05 & 42.593 & -.157 & .064 & -1083.069 \\
\hline & $(.004)$ & $(.027)$ & (.639) & $(.817)$ & & & & \\
\hline \multirow[t]{2}{*}{ Primary market } & -.17 & -.129 & -.138 & NA & NA & -.399 & -2.548 & 206.005 \\
\hline & $(.316)$ & (.469) & (.402) & & & $(.018)$ & (.833) & $(.844)$ \\
\hline \multirow[t]{2}{*}{ Low monetary policy space } & .075 & .013 & .059 & -.049 & 13.946 & -.129 & 1.97 & -81.39 \\
\hline & $(.477)$ & $(.908)$ & $(.639)$ & $(.772)$ & $(.204)$ & $(.251)$ & $(.793)$ & (.9) \\
\hline
\end{tabular}

Note: each cell corresponds to a different regression. The table reports the coefficients of the announcement dummy interacted by the variables listed in the first column. Dependent variables for each regression are the first difference of the variable whose name is reported in the first row. P-values are reported in parentheses. In blue, coefficients significant at 1, 5, or 10 percent.

Sources: Reuters, IMF WEO, IMF IFS, Dincer/Eichengreen/Geraats revised Central Bank Transparency Data Set for 1998-2015, and staff analysis 
Table IV.6. Panel Regression Coefficients with Interactive Terms for EMDEs and AEs

\begin{tabular}{|c|c|c|c|c|c|c|c|c|}
\hline & 10-year Bond & 5-year Bonds & 2-year bonds & 6-month Bonds & $\mathrm{FX}$ & Equities & EMBI & $\begin{array}{l}\text { Corporate } \\
\text { Bond } \\
\text { Yield }\end{array}$ \\
\hline \multicolumn{9}{|c|}{ Panel a. all announcements } \\
\hline \multirow[t]{2}{*}{ EMDES } & -.122 & -.094 & -.075 & -.026 & -2.45 & 49.96 & \multirow{6}{*}{$\begin{array}{l}-.953 \\
(.757)\end{array}$} & .029 \\
\hline & (0) & $(.002)$ & $(.037)$ & $(.608)$ & $(.238)$ & $(.781)$ & & $(.364)$ \\
\hline \multirow[t]{2}{*}{ AEs } & .014 & -.009 & .005 & .002 & -.008 & 222.503 & & \\
\hline & $(.378)$ & $(.454)$ & $(.611)$ & $(.838)$ & $(.921)$ & (0) & & \\
\hline \multirow[t]{2}{*}{ EMDEs and AEs } & -.076 & -.064 & -.043 & -.012 & -1.606 & 103.265 & & \\
\hline & (0) & $(.002)$ & $(.053)$ & $(.67)$ & $(.252)$ & $(.395)$ & & \\
\hline \multicolumn{9}{|c|}{ Panel b. first announcements } \\
\hline \multirow[t]{2}{*}{ EMDES } & -.067 & -.082 & -.083 & .08 & -.416 & 128.595 & \multirow{6}{*}{$\begin{array}{l}-1.45 \\
(.777)\end{array}$} & .118 \\
\hline & $(.16)$ & $(.103)$ & $(.115)$ & $(.318)$ & $(.903)$ & $(.662)$ & & $(.029)$ \\
\hline \multirow[t]{2}{*}{ AEs } & .103 & -.033 & -.022 & .008 & -.063 & 452.735 & & \\
\hline & $(.004)$ & (.194) & $(.337)$ & $(.705)$ & $(.727)$ & $(.001)$ & & \\
\hline \multirow[t]{2}{*}{ EMDEs and AEs } & -.03 & -.071 & -.073 & .059 & -.272 & 187.865 & & \\
\hline & $(.401)$ & $(.056)$ & $(.055)$ & $(.258)$ & $(.913)$ & $(.383)$ & & \\
\hline \multicolumn{9}{|c|}{ Panel c. implementation } \\
\hline \multirow[t]{2}{*}{ EMDES } & -.044 & -.023 & .007 & -.007 & 1.14 & 195.238 & \multirow{6}{*}{$\begin{array}{l}-1.018 \\
(.746)\end{array}$} & -.045 \\
\hline & $(.114)$ & $(.433)$ & $(.85)$ & $(.929)$ & $(.564)$ & $(.253)$ & & $(.141)$ \\
\hline \multirow[t]{2}{*}{ AEs } & -.007 & -.003 & .005 & .005 & .002 & 51.772 & & \\
\hline & $(.373)$ & $(.56)$ & $(.337)$ & (.168) & $(.961)$ & (.069) & & \\
\hline \multirow[t]{2}{*}{ EMDEs and AEs } & -.01 & -.001 & .015 & .015 & .928 & 44 & & \\
\hline & $(.434)$ & $(.927)$ & $(.308)$ & $(.433)$ & $(.298)$ & $(.569)$ & & \\
\hline
\end{tabular}

Note: each cell corresponds to a different regression. The table reports the coefficients of the announcement dummy interacted by the variables listed in the first column. Dependent variables for each regression are the first difference of the variable whose name is reported in the first row. Panel a reports results for all announcements. Panel b reports results only for the first announcement for each country. Panel c reports result on the date of implementation. P-values are reported in parentheses. Indonesia has been excluded. P-values are reported in parentheses. In blue, coefficients significant at 1, 5, or 10 percent.

Sources: Reuters and staff analysis. 


\section{Annex V. Literature Review}

\begin{tabular}{|c|c|c|c|c|c|c|}
\hline Title & Authors & Methodology & Main findings & Variables & Sample & Period \\
\hline \multirow[t]{2}{*}{$\begin{array}{l}\text { "Unconventional } \\
\text { Monetary Policy in a } \\
\text { Small Open Economy" } \\
\text { IMF working paper } \\
17 / 268\end{array}$} & $\begin{array}{l}\text { Margaux } \\
\text { MacDonald and } \\
\text { Michat Ksawery } \\
\text { Popiel }\end{array}$ & $\begin{array}{l}\text { Event study } \\
\text { method }\end{array}$ & $\begin{array}{l}\text { Show that two of the three main ZLB } \\
\text { announcements by the Bank of Canada } \\
\text { were associated with tail events in } \\
\text { changes in the shadow short rate. The tail } \\
\text { event is defined as a statistically } \\
\text { significant change in the shadow rate } \\
\text { (based on one-day changes) based on } \\
\text { standard errors calculated assuming a } \\
\text { normal distribution. }\end{array}$ & $\begin{array}{l}\text { Shadow interest rate and } \\
\text { Bank of Canada policy } \\
\text { announcements. }\end{array}$ & Canada & $2009-2010$ \\
\hline & & B-SVAR model & $\begin{array}{l}\text { During the ZLB period, on average, } \\
\text { Canadian unconventional monetary policy } \\
\text { increased output by 0.13 percent, while } \\
\text { US uncoonventional monetary policy } \\
\text { increased Canadian output by } 1.2 \\
\text { percent on average. Results demonstrate } \\
\text { the effectiveness of domestic } \\
\text { unconventional monetary policy and the } \\
\text { strong spillovers from foreign } \\
\text { unconventional monetary policy in a small } \\
\text { open economy. }\end{array}$ & $\begin{array}{l}\text { Canada: policy rate, } \\
\text { exchange rate, } \\
\text { seasonally-adjusted real } \\
\text { industrial production, } \\
\text { consumer price index, } \\
\text { seasonally adjusted real } \\
\text { exports, and seasonally } \\
\text { adjusted real imports. } \\
\text { US: policy rate r; the } \\
\text { implied volatility of the } \\
\text { S\&P } 500 \text { index, } \\
\text { commodity export prices, } \\
\text { consumer price index, } \\
\text { seasonally-adjusted real } \\
\text { industrial production } \\
\text { shadow rates for Canada } \\
\text { and the US. }\end{array}$ & $\begin{array}{l}\text { Canada and } \\
\text { us }\end{array}$ & August 1994- Dec 2016 (monthly) \\
\hline $\begin{array}{l}\text { "Unconventional } \\
\text { Monetary Policy and } \\
\text { Asset price Risk" IMF } \\
\text { Working Paper 13/190 }\end{array}$ & $\begin{array}{l}\text { Shaun K. } \\
\text { Roache and } \\
\text { Marina V. } \\
\text { Rousset }\end{array}$ & $\begin{array}{l}\text { Event study } \\
\text { method }\end{array}$ & $\begin{array}{l}\text { Find that "tail risk" diminishes in the } \\
\text { immediate aftermath of UMP } \\
\text { events, particularly downside left tail risk. }\end{array}$ & $\begin{array}{l}\text { Estimate risk neutral } \\
\text { density functions from } \\
\text { options prices: the euro } \\
\text { - U.S. dollar exchange } \\
\text { rate, the S\&P50O equity } \\
\text { index, and the prices of } \\
\text { five commodities: gold, } \\
\text { crude oil, natural gas, } \\
\text { corn, and soybeans }\end{array}$ & us & $\begin{array}{l}\text { Daily frequency with a horizon of } 3 \\
\text { months }\end{array}$ \\
\hline \multirow[t]{2}{*}{$\begin{array}{l}\text { "An Event Study of } \\
\text { Covid-19 Central Bank } \\
\text { Quantitative Easing" } \\
\text { NBER Working Paper } \\
27339\end{array}$} & $\begin{array}{l}\text { Jonathan S. } \\
\text { Hartley } \\
\text { Alessandro } \\
\text { Rebucci }\end{array}$ & Event study method & $\begin{array}{l}\text { d The average developed market } Q E \\
\text { announcement had a statistically } \\
\text { significant }-0.14 \% 1 \text {-day impact, which is } \\
\text { slightly smaller than past interventions } \\
\text { during the Great Recession era. }\end{array}$ & $\begin{array}{l}\text { 10-year bond yield and } \\
\text { asset purchase program } \\
\text { announcements }\end{array}$ & $\begin{array}{l}\text { Developed } \\
\text { markets }\end{array}$ & March-April 2020 \\
\hline & & & $\begin{array}{l}\text { The average impact of emerging market } \\
\text { QE announcements was significantly } \\
\text { larger, averaging -0.28\%and -0.43\% over } \\
\text { 1-day and 3-day windows, respectively. }\end{array}$ & & $\begin{array}{l}\text { Emerging } \\
\text { markets }\end{array}$ & \\
\hline $\begin{array}{l}\text { The Effectiveness of } \\
\text { Unconventional } \\
\text { Monetary Policy at the } \\
\text { Zero Lower Bound: } A \\
\text { Cross-Country Analysis }\end{array}$ & $\begin{array}{l}\text { Leonardo } \\
\text { Gambacorta } \\
\text { Boris Hofmann } \\
\text { Gert Peersman }\end{array}$ & Panel VAR & $\begin{array}{l}\text { Find that an exogenous increase in } \\
\text { central bank balance sheets at the zero } \\
\text { lower bound leads to a temporary rise in } \\
\text { economic activity and consumer } \\
\text { prices. Individual country results suggest } \\
\text { that there are no major differences in the } \\
\text { macroeconomic effects of unconventional } \\
\text { monetary policies across countries, } \\
\text { despite the heterogeneity of the } \\
\text { measures that were taken. }\end{array}$ & $\begin{array}{l}\text { Vector of endogenous } \\
\text { variables: the log of } \\
\text { seasonally adjusted real } \\
\text { GDP, the log seasonally } \\
\text { adjusted consumer price } \\
\text { index, the log level of } \\
\text { seasonally adjusted } \\
\text { central bank assets, and } \\
\text { the level of implied stock } \\
\text { market volatility (VIX) of } \\
\text { the national stock market } \\
\text { index. Central bank } \\
\text { assets represent the } \\
\text { (unconventional) } \\
\text { monetary policy } \\
\text { instrument while policy } \\
\text { rates are not included in } \\
\text { the benchmark model. }\end{array}$ & $8 \mathrm{AE}$ & $\begin{array}{l}\text { Monthly day } \\
\text { Jan 2008-June } 2011\end{array}$ \\
\hline $\begin{array}{l}\text { The Liquidity Effects of } \\
\text { Official Bond Market } \\
\text { Intervention }\end{array}$ & $\begin{array}{l}\text { Michiel De } \\
\text { Pooter, } \\
\text { Robert F. Martin, } \\
\text { and Seth Pruitt }\end{array}$ & $\begin{array}{l}\text { Ordinary least } \\
\text { squares (OLS) } \\
\text { and } \\
\text { (feasible) } \\
\text { generalized least } \\
\text { squares (GLS) } \\
\text { using panel data }\end{array}$ & $\begin{array}{l}\text { From reduced-form estimates, we find } \\
\text { robust, economically significant impact } \\
\text { and lasting reductions in sovereign } \\
\text { bonds' liquidity premia in response to } \\
\text { official purchases. }\end{array}$ & $\begin{array}{l}\text { From our data on bond } \\
\text { yields and CDS spreads, } \\
\text { we construct a measure } \\
\text { of bond liquidity akin to } \\
\text { the well-known CDS- } \\
\text { bond basis, which is } \\
\text { defined as } \\
\text { a country's CDS spread } \\
\text { minus the spread of its } \\
\text { corresponding sovereign } \\
\text { yield over the yield on a } \\
\text { German bond, all of } \\
\text { comparable maturity. }\end{array}$ & $\begin{array}{l}\text { Portugal, } \\
\text { Ireland, Italy, } \\
\text { and Spain }\end{array}$ & Jan. 2010-Mar. 2012 \\
\hline $\begin{array}{l}\text { Measuring the } \\
\text { Macroeconomic Impact } \\
\text { of Monetary Policy } \\
\text { at the Zero Lower } \\
\text { Bound }\end{array}$ & Wu and Xia (2016 & 6 Factor-augmented ' & $\begin{array}{l}\text { Use their U.S. Shadow rate in a factor- } \\
\text { augmented VAR to show that } \\
\text { macroeconomic effects of an } \\
\text { unanticipated change in the policy } \\
\text { instrument, identified through timing } \\
\text { restrictions, are similar to the pre-ELB } \\
\text { period, where the federal funds rate is the } \\
\text { policy instrument. A counterfactual } \\
\text { exercise for the ELB period (2009-2013) } \\
\text { shows that Fed UMP had non-trivial } \\
\text { effects, reducing the unemployment rate } \\
\text { by } 1 \% \text { at peak. }\end{array}$ & Shadow rate & us & Jan 1990-Dec 2013 \\
\hline $\begin{array}{l}\text { Spillovers from the } \\
\text { ECB's nonstandard } \\
\text { monetary policies on } \\
\text { non-euro area EU } \\
\text { countries: } \\
\text { evidence from an event- } \\
\text { study } \\
\text { analysis }\end{array}$ & $\begin{array}{l}\text { Matteo } \\
\text { Falagiarda, } \\
\text { Peter McQuade } \\
\text { and Marcel } \\
\text { Tirpák }\end{array}$ & $\begin{array}{l}\text { Event study } \\
\text { method }\end{array}$ & $\begin{array}{l}\text { Find strong evidence of spillover effects } \\
\text { from the ECB's announcements on bond } \\
\text { yields. We also find that the SMP } \\
\text { announcements resulted in significant } \\
\text { spillovers, while those from the OMT and } \\
\text { the PSPP announcements were rather } \\
\text { limited. Turning to the transmission } \\
\text { channels, we argue that spillovers from } \\
\text { the SMP announcements went through } \\
\text { the portfolio rebalancing and the signaling } \\
\text { channels. The transmission of the OMT } \\
\text { operated via the confidence channel and } \\
\text { for the PSPP we find evidence that both } \\
\text { the confidence and the signaling } \\
\text { channels were at play. }\end{array}$ & $\begin{array}{l}\text { Exchange rate vis-à-vis } \\
\text { the euro, stock market } \\
\text { index, 3-month interbank } \\
\text { rate, medium- and long- } \\
\text { term sovereign bond } \\
\text { yields, yields of } \\
\text { sovereign bonds } \\
\text { denominated in foreign } \\
\text { currency, } 17 \text { 5- and 10- } \\
\text { year CDS spread. }\end{array}$ & $\begin{array}{l}\text { Czech } \\
\text { Republic, } \\
\text { Hungary, } \\
\text { Poland } \\
\text { and Romania }\end{array}$ & $\begin{array}{l}2007-2015 \\
\text { using daily data }\end{array}$ \\
\hline
\end{tabular}




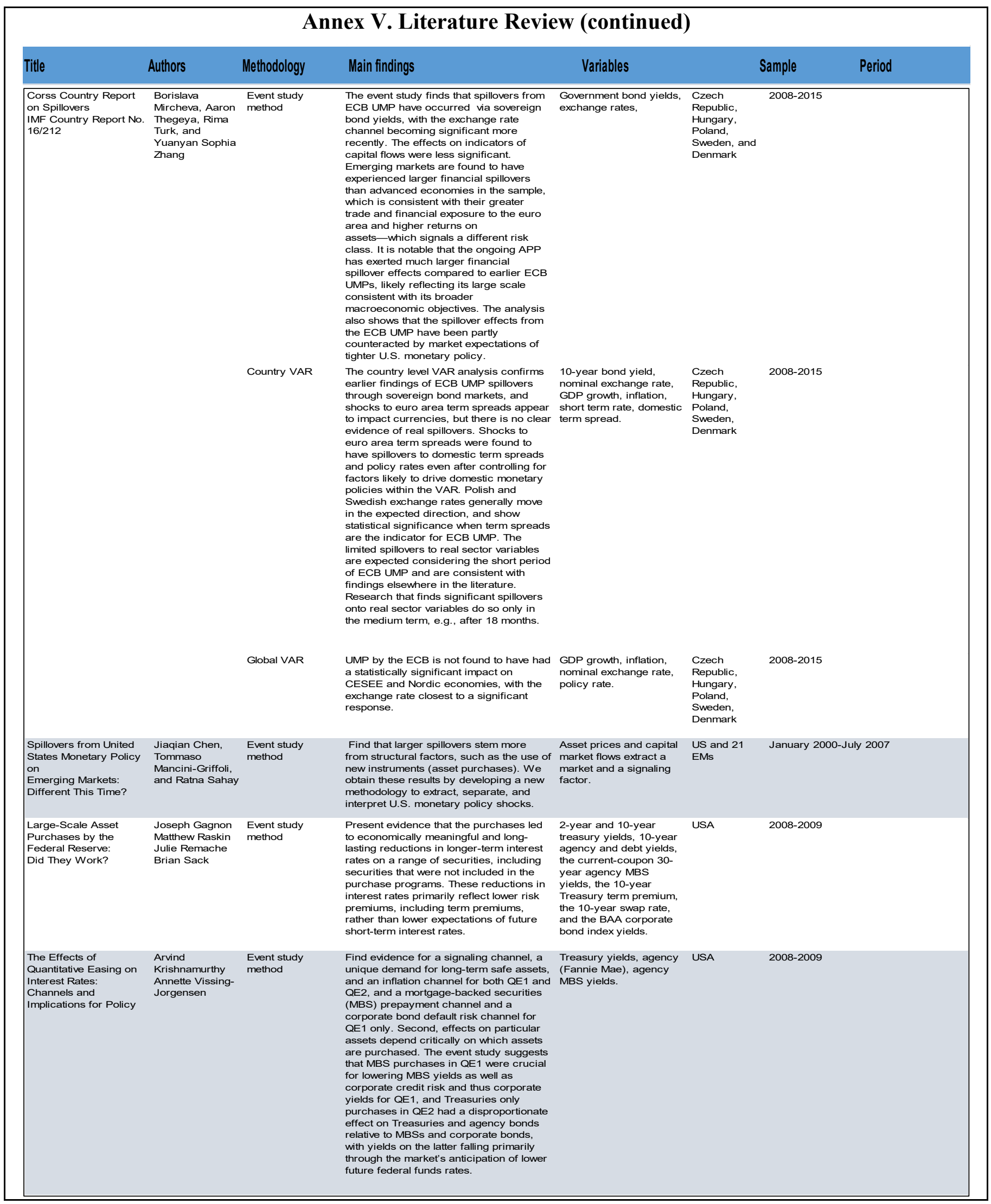




\begin{tabular}{|c|c|c|c|c|c|c|}
\hline \multicolumn{7}{|c|}{ Annex V. Literature Review (concluded) } \\
\hline Title & Authors & Methodology & Main findings & Variables & & Sample \\
\hline \begin{tabular}{|l} 
Let's Twist Again: A \\
High-Frequency \\
Event-Study Analysis of \\
Operation Twist \\
and Its Implications for \\
QE2
\end{tabular} & Eric Swanson & $\begin{array}{l}\text { Event study } \\
\text { method }\end{array}$ & $\begin{array}{l}\text { Shows that Operation Twist and QE2 are } \\
\text { similar in magnitude. It then identifies six } \\
\text { significant, discrete announcements in } \\
\text { the course of Operation Twist that could } \\
\text { have had a major effect on financial } \\
\text { markets and shows that four did have } \\
\text { statisticallly significant effects. The } \\
\text { cumulative effect of these six } \\
\text { announcements on longer-term Treasury } \\
\text { yields is highly statistically significant but } \\
\text { moderate, amounting to about } 15 \text { basis } \\
\text { points (bp). This estimate is consistent } \\
\text { both with time-series analysis undertaken } \\
\text { not long after the event and with the lower } \\
\text { end of empirical estimates of Treasury } \\
\text { supply effects in the literature. The } \\
\text { effects of Operation Twist on long-term } \\
\text { agency and corporate bond yields are } \\
\text { also statistically significant but smaller, } \\
\text { about } 13 \text { bp for agency securities and } 2 \\
\text { to } 4 \text { bp for corporates. Thus, the effects } \\
\text { of Operation Twist seem to diminish } \\
\text { substantially as one moves from Treasury } \\
\text { securities toward private sector credit } \\
\text { instruments. }\end{array}$ & $\begin{array}{l}\text { Treasury yields (3- } \\
\text { month, 1-year, 2-year, } \\
5 \text {-year, 10-year, 30- } \\
\text { year), agency and } \\
\text { corporate bonds. }\end{array}$ & USA & $2008-2009$ \\
\hline $\begin{array}{l}\text { What are the } \\
\text { macroeconomic effects } \\
\text { of asset purchases }\end{array}$ & $\begin{array}{l}\text { Martin Weale } \\
\text { Tomasz Wieladek }\end{array}$ & B-VAR & $\begin{array}{l}\text { An asset purchase announcement of } 1 \% \\
\text { of GDP leads to a statistically significant } \\
\text { rise of } 0.58 \%(0.25 \%) \text { and } 0.62 \% \\
(0.32 \%) \text { rise in real GDP and CPI for the } \\
\text { US (UK). The transmission channels } \\
\text { differ in the two countries. }\end{array}$ & $\begin{array}{l}\text { Real GDP and CPI, } \\
\text { government bonds }\end{array}$ & UK and US & \\
\hline $\begin{array}{l}\text { An event-study analysis } \\
\text { of ECB balance sheet } \\
\text { policies since October } \\
2008 \text { EC ECONOMIC } \\
\text { BRIEF 001 | JULY } 2015\end{array}$ & $\begin{array}{l}\text { Lucian Briciu } \\
\text { Giulio Lisi } \\
5\end{array}$ & $\begin{array}{l}\text { Event study } \\
\text { method }\end{array}$ & $\begin{array}{l}\text { The set of ECB BSPs announced in } 2014 \\
\text { had the broadest immediate impact on } \\
\text { euro area financial conditions, though } \\
\text { possibly augmented by parallel } \\
\text { announcements of conventional monetary } \\
\text { policy decisions. The expanded asset } \\
\text { purchase programme (EAPP) had the } \\
\text { strongest impact on the exchange rate, } \\
\text { while also significantly lowering longer- } \\
\text { term government bond yields. The } \\
\text { Securities Markets Programme (SMP), }\end{array}$ & $\begin{array}{l}\text { 2-year bond yields, 10- } \\
\text { year bond yields, } \\
\text { exchange rate, } \\
\text { equity market indices. }\end{array}$ & Euro Area & Oct 2008-Jan 2015 \\
\hline
\end{tabular}




\section{REFERENCES}

Altavilla, C., D. Giannone, and M. Lenza, 2013. "The Financial and Macroeconomic Effects of OMT Announcements,” ECB Working Paper Series No. 1707.

Arslan, Y., M. Drehmann, and B. Hoffman, 2020. "Central Bank Bond Purchases in Emerging Market Economies,” BIS Bulletin No. 20.

Briciu, L., and G. Lisi ,2015. ” An Event-Study Analysis of ECB Balance Sheet Policies Since October 2008," European Economy, Economic Brief 001.

Chen, J., T. Mancini-Griffoli, and R. Sahay, 2014.” Spillovers from United States Monetary Policy on Emerging Markets: Different This Time?” IMF Working Paper No. 14/240 (Washington: International Monetary Fund)

De Pooter, M., R. F. Martin, and S. Pruitt, 2018. “The Liquidity Effects of Official Bond Market Intervention", Journal of Financial and Quantitative Analysis, Vol 53, No 1, Feb 2018

Falagiarda, M., P. McQuade, and M. Tirpak, 2015. “Spillovers from the ECB's Nonstandard Monetary Policies on Non-Euro Area EU Countries: Evidence from an Event-Study Analysis," ECB Working Paper Series No. 1869

Gagnon, J., M. Raskin, J. Remache, B. P. Sack, 2011. "Large-Scale Asset Purchases by the Federal Reserve: Did They Work?", International Journal of Central Banking, Vol. 7, No1. pp. 3-41

Gambacorta, L., B. Briciu, and G. Peersman, 2013. "The Effectiveness of Unconventional Monetary Policy at the Zero Lower Bound: A Cross-Country Analysis"

Hartley, J. and A. Rebucci, 2020. "An Event Study of Covid-19 Central Bank QE in Advanced and Emerging Economies," NBER Working Paper No. 27339.

International Monetary Fund, 2013. "Global Impact and Challenges of Unconventional Monetary Policies," Monetary and Capital Markets/Strategy and Policy Review Departments, IMF Policy Paper, October 18 (Washington)

International Monetary Fund, 2016. "Cross Country Report on Spillovers”, IMF Country Report No 16/212

Jordà, Ò., 2005. "Estimation and inference of impulse responses by local projections", American Economic Review, vol 95, no 1, pp 161-82

MacDonald, M., and M. K. Popiel, 2017. "Unconventional Monetary Policy in a Small Open Economy”, IMF Working Paper 17/268 
Rai, V., and L. Suchanek, 2014. "The Effect of the Federal Reserve's Tapering Announcements on Emerging Markets," Bank of Canada Staff Working Paper 2014-50

Sever, C., R. Goel, D. Drakopoulos, and E. Papageorgiou, 2020 " Effects of Emerging Market Asset Purchase Program Announcements on Financial Markets During the COVID19 Pandemic.” IMF Working Paper 20/292

Swanson, Eric T., 2011. "Let's Twist Again: A High-Frequency Event-Study Analysis of Operation Twist and Its Implications for QE2", Brookings Papers on Economic Activity, Spring 2011

Vissing-Jorgensen, A. and A. Krishnamurthy, 2011. "The Effects of Quantitative Easing on Interest Rates: Channels and Implications for Policy”, Brookings Papers on Economic Activity, Fall 2011. Pp. 215-265

Weale, M. and T. Wieladek. 2016. "What Are the Macroeconomic Effects of Asset Purchases?" Journal of Monetary Economics 79: 81-93. 